AROUEOLOGía Y SOCIEDAD

№ 26, 2014: 153-192

ISSN: 0254-8062

\title{
ESTUDIO ARQUEOLÓGICO SOBRE LOS GUANCAS Y TARAMAS. UN NUEVO ANÁLISIS SOBRE EL DESARROLLO ECONÓMICOY SOCIAL DE ESTAS CULTURAS EN LOS ANDES CENTRALES
}

\author{
IRVIN NAVARRO AMARO \\ UNIVERSIDAD NACIONAL MAYOR DE SAN MARCOS \\ i.navarro.arq@hotmail.com
}

\section{RESUMEN}

En este artículo realizamos un estudio arqueológico sobre los guancas y taramas pre-Tawantinsuyo, en el cual analizamos sus aspectos económicos y sociales. En el marco de esta investigación nos enfocamos en estudiar el desarrollo agrícola y ganadero de estas culturas en relación a los Andes centrales y también analizamos la organización social de estas culturas. Todo esto en base a los datos arqueológicos que registramos durante nuestras prospecciones y excavaciones arqueológicas. En este trabajo exponemos nuestras teorías sobre el desarrollo económico y social de los guancas y taramas, las cuales formulamos en base a nuestros datos arqueológicos; dentro de este punto también realizamos unas críticas hacia las teorías que propusieron Upper Mantaro Research Project (UMARP) y Parsons para explicar la organización social y economía de los guancas y taramas respectivamente. Además realizamos un breve estudio sobre la actividad funeraria Guanca y Tarama, el cual ha sido un tema poco estudiado hasta el momento.

PALABRAS ClAVE: Andes centrales, actividad agropecuaria, región quechua, región puna, agricultura, ganadería, organización social, sistema colectivo.

\begin{abstract}
In this paper we carry out a comprehensive archaeological study on the Pre-Tawantinsuyo guancas and taramas, focusing on their economic and social development. For this purpose, we performed methodical archaeological surveys and excavations, which gave us much empirical evidence. The description and analysis of this data helped us to better understand these cultures in relation to the Central Andes. Therefore, on this basis, we propose new theories that better explain the economic and social development of Guancas and taramas, likewise, we present a critique of the theories previously proposed by Parsons and the Upper Mantaro Research Project (UMARP). Furthermore, in this paper, we conduct a brief study on the funerary activities of the Guanca and Tarama, a subject little studied so far.
\end{abstract}

KEYwords: Central Andes, farming and livestock activities, Quechua region, Puna region, economic production, social organization 
El estudio arqueológico sobre los guancas y taramas pre-Tawantinsuyo, ha sido durante mucho tiempo una deuda que la arqueología peruana ha tenido pendiente. Pues desde las investigaciones llevadas a cabo por el grupo UMARP (Earle 1978, 1987, 2001) para el caso de los guancas, y desde los estudios realizados por Parsons $(1978,2000,2004)$ en el territorio Tarama, ambas en las décadas de 1970-80 del siglo pasado, no se han realizado nuevas investigaciones que propongan novedosas teorías sobre el desarrollo económico y social de estas dos culturas. En los años siguientes, investigadores nacionales y extranjeros han continuado con el análisis a estas culturas y han seguido apoyando las teorías propuestas por UMARP y Parsons. Esto nos demuestra que durante ese tiempo no hubo un claro sentido crítico hacia estas propuestas.

Al finalizar el análisis crítico de toda la bibliografía referente al tema de los guancas y taramas, hemos observado que las teorías propuestas por UMARP (Earle 1978, 1987, 2001) y Parsons (1978, 2000, 2004), formuladas para explicar el desarrollo económico y social de los guancas y taramas, respectivamente, presentan contradicciones; pues existen evidentes datos que no ayudan al firme sustento de sus teorías. Debido a esto, decidimos realizar nuestra propia investigación, con el objetivo de poder estudiar y proponer nuevas teorías que ayuden a comprender mejor el desarrollo económico y social de los guancas y taramas en relación a los Andes centrales. Para lo cual, realizamos prospecciones arqueológicas en todas las regiones que ocuparon estas culturas, en el actual departamento de Junín. Además ejecutamos excavaciones arqueológicas en el sitio Guanca de Anjushmarca, ubicado en la región de Lomo Largo, en plena área fronteriza de las provincias de Jauja y Tarma.

En este trabajo, exponemos todos los datos empíricos que registramos durante nuestras prospecciones y excavaciones arqueológicas, así mismo el análisis de éstas. También sustentamos nuestras propuestas teóricas sobre el desarrollo agrícola, ganadero y social de los guancas y taramas; además dentro de este último punto, realizamos una discusión sobre estos temas y formulamos unas críticas hacia las teorías planteadas por UMARP (Earle 1978, 1987, 2001) y Parsons (1978, 2000, 2004). Todo este estudio lo presentamos en este trabajo para el conocimiento general.

\section{ANÁLISIS DEL TERRITORIO GUANCA Y TARAMA}

La población guanca y tarama pre-Tawantinsuyo, se asentó en el actual departamento de Junín. Los guancas ocuparon los valles del Mantaro, Yanamarca, Cunas, Ricrán y las punas de Lomo Largo. Mientras que los taramas se asentaron en los valles del río Tarma, Palcamayo, Tapo y en las regiones actuales de Huasa Huasi, La Unión Leticia y San Pedro de Cajas. Los territorios ocupados por los guancas y taramas se caracterizan por presentar amplios y profundos valles, pronunciadas y angostas quebradas, y también áreas de puna. Esta caprichosa geografía, genera en esta parte de los Andes centrales, la presencia continua de ecoregiones de puna y quechua.

Es importante señalar, que el paso de una región quechua a una de puna o viceversa, en esta región de los Andes centrales es muy fácil, nosotros lo comprobamos durante nuestras prospecciones. En esta área centroandina observamos que las distancias entre cada región quechua y puna, no superan los tres kilómetros de distancia, el cual es un tramo corto para el hombre andino. Si para nosotros, durante las prospecciones que realizamos, nos pareció una distancia pequeña, imagínense lo fácil que habría sido para los guancas y taramas de ese tiempo transitar por estas dos eco-regiones tan ricas en recursos naturales.

Ahora que ya conocemos cómo se presenta el territorio ocupado por los guancas y taramas. Podemos pasar a exponer los datos arqueológicos que registramos durante nuestras prospecciones, pues este reconocimiento geográfico nos permitirá comprender mejor el desarrollo agrícola y ganadero que tuvieron estas dos culturas. 


\section{Prospecciones ARQUeOLÓGICAS}

En esta etapa de nuestra investigación registramos muchos sitios arqueológicos guancas y taramas, pero en este trabajo solo expondremos el estudio de cinco asentamientos guancas y cinco taramas. En los cuales pudimos registrar mucha evidencia arqueológica, la cual fue muy importante para poder comprender la actividad económica y social de estas culturas centroandinas. En este punto también expondremos los lasos de interacción que se desarrollaron entre los distintos asentamientos, teniendo en cuenta su área geográfica.

\section{SITIO ARQUEOLÓGICO ANJUSHMARCA}

Este asentamiento guanca se ubica en el extremo norte de la región de Lomo Largo, en plena área fronteriza de las provincias de Tarma y Jauja. Debido a las observaciones de la cerámica de superficie y al análisis arquitectónico del sitio, hemos podido determinar que Anjushmarca tuvo ocupación guanca, aunque se ubique actualmente dentro de la jurisdicción distrital de Huaricolca en la provincia de Tarma.

Anjushmarca está asentada sobre dos lomadas rocosas a $4280 \mathrm{msnm}$. Este sitio cuenta con un relieve muy accidentado, debido a esto el sitio presenta un ordenado sistema de terrazas que ayudan a generar buenas bases para las construcciones de los edificios y a producir pasajes de comunicación. En este asentamiento podemos apreciar complejos arquitectónicos guancas de tres o cuatro edificios habitacionales de plantas circular, asociados a patios de formas ovaladas. Los edificios habitacionales de planta circular miden entre 4 y $5 \mathrm{~m}$ de diámetro y pueden llegar a medir hasta 2,50 $\mathrm{m}$ de alto, los accesos de estos edificios son de forma semitrapezoidal y son muy estrechos. Además debemos mencionar que las construcciones en Anjushmarca fueron hechas con roca caliza y usaron la arcilla calcárea como mortero.

El análisis superficial en el sitio nos ha ayudado a detectar diversas manifestaciones funerarias, llegando a identificar basamentos de edificios funerarios de planta cuadrangular con pequeñas cámaras internas, también observamos edificios funerarios con base circular y osarios de base rectangular.

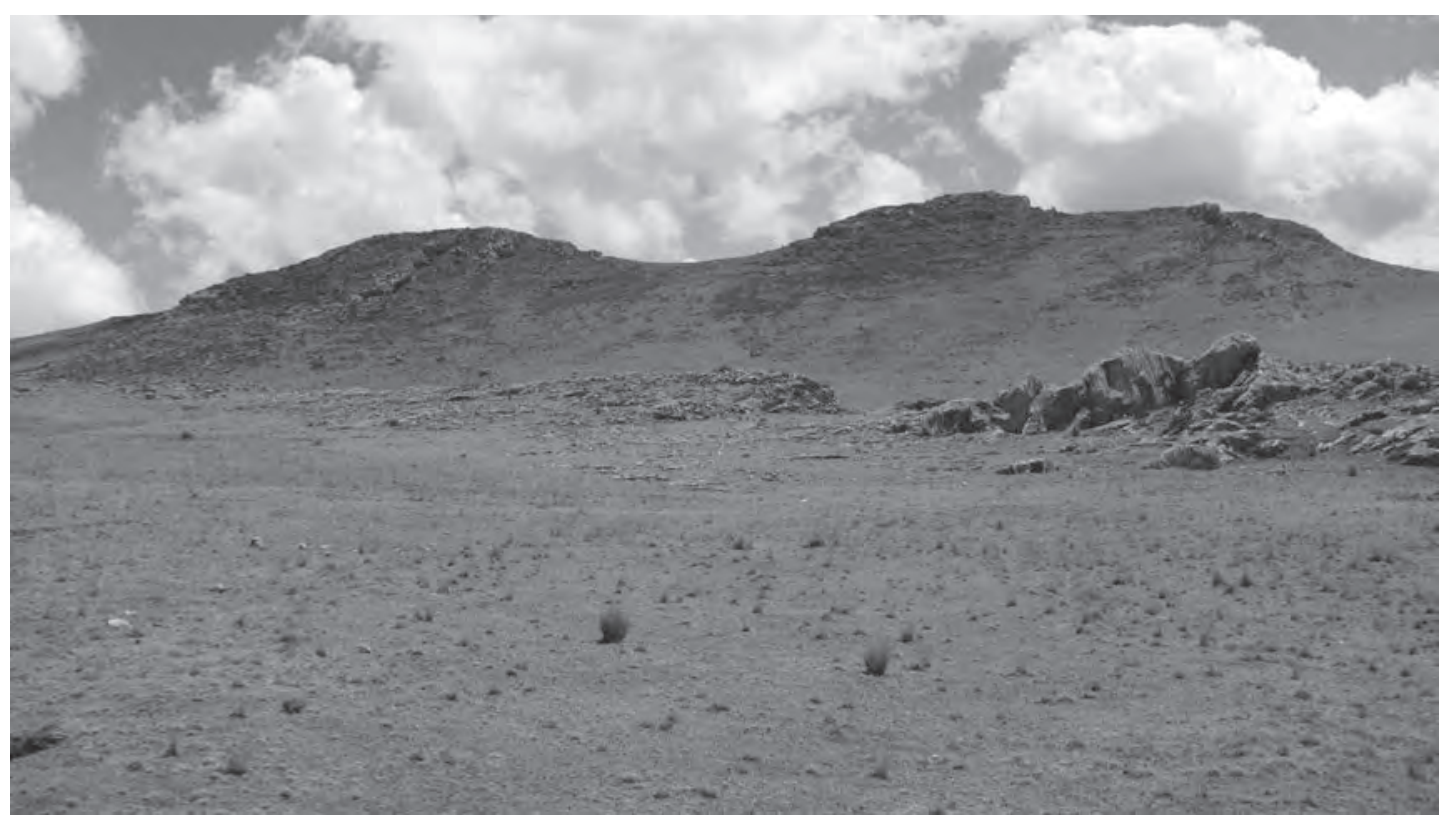

Figura 1. Vista panorámica de Anjushmarca. 


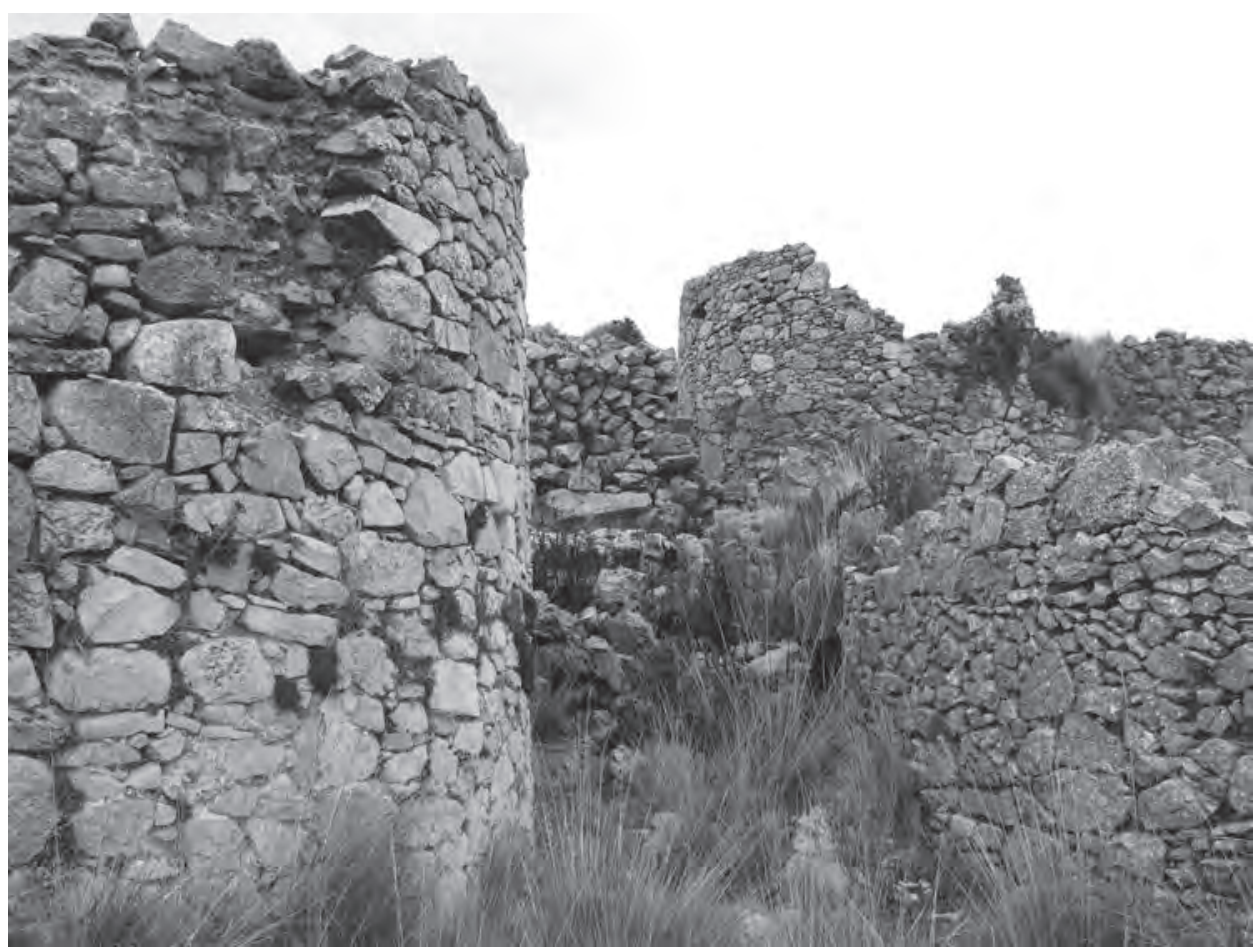

Figura 2. Vista de los edificios de planta circular de Anjushmarca.

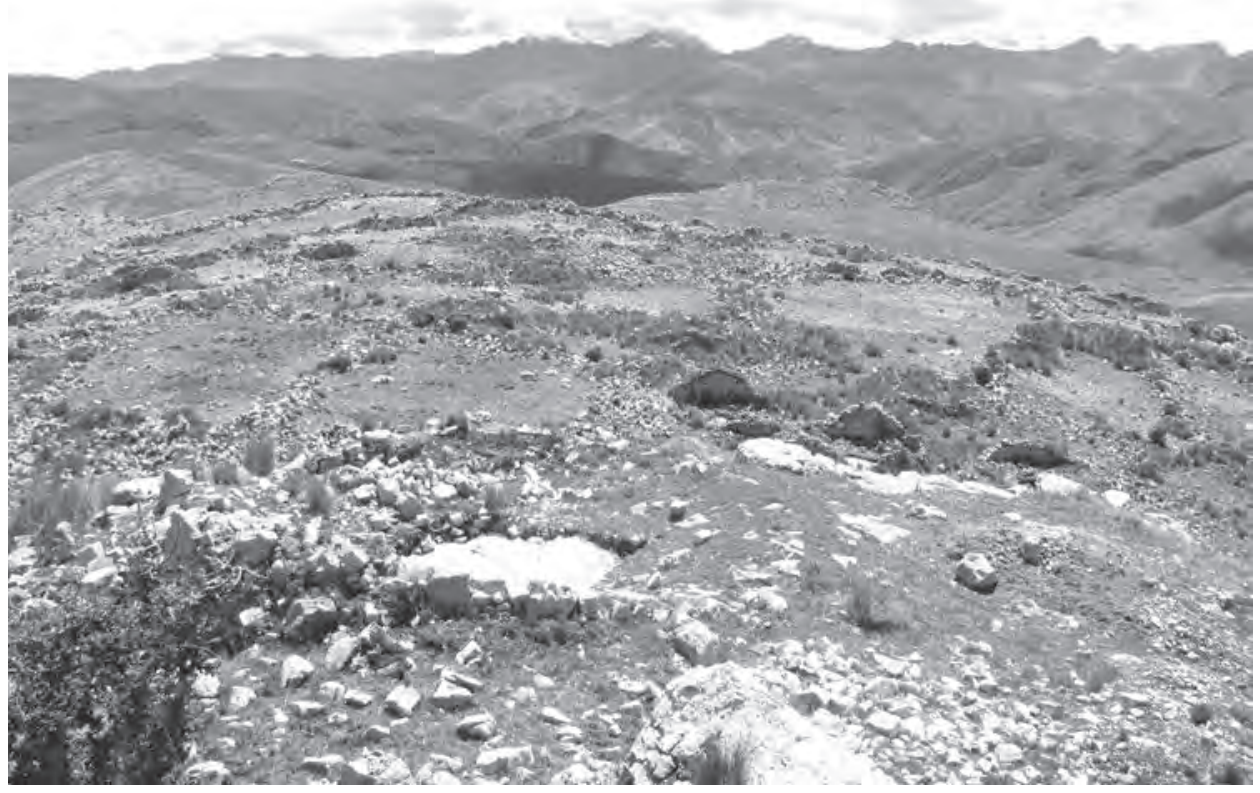

Figura 3. Vista panorámica de los complejos arquitectónicos de Anjushmarca. 
Además identificamos áreas funerarias en las bases de los peñascos de las dos colinas de Anjushmarca; en estas zonas hallamos evidencia arqueológica funeraria como material óseo humano y material constructivo derruido, lo cual nos indica que los guancas destinaron las bases de estas formaciones rocosas para sus actividades funerarias.

Anjushmarca también presenta un ordenado sistema de corrales, estos poseen una extensión de 30 y $40 \mathrm{~m}$ de diámetro, dichos corrales tienen formas ovaladas y cuadrangulares y entre ellas existen algunos edificios habitacionales. La gran cantidad de estos corrales nos indica que los pobladores de este asentamiento tuvieron una intensa actividad ganadera. La cual estuvo respaldad por los recursos naturales que presenta la puna de Lomo Largo, la cual presenta abundantes pastizales y bofedales.

La agricultura también fue una actividad productiva que desarrollaron los pobladores de Anjushmarca, pues a un kilómetro hacia el norte se encuentran fértiles tierras de cultivo, en las cuales se pueden llevar a cabo la agricultura de altura, pues estas se encuentran a más de $4000 \mathrm{msnm}$. Anjushmarca no sólo cuenta con estas tierras para el agro, ya que a dos kilómetros al norte y al este del sitio se encuentran las quebradas de Cruzhujhuan, Licuhuichay y Tranquilla, en la cuales se producen productos agrícolas de la región quechua.

Anjushmarca se habría relacionado con el sitio de Marcahasha, el cual se ubica a cuatro kilómetros al sur de Anjushmarca, en la misma región de Lomo Largo. También pudieron relacionarse con los

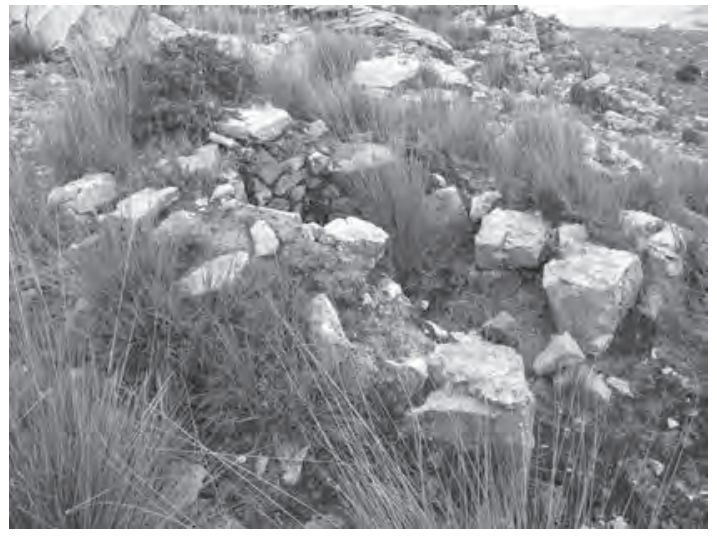

Figura 4. Vista del Osario ubicado al oeste de Anjushmarca.

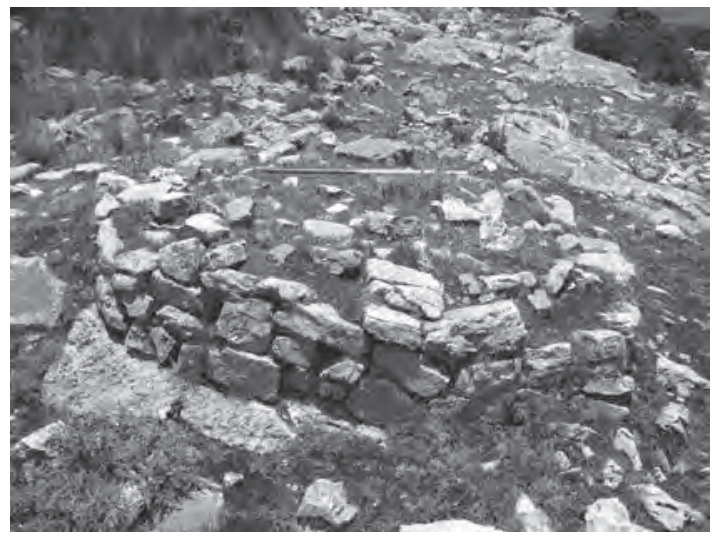

Figura 6. Vista de un edificio funerario con planta circular en Anjushmarca.

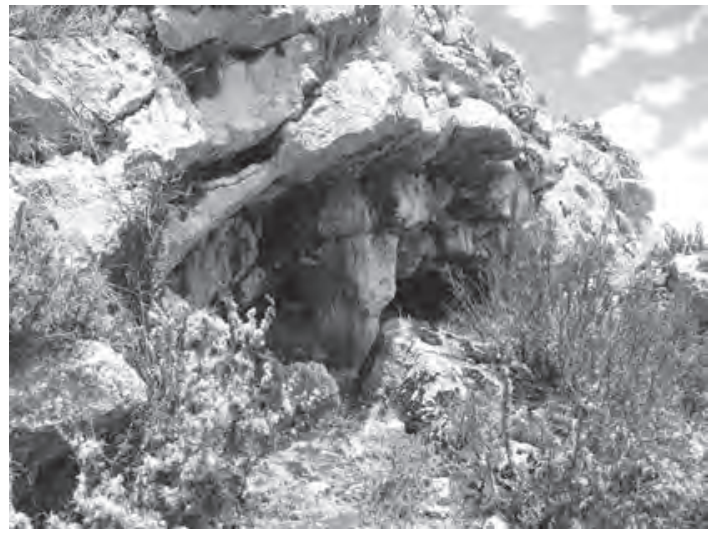

Figura 5. Vista de la caverna funeraria en Anjushmarca.

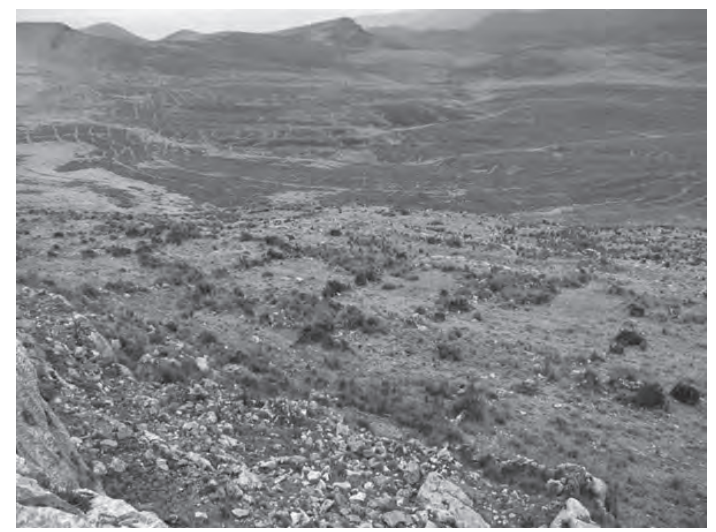

Figura 7. Vista de los corrales de Anjushmarca. 
asentamientos guancas ubicados en la cuenca del río Ricrán, al oeste de Anjushmarca, y con los sitios de Tunanmarca y Umpamalca ubicados en la región de Yanamarca. Por la evidencia arqueológica que hallamos durante nuestra investigación, podemos determinar que Anjushmarca tuvo interacción con los taramas, pues hemos hallado en el sitio fragmentos de cerámica San Blas. Esto nos demuestra que Anjushmarca se relacionó con asentamientos taramas ubicados en el valle de Tarma como Huanri y Capia.

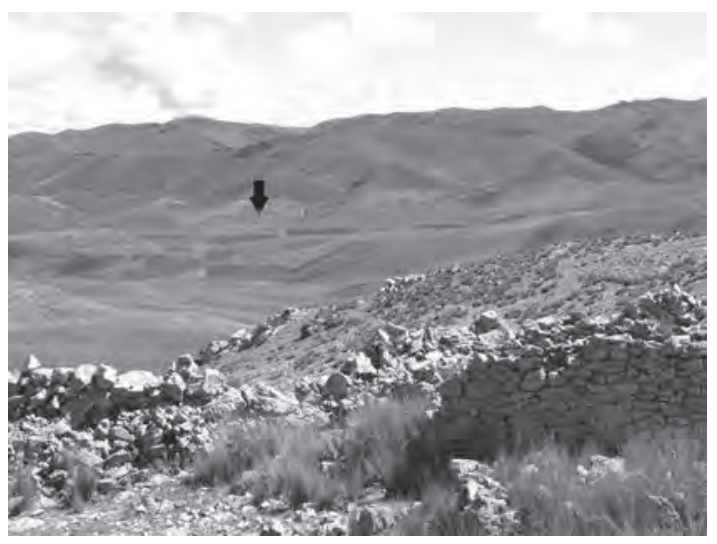

Figura 8. Vista de las tierras de cultivo asociadas a Anjushmarca.

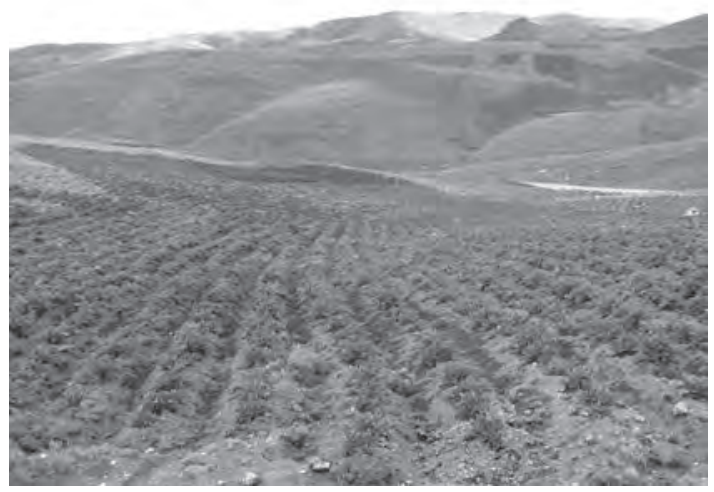

Figura 9. Vista de las tierras de cultivo en Lomo Largo, a solo un kilómetro de Anjushmarca.

\section{соTо сото}

Este asentamiento se encuentra en la cuenca del río Cunas en la cima del cerro Matará, en una altipampa de puna a $4072 \mathrm{msnm}$. El relieve de la zona es totalmente calcáreo, con una vegetación típica de puna. Y hacia las zonas bajas se encuentra rodeado de amplios campos de cultivo, los cuales se encuentran a menos de medio kilómetro de distancia. Este asentamiento está rodeado de recursos suficientes para desarrollar una actividad agropecuaria, pues cuenta con pampas ideales para el pastoreo y tierras de cultivo con abundante recursos hídrico del río Cunas.

Este asentamiento está construido, en su totalidad, con roca calcárea y argamasa arcillosa de origen calcáreo. En los paramentos de los edificios, se puede apreciar que usaron rocas canteadas y semicanteadas, para lograr un acabado armonioso. Además en algunos de los edificios se puede evidenciar el enlucido que hubo, el cual es de arcilla calcárea muy aferrada en el paramento, lo cual ratifica que estos tipos de recintos estuvieron enlucidos.

Los edificios del sitio presentan características típicas de la arquitectura Guanca; para empezar todo el asentamiento se encuentra rodeado de una muralla perimetral, lo cual es recurrente en asentamientos ubicados en las cumbres de los cerros. Los edificios son de planta circular de un diámetro aproximado de 2 y $3 \mathrm{~m}$, con muros de doble cara con un espesor de 0,40 y 0,50 m. La mayoría de los edificios de este sito se encuentran bien conservados, llegando a una altura de $2 \mathrm{~m}$, con accesos de forma semitrapezoidal de $0,80 \mathrm{~m}$ de alto.

También se aprecia el agrupamiento de dos y hasta cuatro edificios de planta circular, asociados a un patio ovalado. Como también un solo edificio circular con su patio. Todo el sector donde se encuentran estos edificios circulares se agrupan hacia la zona noroeste, mientras que las bases de los corrales se ubican al sur dentro de las murallas perimetrales.

Debido a las prospecciones realizadas por esta región, podemos determinar que este asentamiento habría interactuado con dos asentamientos ubicados al sur de este, que también se encuentran dentro de la influencia del río Cunas. Estos sitios arqueológicos se llaman Ichanmarca y Chuctumarca, ambos sitios se encuentran ubicados sobre colinas y tienen relación directa con el valle, lo cual nos 


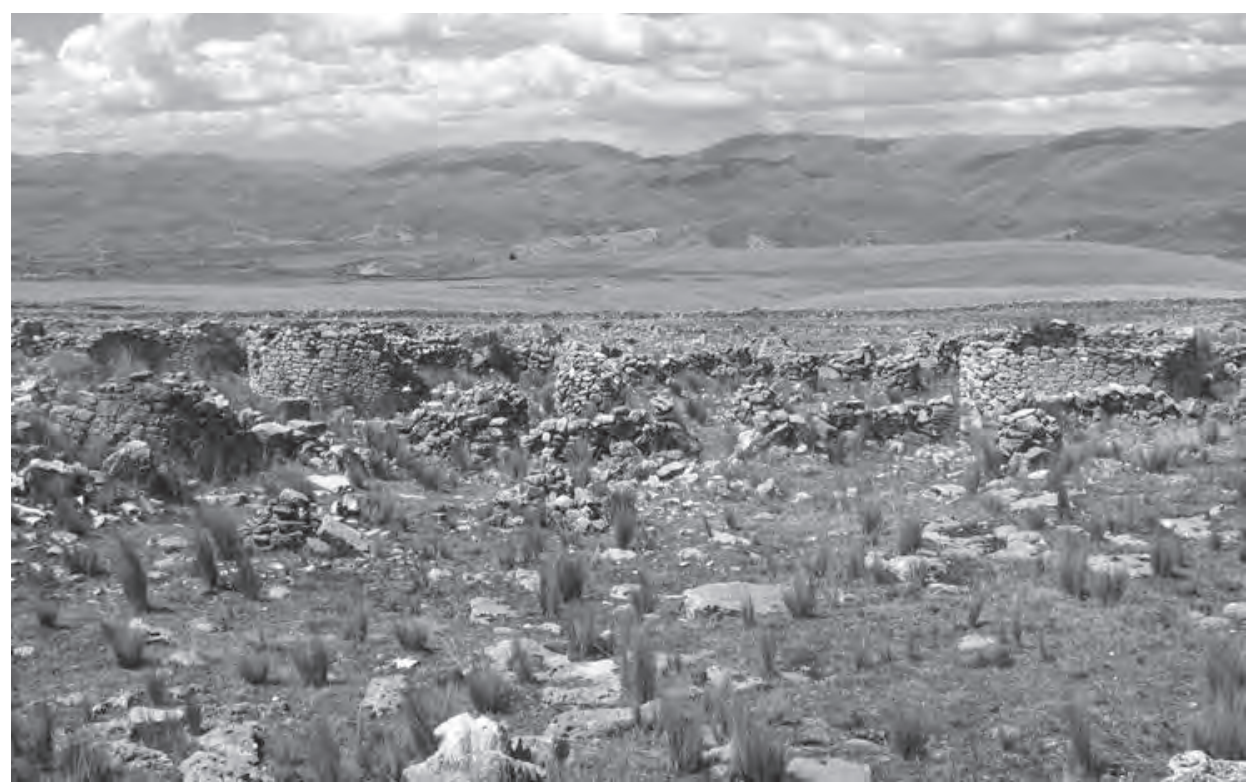

Figura 10. Vista panorámica de Coto-Coto y el paisaje de puna.

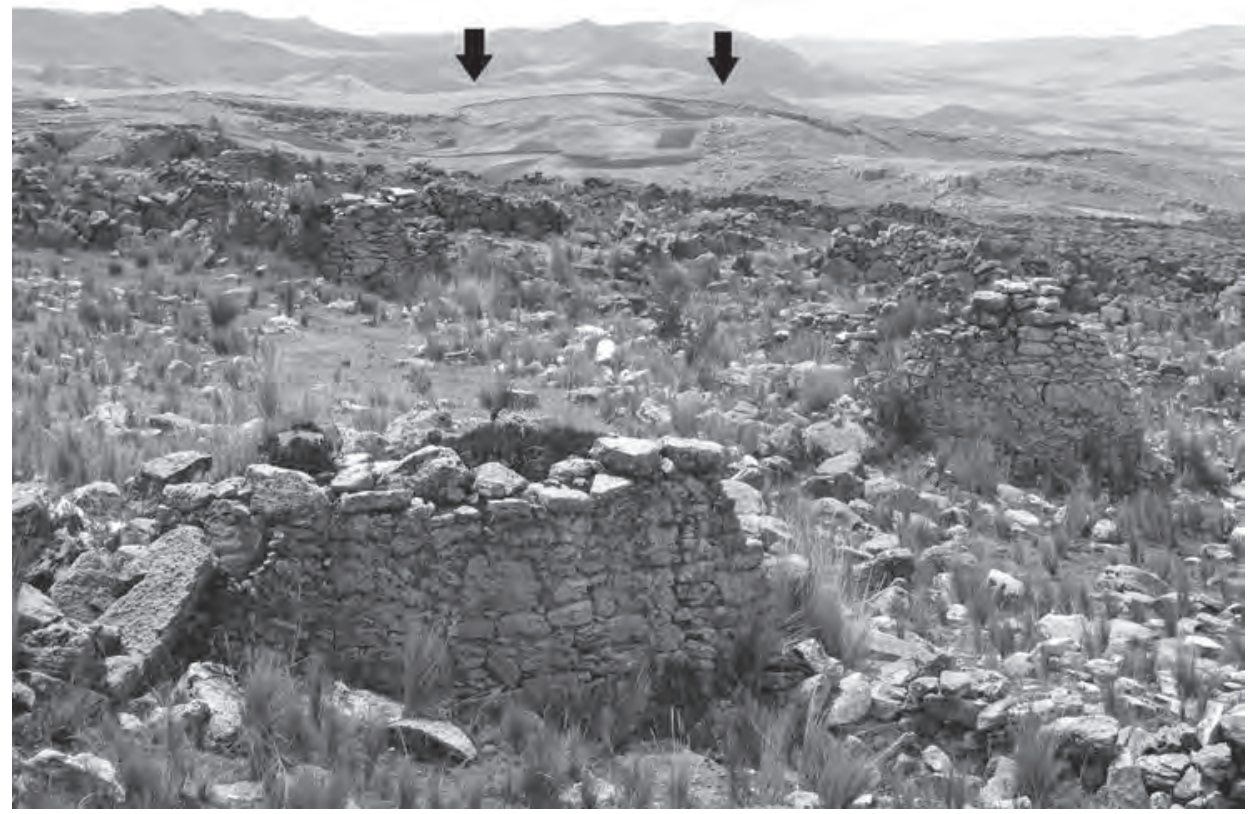

Figura 11. Vista panorámica de Coto-Coto y el paisaje de puna, con evidencia de actividad agrícola.

indica que estarían ligados a la actividad agrícola, y también habrían desarrollado actividades ganaderas, pues en Ichanmarca pudimos detectar la presencia de algunos corrales. Como estos sitios se encuentran en el mismo valle, es muy probable que interactuaran e intercambiaran productos. Además pudieron haberse relacionado con los habitantes guancas de la zona de Yanacancha, ubicados al sur del valle del río Cunas. 


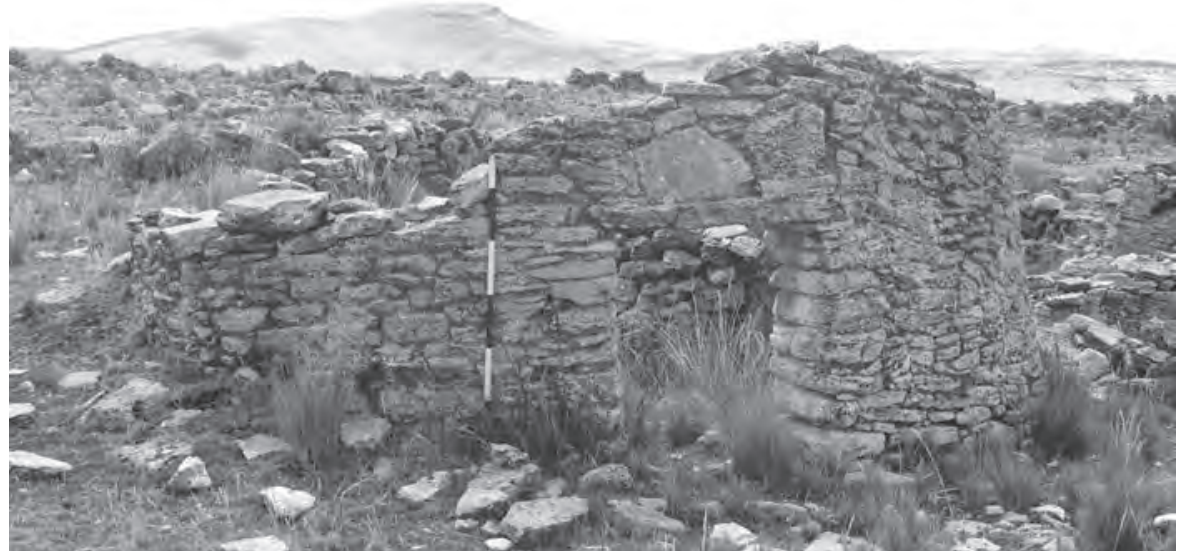

Figura 12. Edificio de planta circular de Coto Coto.

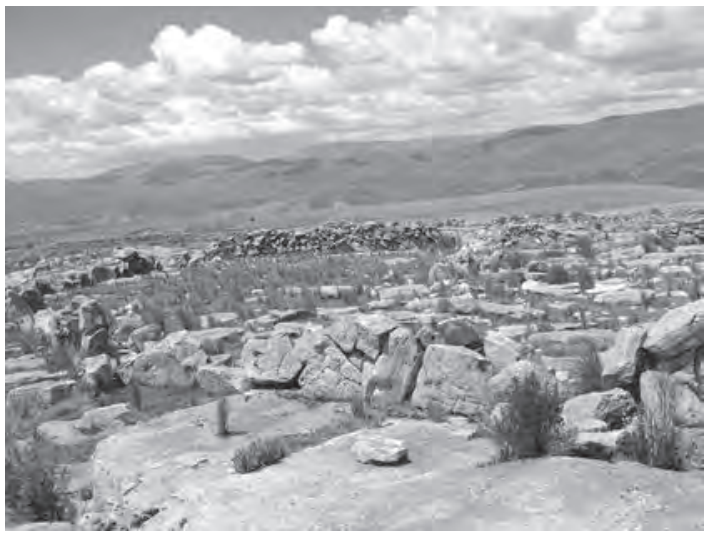

Figura 13. Corrales de Coto-Coto.

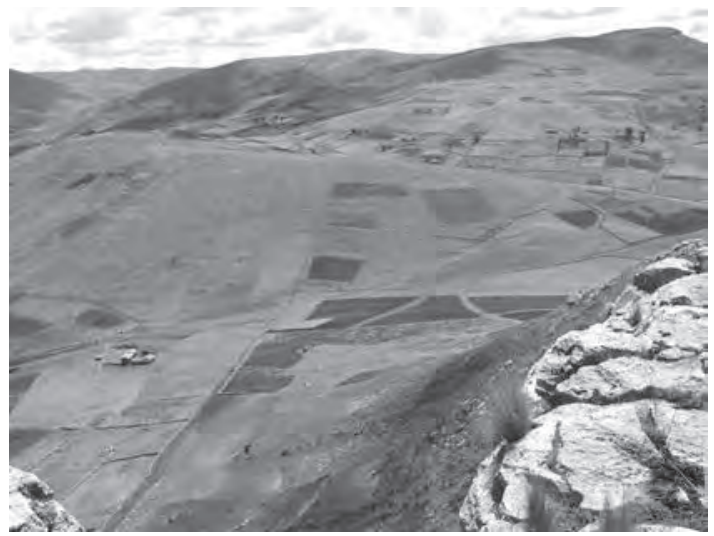

Figura 14. Zona agrícola de Coto-Coto.

\section{COTO COTO (CANCHALLO)}

Coto Coto se encuentra en la localidad de Canchallo, al oeste de Jauja; y presenta una clara filiación cultural guanca, el sitio se ubica en la cima de cerro Coto Coto a $3747 \mathrm{msnm}$. En este asentamiento observamos numerosos sistemas de corrales en la zona suroeste, lo cual evidencia un alto desarrollo ganadero. Si bien Coto Coto se encuentra rodeado de valles, hacia el noroeste de este asentamiento, a unos tres kilómetros, se puede apreciar extensas altipampas de puna, en las cuales se habría podido pastar el ganado de los pobladores de Coto Coto.

Coto Coto también se encuentra directamente asociado a las tierras de cultivo, pues hacia el sureste se encuentra el valle de Pachacayo, irrigada por el río del mismo nombre, que es tributario del río Mantaro. Todo este valle se expande en la zona baja de Coto Coto, a unos cuantos metros de éste; además estas tierras son muy buenas para la agricultura, las cuales habrían sido aprovechadas al máximo por los agricultores de Coto Coto.

Como se puede observar, los pobladores de este asentamiento pudieron realizar una próspera actividad agropecuaria, pues contaron con abundantes tierras fértiles de valle, las cuales son irrigadas por el río Pachacayo; y también contaron con cercanas altipampas de Puna donde pastaron su ganado, además tuvieron amplios y numerosos corrales adecuados para desarrollar una buena ganadería de camélidos. 


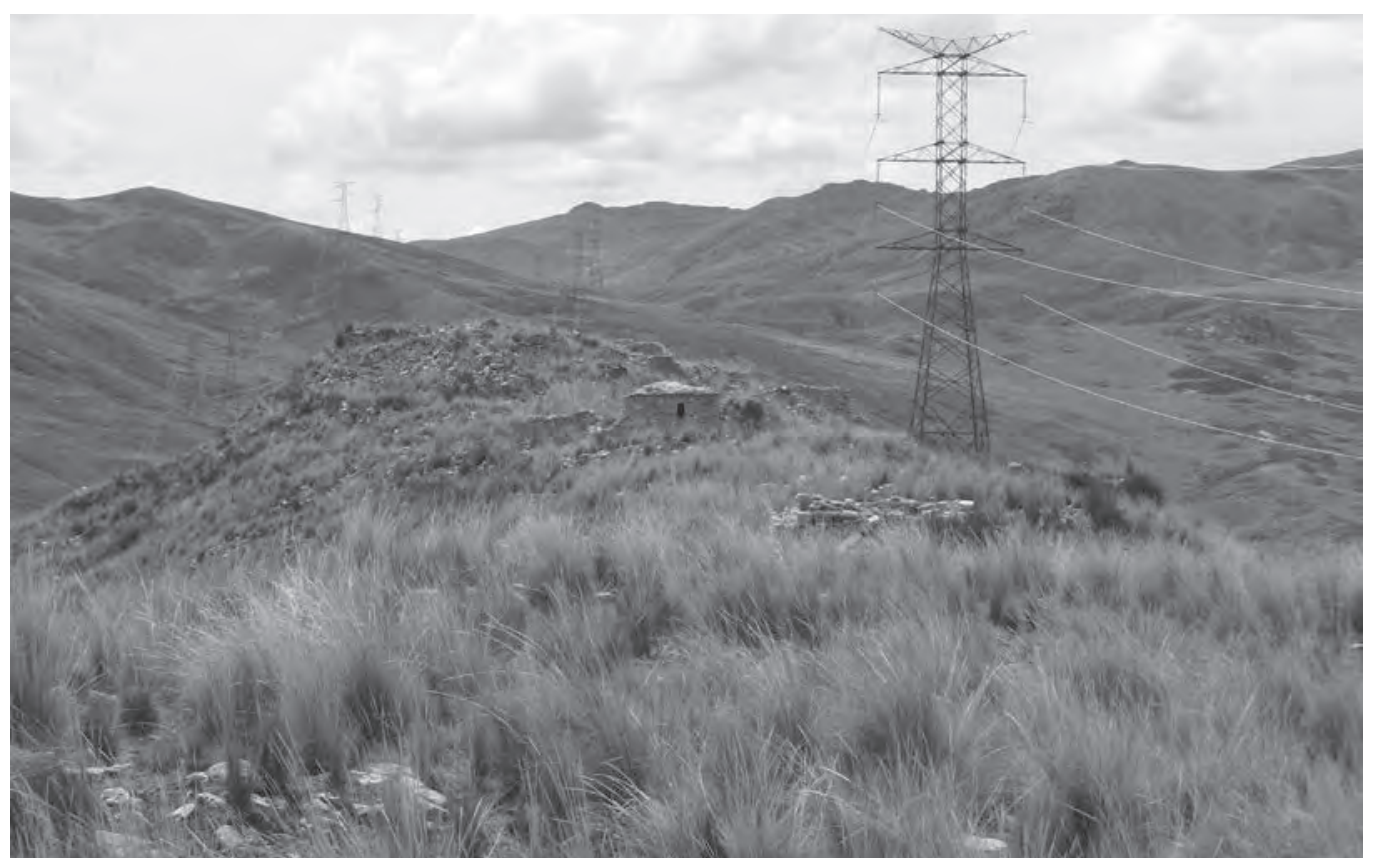

Figura 15. Vista panorámica de Coto-Coto.

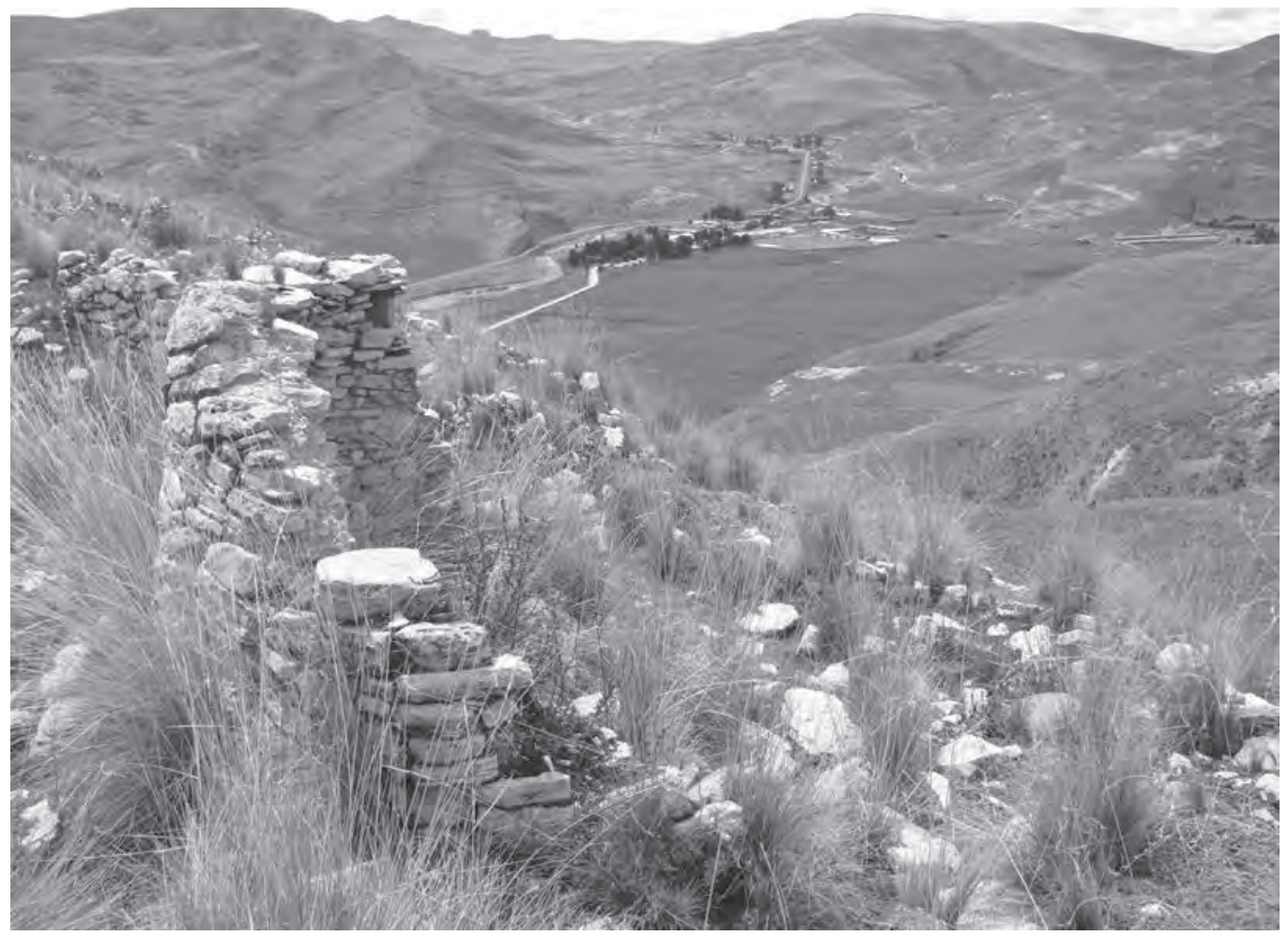

Figura 16. Vista de Coto-Coto y el valle de Pachacayo. 
La arquitectura de Coto Coto muestra edificios construidos con roca calcárea y argamasa del mismo origen. El sitio no presenta muralla perimetral, pero si un conjunto de amplios corrales, los cuales tienen un diámetro de 20 y $30 \mathrm{~m}$. En Coto Coto se evidencian edificios de planta circular con un diámetro de 3 a $4 \mathrm{~m}$, con un acceso de forma semitrapezoidal de 0,80 $\mathrm{m}$ de alto; los muros de estos edificios miden entre 0,40 y 0,50 m de ancho y son de dos caras. También pudimos observar la típica disposición guanca de los edificios circulares asociados a patios ovalados. Como el sitio se encuentra asentado sobre un relieve irregular, es muy común la presencia de terrazas; las cuales ayudan a estabilizar el terreno y a generar relieves aptos para las edificaciones.

En Coto Coto evidenciamos arquitectura funeraria de dos tipos. El primero muestra edificios de planta circular de dos pisos de alto y techo abombado con salientes. En cada uno de los niveles de este edificio se presenta una ventana trapezoidal de 0,50 $\mathrm{m}$ de alto. El techo abombado esta hecho de largas lajas entrecruzada y sostenidas por ménsulas. Este edificio tiene un diámetro de dos metros y una altura de casi dos metros.

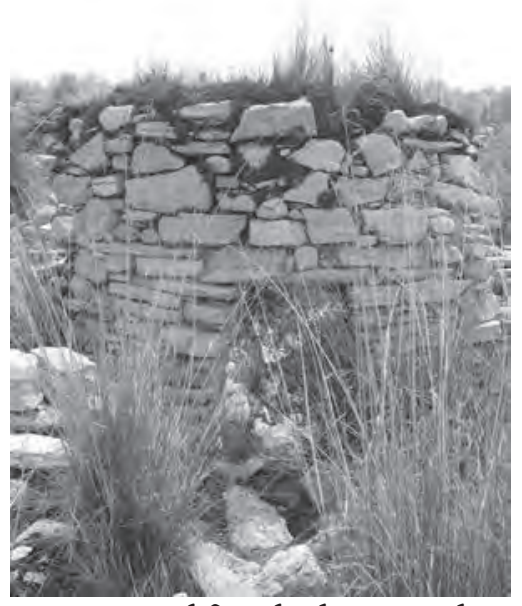

Figura 17. Edificio de planta circular con vano bien conservado de Coto Coto.

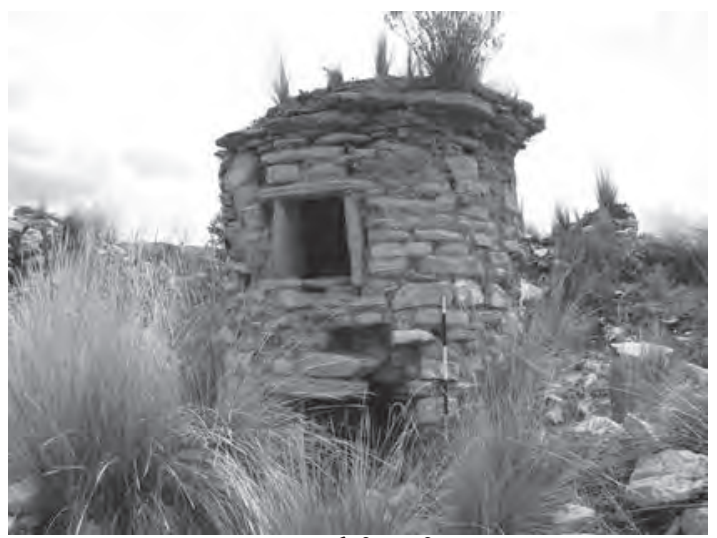

Figura 19. Edificio funerario planta circular de Coto Coto.

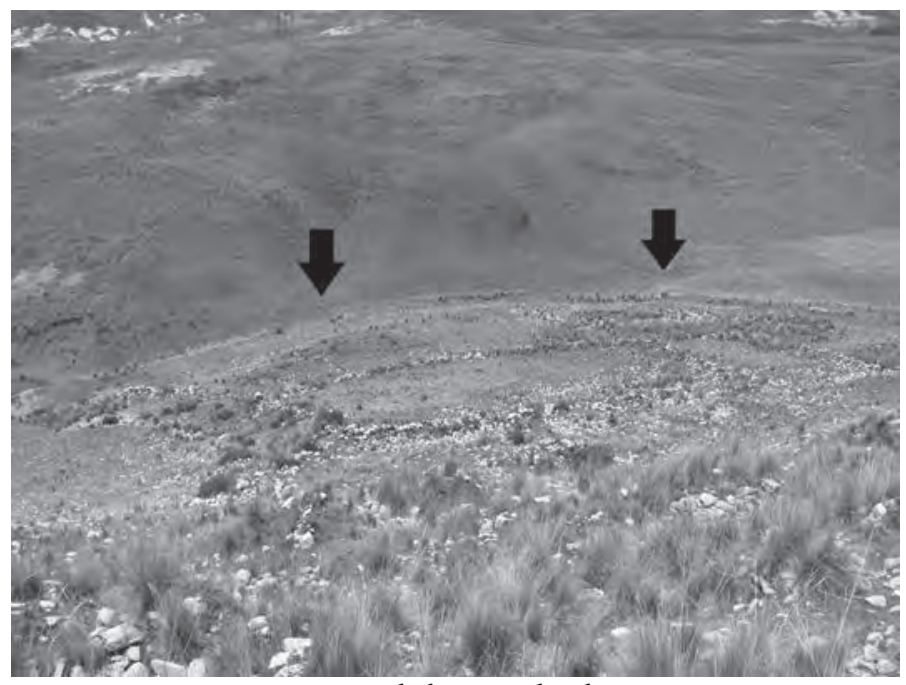

Figura 18. Vista de los corrales de Coto-Coto.

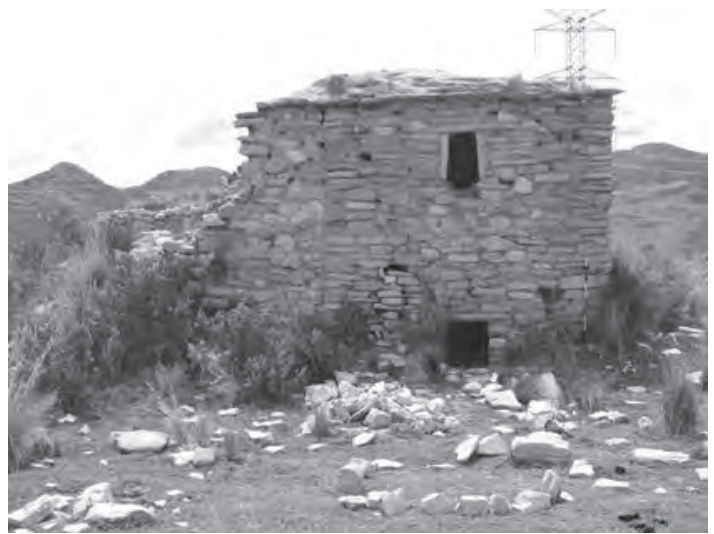

Figura 20. Edificio funerario de planta cuadrangular de Coto Coto. 
El segundo tipo de arquitectura funeraria presenta unas edificaciones de planta semicuadrangular, de dos pisos de alto, con unas dimensiones de $2 \mathrm{~m}$ de ancho y $4 \mathrm{~m}$ de largo, y pueden llegar a medir hasta $3 \mathrm{~m}$ de alto. En cada uno de los pisos de este edificio se muestra una ventana de forma semitrapezoidal de 0,50 $\mathrm{m}$ de alto. El techo de estos edificios es abombado, con salientes en los bordes; en el interior se puede observar que los techos están hechos de largas lajas entre cruzadas sostenidas con ménsulas.

Este asentamiento habría formado lazos de interacción con el sitio arqueológico de Corivinchos ubicado al suroeste de Coto Coto, pues se encuentra dentro de la influencia del valle de Pachacayo, también se relacionaría con el sitio arqueológico ubicado a su paralela, del cual no sabemos el nombre, pero guarda características similares a Coto Coto. Los lazos de interacción con Coto Coto habrían podido llegar hasta la región de Janjaillo, lugar cercano al algo Tragadero, y hasta pudieron llegar a interactuar con el asentamiento de Tunanmarca y Huacjlasmarca.

\section{HUACJLASMARCA}

Huacjlasmarca se ubica dentro de la jurisdicción actual del distrito de Parco, al oeste de Jauja y se encuentra dentro de la influencia del valle del Mantaro. Este asentamiento se encuentra a $4000 \mathrm{msnm}$ sobre una cumbre montañosa. Huacjlasmarca está rodeada por un sistema de tres murallas perimetrales hacia el oeste, mientras que por el norte, sur y está rodeada por un pronunciado acantilado que da cara hacia el río Mantaro. Además desde este asentamiento se puede observar, en toda su plenitud, el valle del Mantaro y el lago Tragadero.

Huacjlasmarca es un asentamiento guanca que también tuvo una ocupación Tawantinsuyo, lo cual se puede evidenciar en las características arquitectónicas del sitio. Las edificaciones en Huacjlasmarca están hechas de roca calcárea canteada y semi canteada, las cuales están unidas por argamasa arcillosa. En este sitio resalta el labrado de la piedra, pues los aparejos de estos edificios son muy armoniosos y elaborados, similares a los que se observan en Tunanmarca.

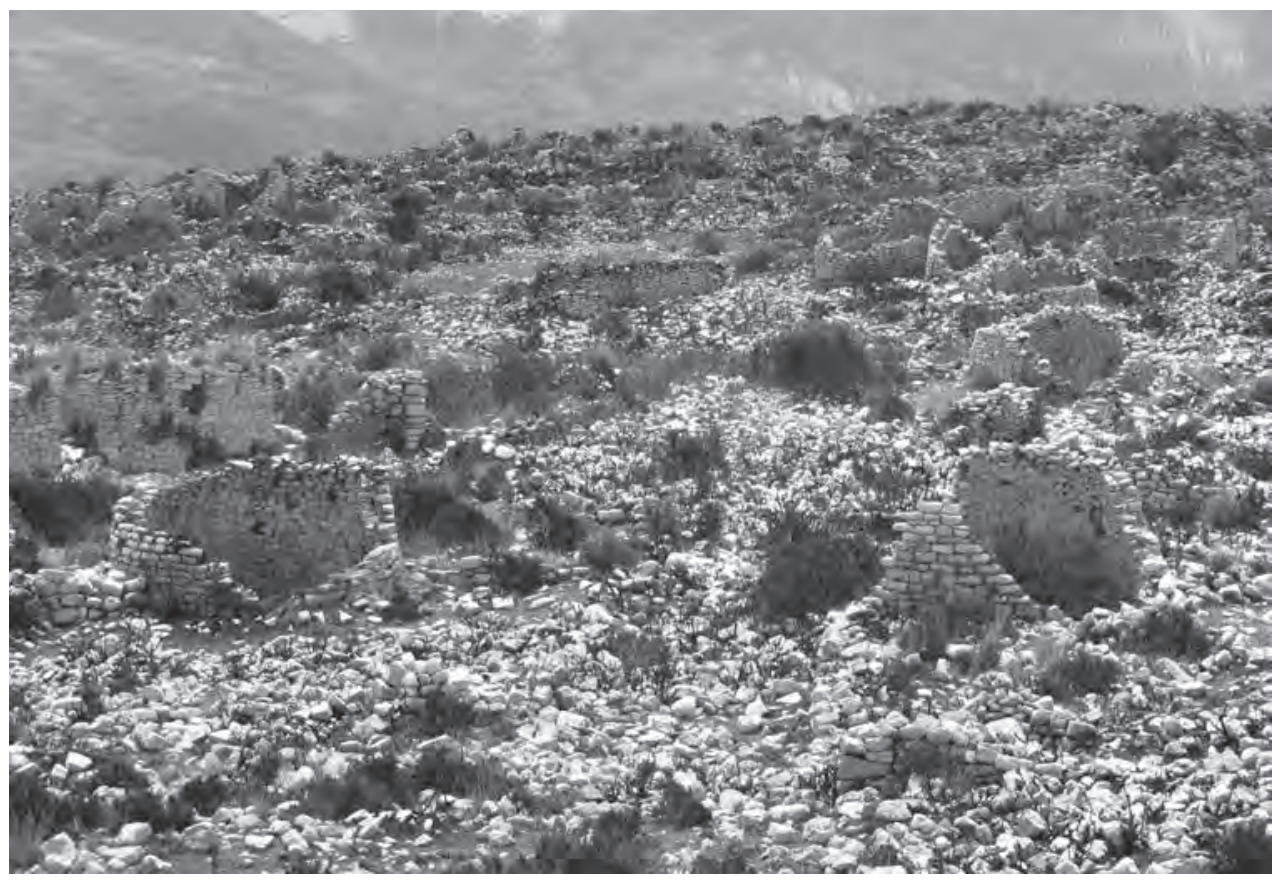

Figura 21. Vista panorámica de Huacjlasmarca. 
Los recintos circulares tienen un diámetro de 4 y $5 \mathrm{~m}$, los muros son de doble cara y poseen 0,40 o 0,50 $\mathrm{m}$ de ancho. Estos edificios de planta circular tienen accesos de forma semitrapezoidal de 0,80 $m$ de alto. La mayoría de estos edificios se encuentran en buen estado de conservación, pues algunos llegan a medir más de dos metros de alto desde la base.

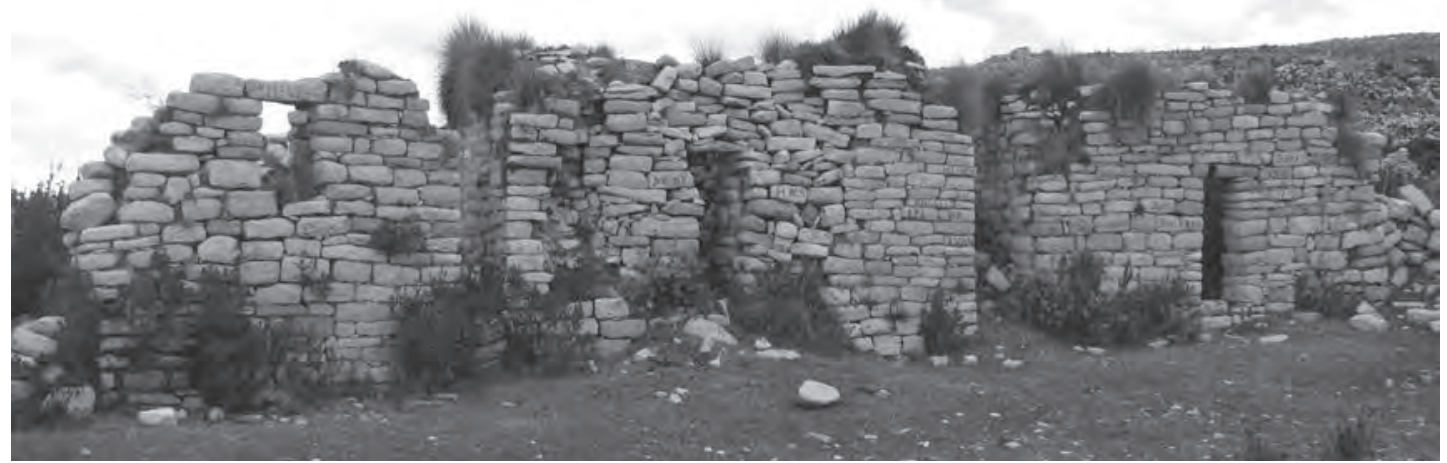

Figura 22. Edificios Tawantinsuyo en Huacjlasmarca.

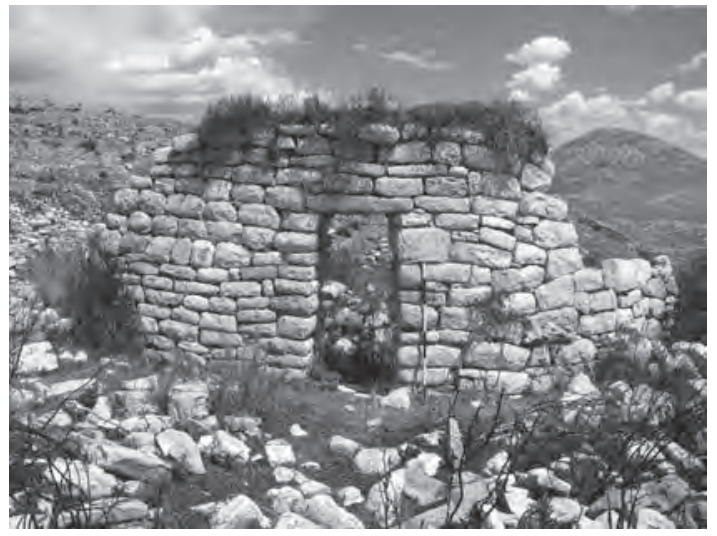

Figura 23. Edificios de planta circular de Huacjlasmarca.

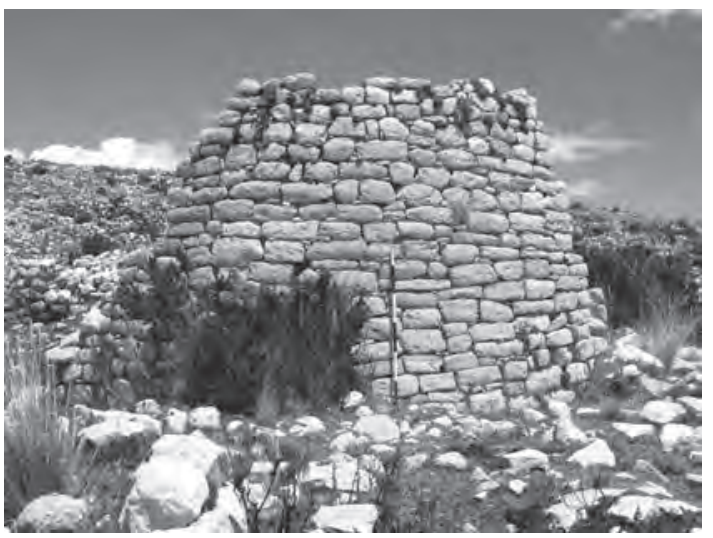

Figura 24. Edificios de planta circular, vemos un paramento con acabado en mosaiqueria de Huacjlasmarca.

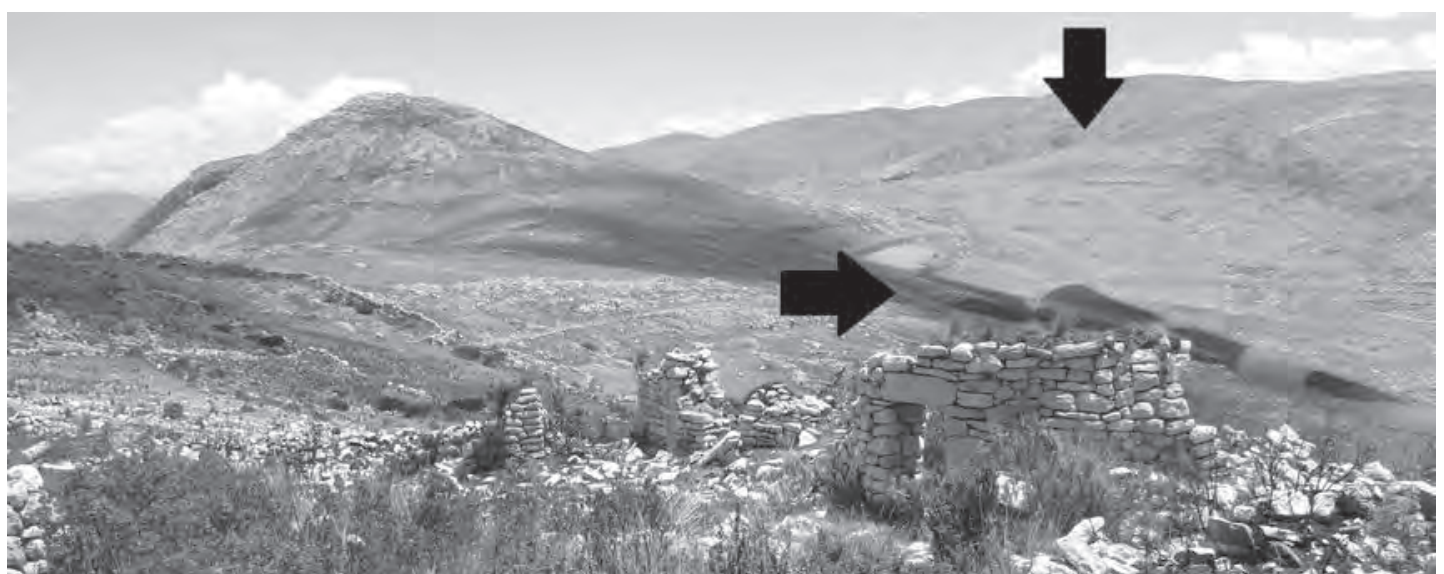

Figura 25. Vista de Huacjlasmarca con los campos de cultivo y las altipampas de puna. 
En Huacjlasmarca se puede evidenciar las agrupaciones de los recintos circulares habitacionales con amplios patios ovalados, lo cual es una disposición típica guanca. Estos agrupamientos de recintos pueden ser de dos o cuatro edificios circulares. Además, en la zona central de Huacjlasmarca se encuentran agrupados los edificios de planta rectangular, con accesos y ventanales de forma trapezoidal; estas serían las manifestaciones arquitectónicas Tawantinsuyo en Huacjlasmarca.

Al noreste de Huacjlasmarca se encuentra un grupo numeroso de corrales, los cuales habrían albergado a todo el ganado criado por los pobladores de este asentamiento. Ellos habrían desarrollado el pastoreo de estos animales en las altipampas de puna que se encuentran a dos kilómetros hacia el oeste de Huacjlasmarca.

El desarrollo agrícola, por parte de los pobladores de Huajclasmarca, se habría producido en las áreas próximas a este sitio, pues hacia el oeste de Huacjlasmarca se expanden amplias tierras de cultivo. Estas zonas agrícolas son usadas hasta la actualidad y también habrían sido provechadas por los habitantes de este asentamiento. Además a unos dos kilómetros hacia el noroeste del sitio, se encuentra una quebrada cultivable, en donde se ubica el poblado actual de Mata Grande, en el cual también se habría desarrollado su agricultura.

Con todo lo expuesto se evidencia que en Huacjlasmarca se desarrolló una plena actividad agropecuaria, pues la actividad ganadera aprovechó las pampas de puna ubicadas al oeste del sitio; mientras que la agricultura se desarrollo en las zonas agrícolas cercanas a Huacjlasmarca. Todos estos recursos naturales esenciales para la actividad agropecuaria, se encuentran a un radio máximo de tres kilómetros de Huacjlasmarca.

La ubicación de Huacjlasmarca, tan cercana al valle de Yanamarca, habría hecho que los pobladores de este asentamiento se relacionaran de forma directa con Tunanmarca, Umpamalca y Hatunmalca. Generándose entre ellos una constante interacción social y económica. Además habrían podido llegar a interactuar con la región de Pachacayo, ya que también se encuentra dentro de la influencia de la cuenca del río Mantaro, siendo este el punto más lejano de sus lazos de interacción.

\section{MARCAHASHA}

Se encuentra ubicada dentro de la provincia de Jauja, en la zona sur de la región de Lomo Largo, a la altura del kilómetro 28 de la carretera Jauja-Tarma. Marcahasha se emplaza en la cima de un cerro escarpado a $4280 \mathrm{msnm}$, sobre una base de roca calcárea muy común en Lomo Largo.

Este asentamiento guanca, presenta edificios de planta circular de 4 y $5 \mathrm{~m}$ de ancho, con una altura de 1,50 m, accesos de 0,70 m de ancho en la base; como este asentamiento se encuentra en muy mal estado de conservación, no se evidencia accesos de forma semitrapezoidal en buen estado de conservación. En Marcahasha también se pueden observar los basamentos de los agrupamientos de recintos circulares con patios ovalados. Este sitio presenta muchas terrazas, pues el relieve donde se asentó este sitio es muy irregular, y estas terrazas ayudan a generar estables terrenos donde se puede construir.

Marcahasha presenta un sistema de numerosos corrales, ubicados en la zona oeste del asentamiento, en la falda del cerro. Este asentamiento debió haber desarrollado una intensa ganadería, pues cuenta con amplias pampas con forraje y bofedales en la zona sur y norte de este sitio, lo cual ayudaría a mantener un alto nivel de producción ganadera.

Los pobladores de Marcahasha también habrían desarrollado actividad agrícola, pues a solo tres kilómetros al sur de este asentamiento, en las cercanías del poblado de Shaihui, se extienden amplias zonas agrícolas, en las cuales se pueden sembrar tubérculos de altura, pues estas tierras se ubican a 4000 msnm. Además, a cuatro kilómetros al sureste de Marcahasha se encuentra la quebrada de Tingopaccha, la cual cuenta con tierras cultivables con abundante recurso hídrico para los riegos de los sembríos. Estas tierras también habrían sido aprovechadas por los pobladores de Marcahasha, para desarrollar su agricultura. 


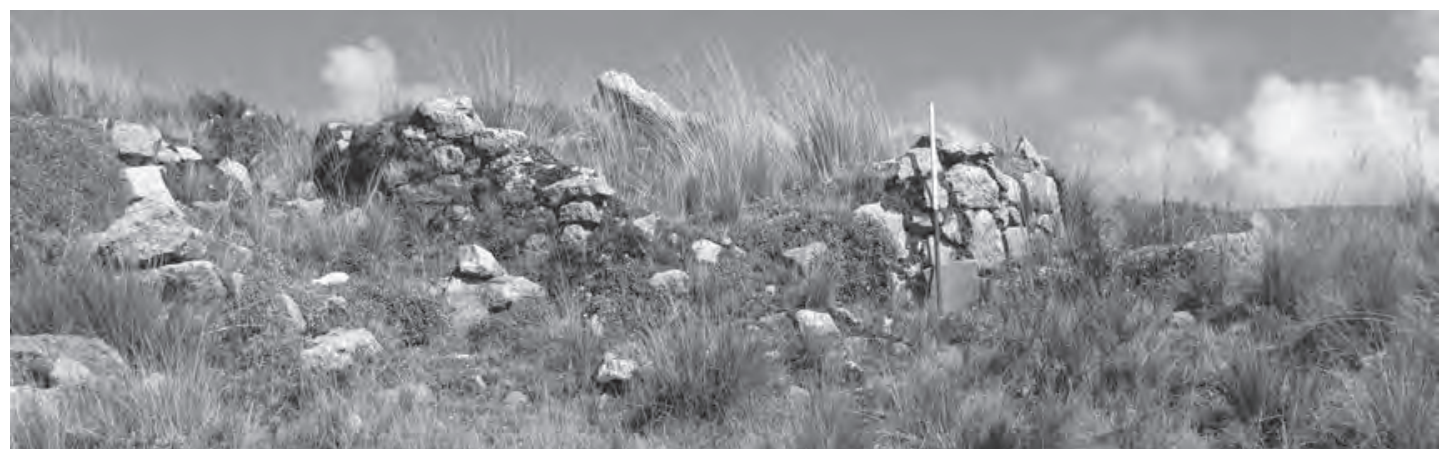

Figura 26. Edificio habitacional de planta circular de Marcahasha.

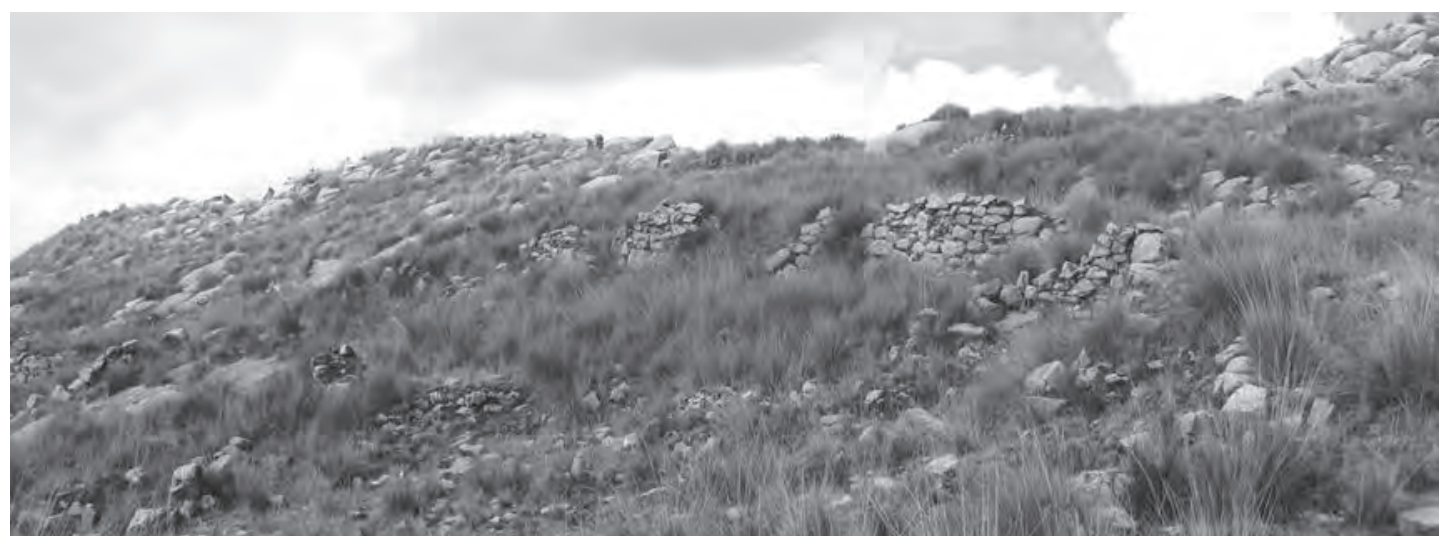

Figura 27. Vista de algunas terrazas de Marcahasha.

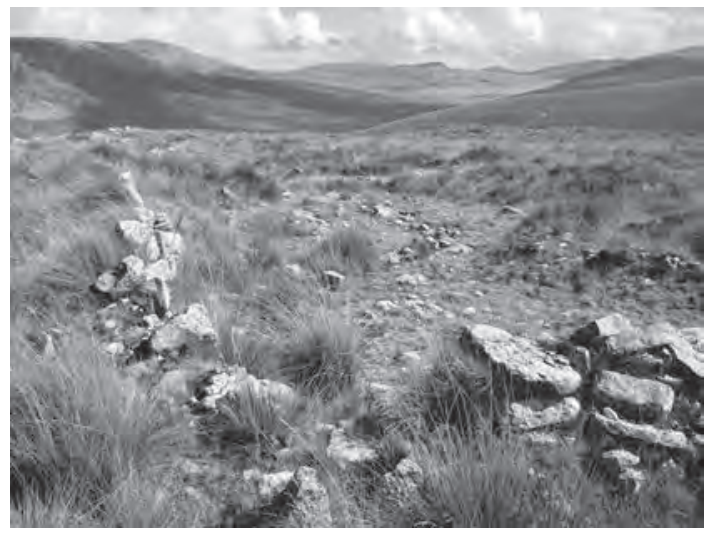

Figura 28. Vista de los basamentos de los corrales de Marcahasha.

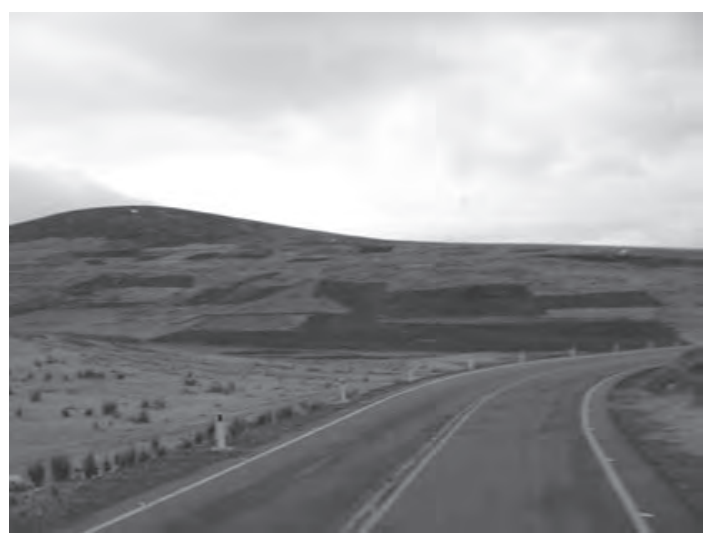

Figura 29. Vista de las tierras de cultivo de Marcahasha.

Como vemos, Marcahasha fue un asentamiento guanca con desarrollo agropecuario. Pues cuenta con las amplias altipampas de Lomo Largo para desarrollar el pastoreo, y con tierras aptas para su agricultura en la zona sur de Lomo Largo.

Este sitio arqueológico habría formado lazos de interacción con Anjushmarca, el cual se ubica a sólo cuatro kilómetros al norte de Marcahasha y está dentro de la región de Lomo Largo. También se habría relacionado con la zona baja del valle de Yanamarca, especialmente con Tunanmarca, Umpa- 
malca y Hatunmalca. Pues entre estos dos tipos de asentamientos, además de formar lazos de relación social, también intercambiaron productos de puna como la maca, la mashua, la oca, la papa de puna y ganaderos como textiles; por productos de valle como el maíz, la quinua, la papa y algunos frutos muy necesarios para complementar la dieta alimenticia de los habitantes de puna. Este sería un claro ejemplo de intercambio de productos entre habitantes de zona de puna con los habitantes de zona de valle. Además habrían podido interactuar con sitios tarama como Capia y Huanri, ubicados muy cerca del extremo norte de Lomo Largo. Así mismo, también se relacionarían con los guancas asentados en la cuenca del río Ricrán.

\section{Sitios ARQUEOLÓGICOS TARAMA}

\section{ANASHPATA}

Anashpata se encuentra ubicado muy cerca del poblado de Sacramachay, en el distrito de Palcamayo, Tarma. Este asentamiento se encuentra al pie del cerro Shayoc-Shayoc a $4306 \mathrm{msnm}$. Anashpata presenta doble muralla perimetral solo en la zona oeste, pues el resto del asentamiento se encuentra rodeado por los afloramientos rocosos de la montaña. Además existen muchas terrazas, las cuales ayudan a nivelar el relieve irregular donde está asentado el sitio. Sobre estas terrazas se edificaron edificios de planta circular, con muros de doble cara y con unos accesos de forma semitrapezoidal de $0,80 \mathrm{~m}$ de alto; además estos recintos circulares tienen un diámetro de $405 \mathrm{~m}$ y sus muros un ancho de 0,40 y 0,50 m. En algunos de estos edificios de planta circular, existe la evidencia de pequeños nichos trapezoidales.

En Anashpata podemos evidenciar, recintos circulares asociados a unos patios pequeños de forma rectangular o cuadrada. Esta disposición de un solo recinto circular con su patio, es una típica disposición arquitectónica de los taramas. Debemos señalar, que todas estas construcciones fueron hechas con roca calcárea y mortero arcilloso de origen calcareo.

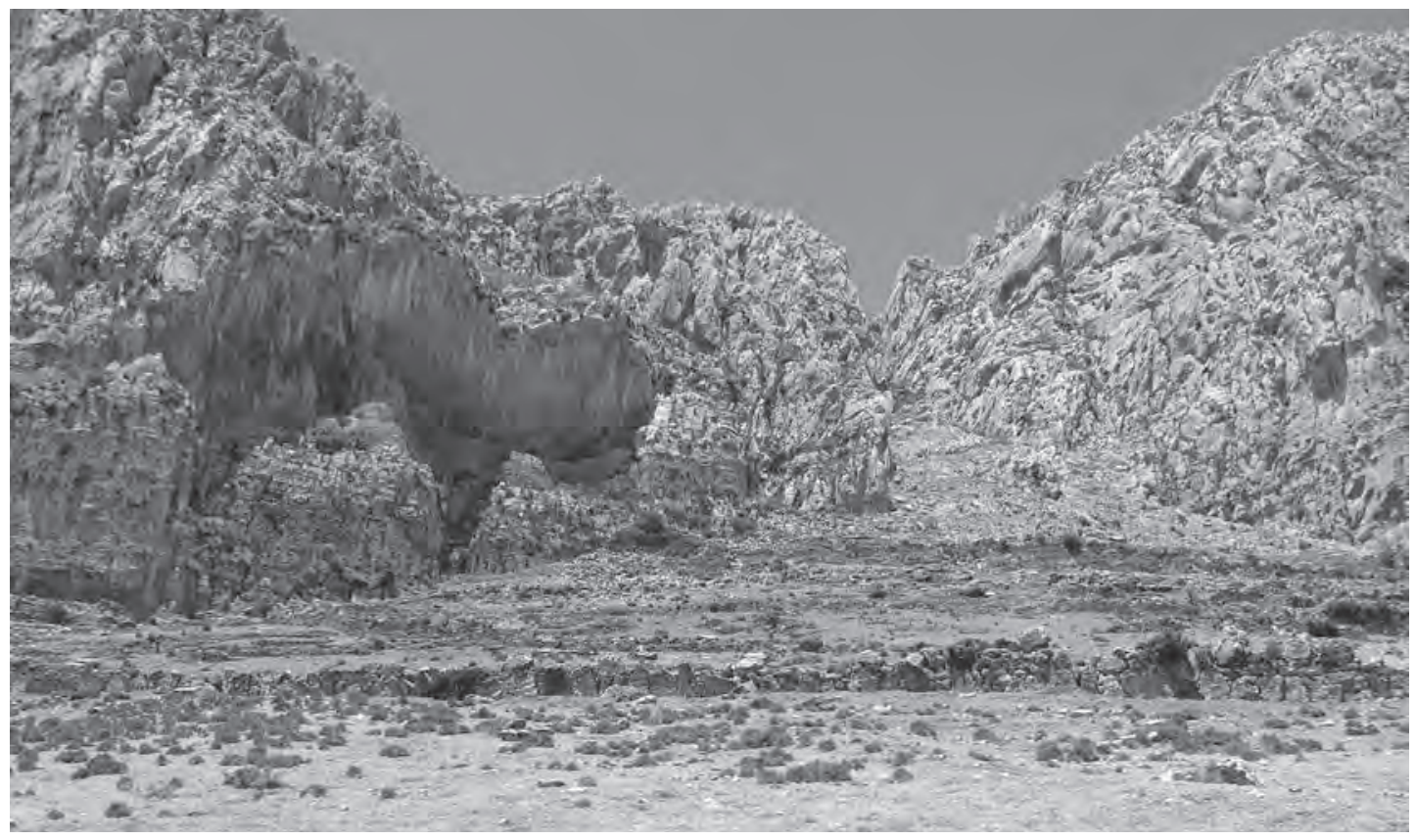

Figura 30. Vista panorámica de Anashpata. 
También se puede observar arquitectura funeraria, la cual se encuentra adosada a las paredes rocosas del cerro, se observa que se cantearon estas paredes rocosas para luego cerrarlas con pequeños muros; dentro de estas cavidades se encontró material óseo humano.

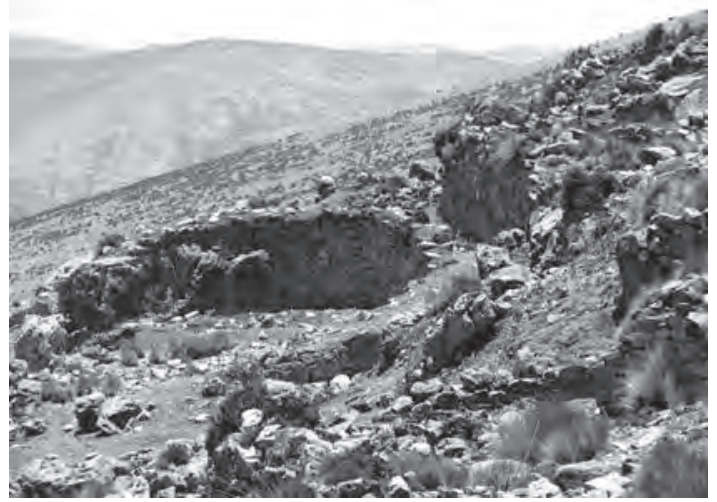

Figura 31. Edificios de planta circular asociado a terrazas de Anashpata.

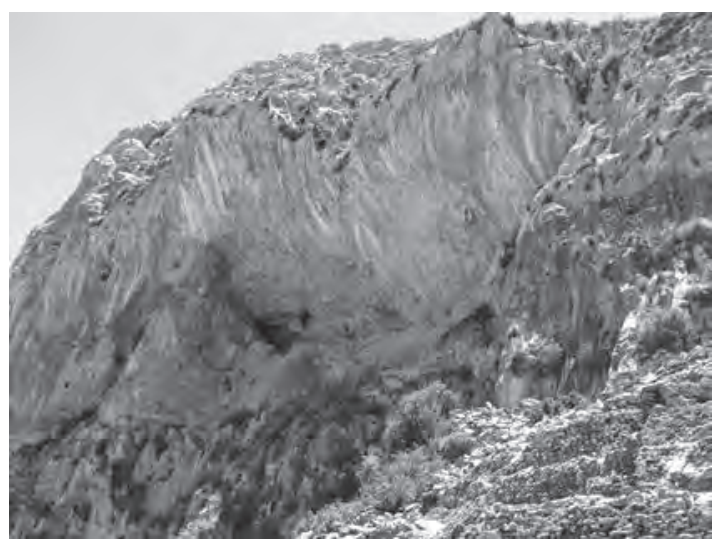

Figura 33. Caverna funeraria ubicada en la cima del sitio de Anashpata.
Figura 35.Vista del área de cultivo de Anashpata.

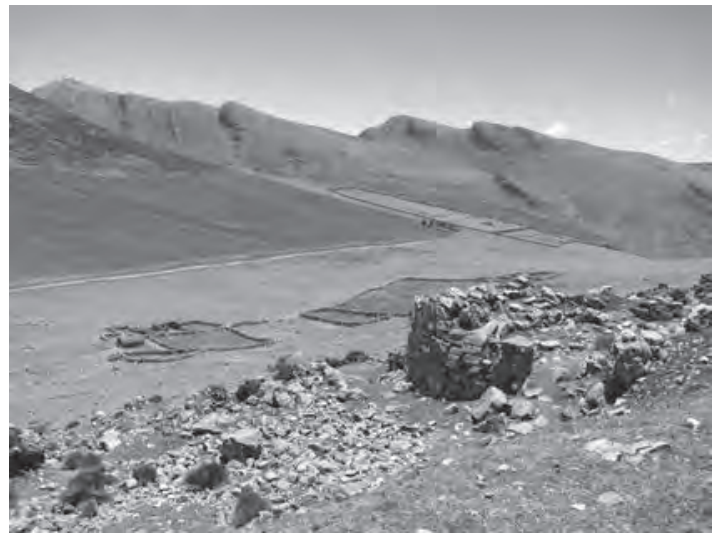

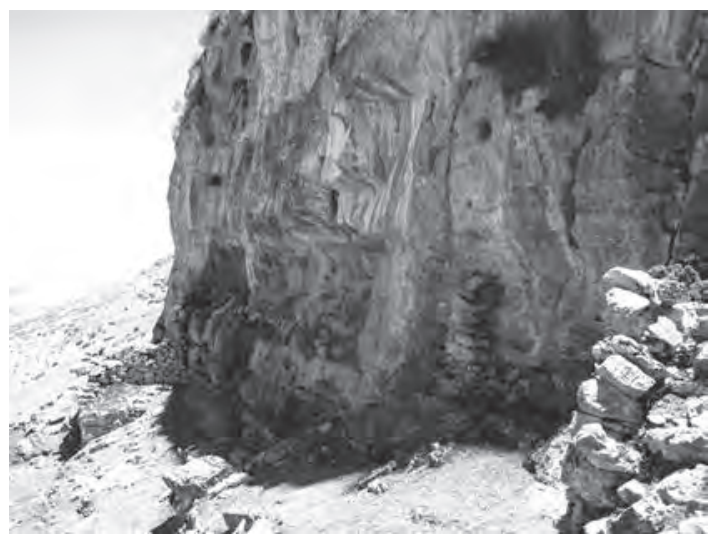

Figura 32. Basamentos de arquitectura funeraria adosada a las paredes rocosas en Anashpata.

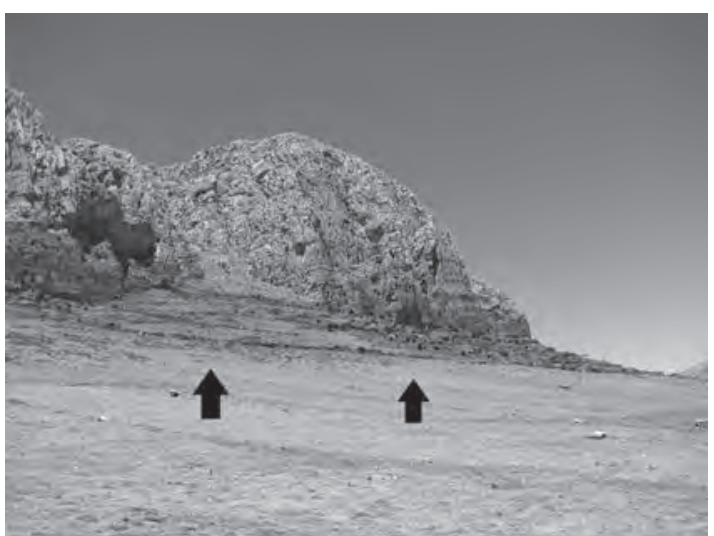

Figura 34. Vista de Anashpata, en donde se muestra algunas de las delimitaciones de los corrales.

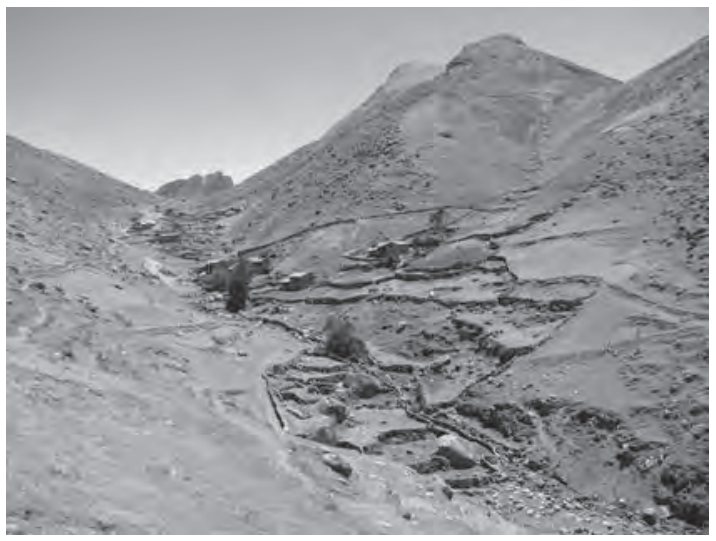

Figura 36. Vista de la quebrada Hualli Uran. 
En la cima de este asentamiento se muestra una enorme caverna rocosa de más de $30 \mathrm{~m}$ de largo y $40 \mathrm{~m}$ de alto, esta gigantesca caverna de difícil acceso, habría cobijado a muchas edificaciones funerarias, pues nos cuentan los pobladores de la zona que dentro de esta caverna, aun se pueden encontrar cimientos de edificios funerarios y material óseo humano.

En este asentamiento también se habría desarrollado una prospera actividad agropecuaria, pues hacia el extremo oeste de Anashpata, dentro de los muros perimetrales, podemos evidenciar rastros de algunos corrales de forma ovalada, las cuales han sufrido mucho deterioro, pues sólo pudimos identificar rastros de éstos; también encontramos material óseo de camélidos dentro de estos corrales. Lo cual nos demuestra que los pobladores de Anashpata desarrollaron actividad ganadera.

También habrían desarrollado la agricultura, pues este asentamiento se encuentra rodeado de tierras cultivables; la más cercana se encuentra al oeste del sitio a solo $50 \mathrm{~m}$, estas tierras cultivables se encuentran en una extensa ladera de cerro. Además al noreste de Anashpata a menos de un kilómetro de distancia, se encuentra la quebrada de Hualli Uran, la cual posee tierras cultivables y recursos hídricos, la cual también habría sido explotada por los pobladores de Anashpata, pues hasta la actualidad estas tierras son sembradas.

Como Anashpata se ubica en la zona de valle del río Palcamayo, es evidente que interactuó con los asentamientos tarama de este valle, como con Aujsaypan, Huagapo, Yaumanpata y Chaquimarca. Chaquimarca vendría a ser el asentamiento más alejado de Anashpata, pero por la importancia de este sitio, creemos que la interacción extrasitio de Anashpata llegó hasta ahí. Debemos resaltar que el sitio de Chaquimarca es uno de los asentamientos Tarama más impresionantes, el cual también se asocia a terrazas cultivables y a zonas de pastoreo en las zonas altas de la quebrada de Cocón.

\section{AUJSAYPAN}

Este asentamiento Tarama se ubica al suroeste del caserío de Ricrican, en el distrito de Palcamayo en Tarma. Aujsaypan se encuentra a $4340 \mathrm{msnm}$ sobre la cumbre de un cerro, el cual tiene una caprichosa forma cónica; debido a esto el sitio presenta un numeroso sistema de terrazas continuas para poder nivelar y habilitar el relieve calcáreo del cerro, el cual permite la estable construcción de los edificios. Además todo el sitio se encuentra rodeado por una muralla perimetral, que en el lado sur puede llegar a medir hasta $2 \mathrm{~m}$ de alto.

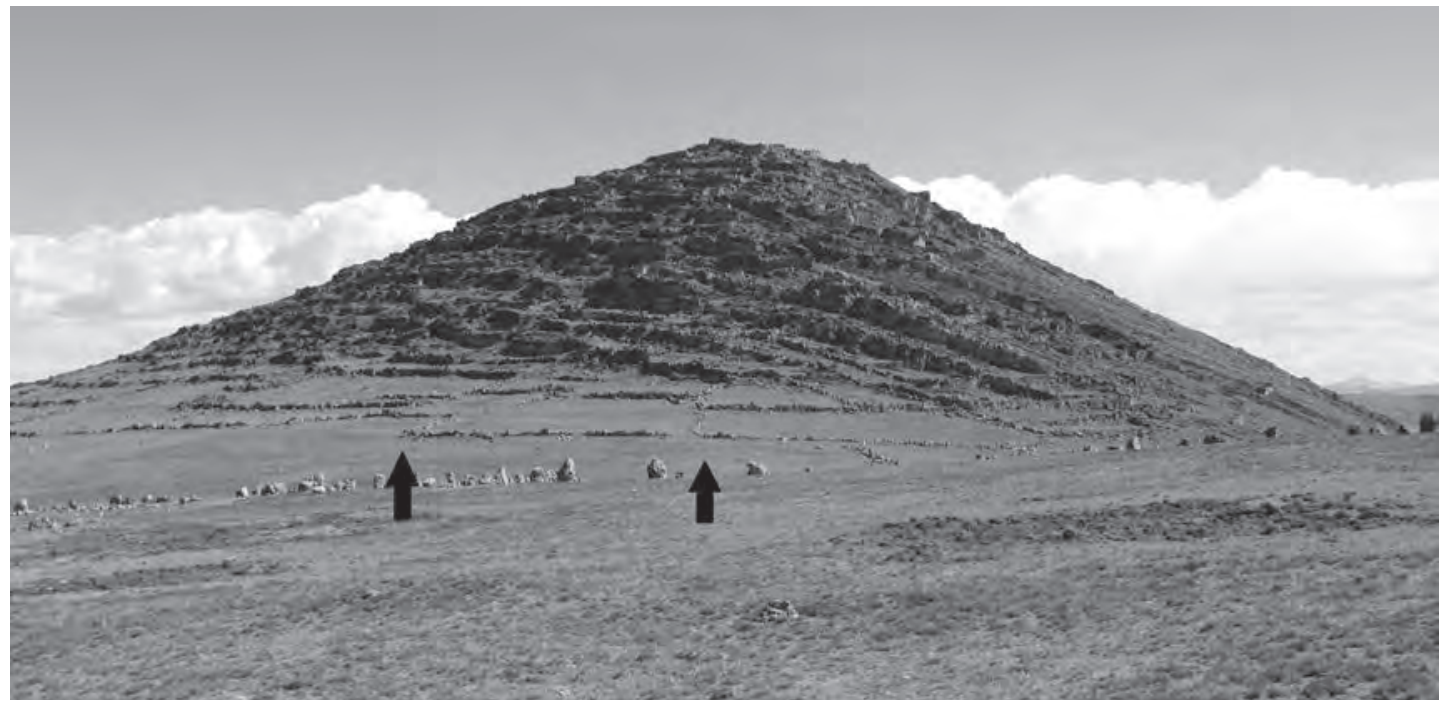

Figura 37. Vista panorámica de Aujsaypan. En la parte baja se puede observar algunos corrales. 
Aujsaypan presenta edificios de planta circular con muros de doble cara y con un diámetro de 2 y $3 \mathrm{~m}$, estos edificios tiene accesos de forma semitrapezoidal de $0,80 \mathrm{~m}$ de alto aproximadamente. Tanto los edificios y las terrazas fueron hechas de roca calcárea y argamasa arcillosa.

En este asentamiento evidenciamos la típica disposición Tarama de un recinto circular asociado a un patio rectangular. También notamos que en la cima de Aujsaypan se encuentran las bases de unos edificios de planta circular de $1 \mathrm{~m}$ de diámetro, el cual podría ser de carácter funerario. También existe otro tipo de edificio funerario, el cual no pasa de 0,90 $\mathrm{m}$ de alto, son edificios de planta rectangular con techo plano y acceso semitrapezoidal de $0,50 \mathrm{~m}$ de alto. Los cuales se ubican cerca de los recintos circulares o dentro de los patios rectangulares de los recintos, dejándolos en una disposición de cara a cara entre el recinto habitacional y la cámara funeraria.

En este asentamiento también se habría desarrollado actividad agropecuaria, pues hacia el noreste se encuentran un conjunto de amplios corrales, con 20 y $30 \mathrm{~m}$ de diámetro, los cuales se encuentran fuera del muro perimetral del asentamiento. El pastoreo del ganado se habría dado por toda la extensa pampa ubicada al norte de Aujsaypan, en donde se ubica actualmente el caserío de Ricrican. Además los pastores de este asentamiento también podrían haber pastado a su ganado, por la zona de puna de Cocón ubicadas al sureste de Aujsaypan.

La actividad agrícola se habría producido en la pendiente montañosa, que se encuentra al pie del cerro donde se asienta Aujsaypan. El área agrícola que habrían aprovechado los pobladores

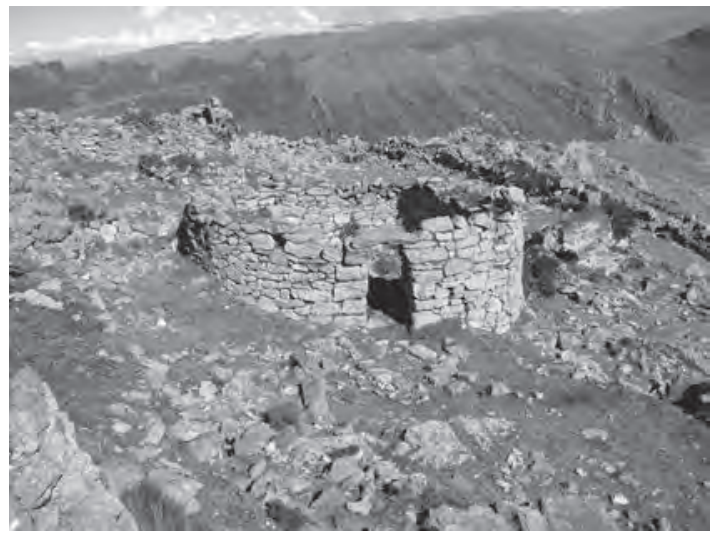

Figura 38. Edificio de planta circular asociado a un patio en Aujsaypan.

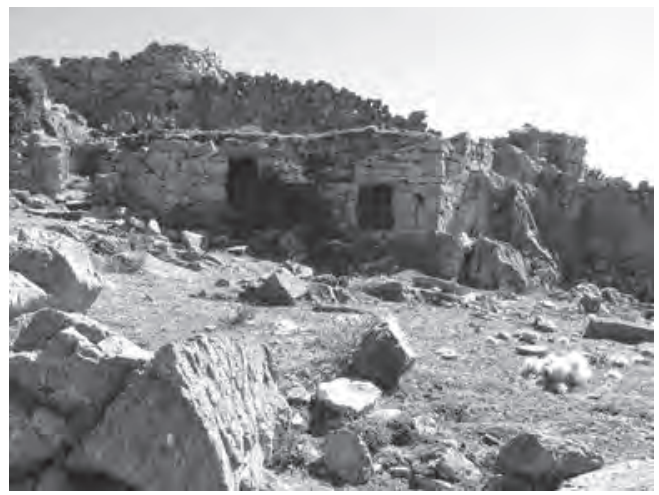

Figura 40. Edifico funerario doble de planta circular en Aujsaypan.

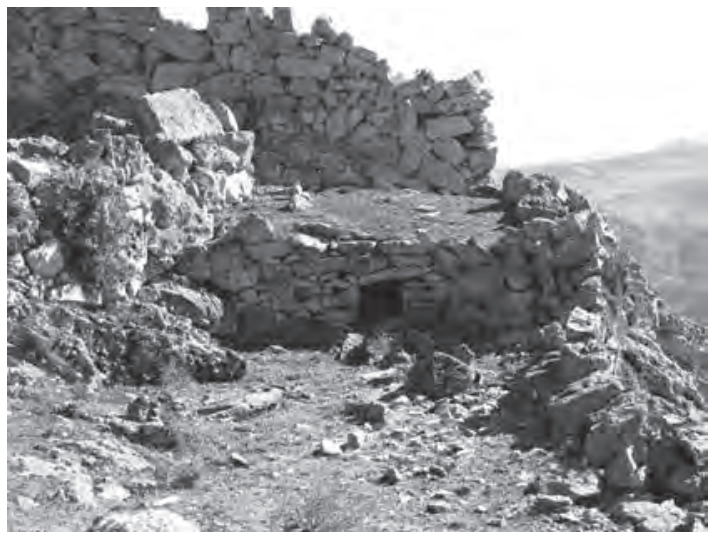

Figura 39. Edificio funerario ubicado en el patio de un recinto circular en Aujsaypan.

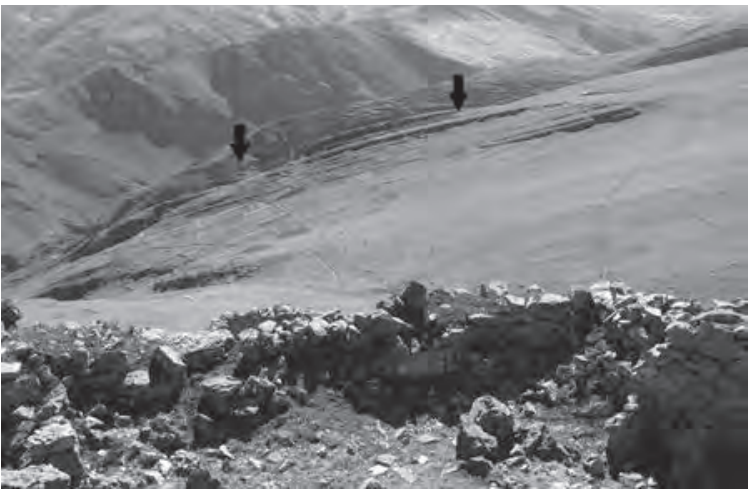

Figura 41. Vista panorámica de las áreas de cultivo de Aujsaypan. 
de Aujsaypan se extiende por toda la ladera montañosa que baja hasta el río Palcamayo, la cual comprende cuatro kilómetros de pendiente cultivable. En la actualidad estas tierras aun siguen siendo aprovechadas y todavía se evidencian rastros de terrazas cultivables.

Aujsaypan habría desarrollado lazos de interacción con los asentamientos ubicados en el valle de Palcamayo, como con Anashpata, Huagapo, Yaumanpata y Chaquimarca. Además Aujsaypan habría interactuado de forma directa con los asentamientos ubicados en la quebrada de Cocón, porque desde la zona de Ricrican se abre un paso natural hacia dicha quebrada, llegando a interactuar con Chaquimarca y con Morallapunta, éste último ubicado en la zona media de la quebrada Cocón.

\section{CHAQUIMARCA}

Chaquimarca se encuentra en el distrito de Palcamayo, este asentamiento se ubica exactamente en la zona alta de la quebrada Cocón a un par de kilómetros al sur de la laguna del mismo nombre. Chaquimarca se ubica sobre una lomada a $3800 \mathrm{msnm}$ y es uno de los más impactantes sitios arqueológicos que hemos visitado, su disposición arquitectónica, su ubicación geográfica y su buen estado de conservación lo hace muy interesante para desarrollar una investigación exhaustiva en el sitio.

Chaquimarca presenta murallas perimetrales que pueden llegar a medir $3 \mathrm{~m}$ de alto. En la zona norte del sitio se encuentra un sistema de doble muralla, estas murallas se encuentran adosadas a edificios de planta cuadrangular, las cuales hacen ver mucho más imponente a las murallas. Estos edificios de planta cuadrada tiene una función funeraria, pues en la parte superior presentan una ventana de forma semitrapezoidal, la cual es una típica disposición de los edificios funerarios de esta región,

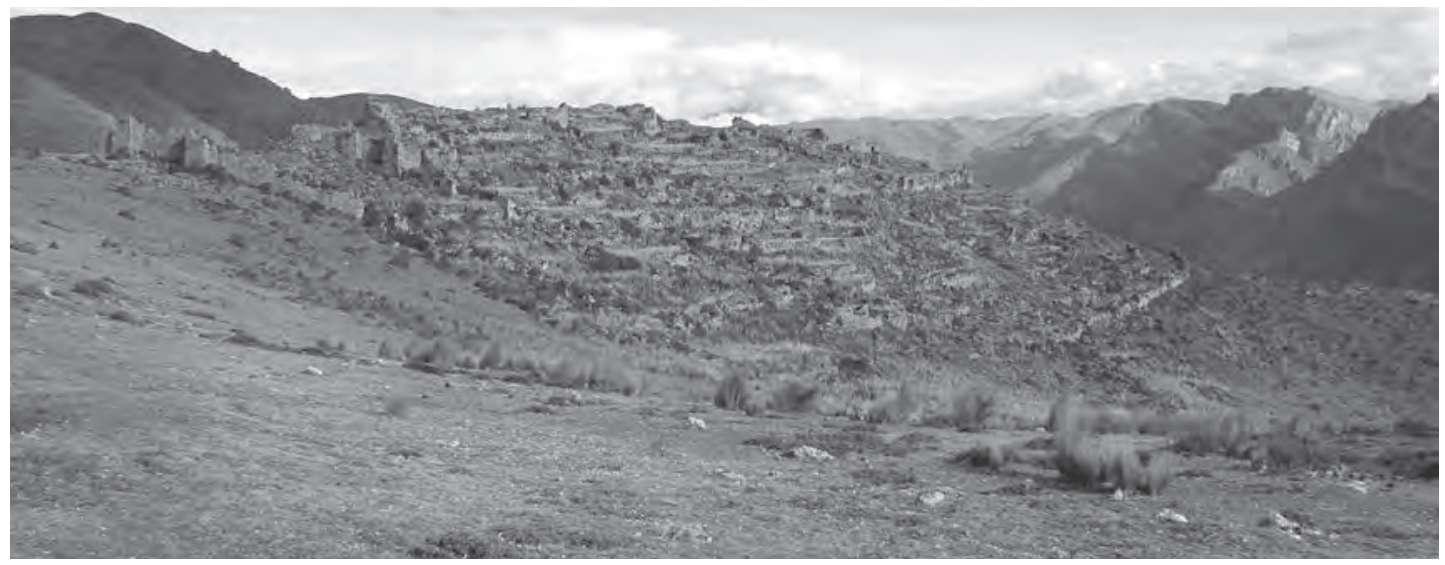

Figura 42. Vista panorámica de Chaquimarca.

además en su interior se puede evidenciar material óseo de humano. En total hemos podido registrar 4 de estos edificios funerarios adosados a las murallas perimetrales, y todas muestran sus ventanas semi-trapezoidal hacia el interior del sitio. Además toda esta zona de Chaquimarca se encuentra en buen estado de conservación.

Como el sitio está asentado sobre una colina, en éste se observa todo un sistema ordenado de terrazas, que ayudan a generar relieves aptos para las construcciones. Sobre estas terrazas se ubican los edificios de planta circular con muros de doble cara y con un diámetro de 2 y $3 \mathrm{~m}$, en algunos de estos edificios poseen nichos de forma semitrapezoidales en su interior; estos edificios tiene accesos de forma semitrapezoidal de $0,80 \mathrm{~m}$ de alto aproximadamente y la gran mayoría se asocian a los patios de formas rectangulares. En Chaquimarca observamos que la disposición arquitectónica de los recintos presenta uno o dos recintos circulares asociados a un patio de forma rectangular, siendo esta una disposición arquitectónica característica en los asentamientos tarama. 


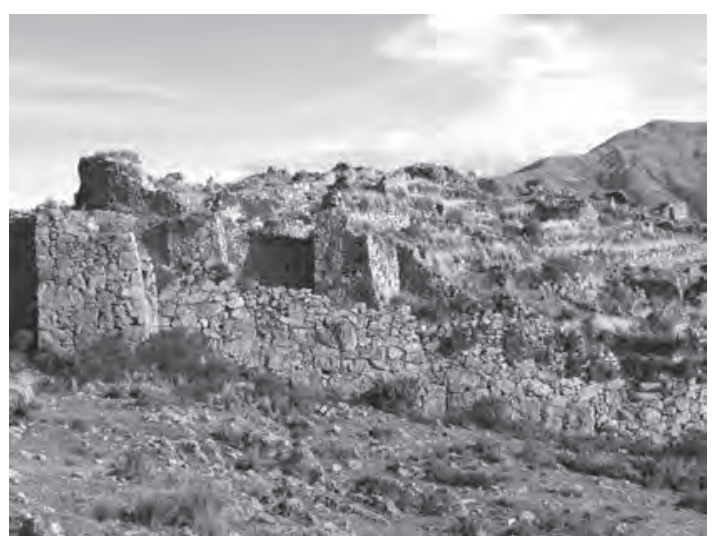

Figura 43. Vista de la doble muralla perimetral de Chaquimarca.

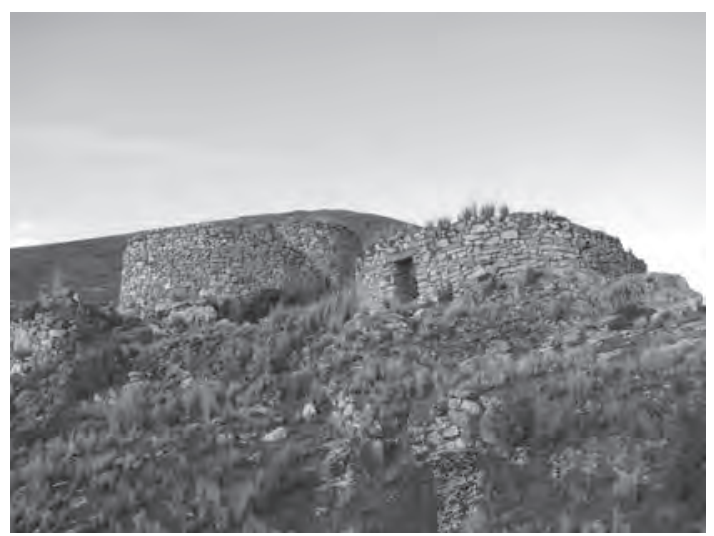

Figura 45. Edificio habitacional de planta circular de Chaquimarca.

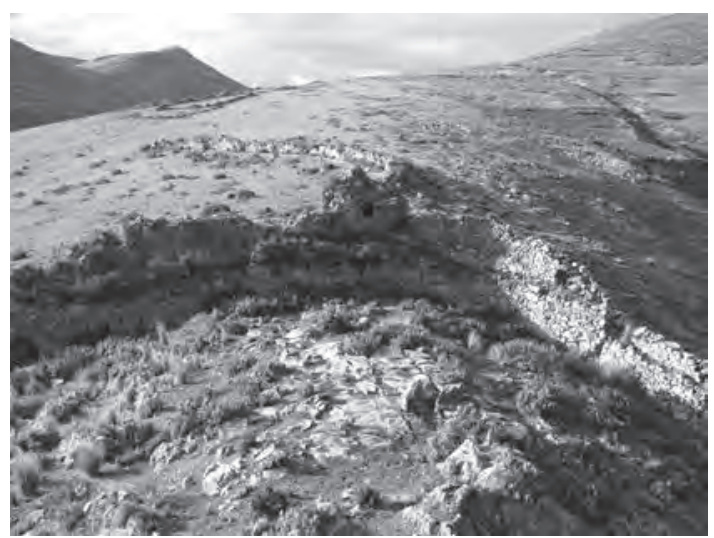

Figura 44. Vista de los edificios funerarios adosados a las murallas de Chaquimarca.

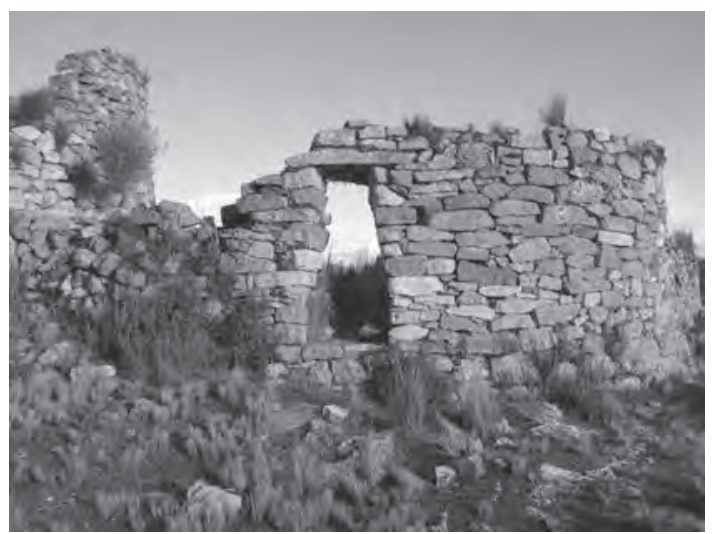

Figura 46. Edificio habitacional de planta circular de Chaquimarca.

En Chaquimarca también se desarrolló la actividad agropecuaria, pues hacia el oeste del sitio se encuentra un sistema de terrazas cultivables arqueológicas bien definidas, las cuales se extienden 200 o 300 m hacia el río Palcamayo. Además en la zona noreste también se encuentran campos de cultivo, las cuales están ubicadas sobre una lomada de relieve terroso apto para la agricultura. Observando la disposición y las alturas donde ubican estas tierras de cultivo, podemos determinar que en Chaquimarca se desarrolló dos tipos de agricultura. El primer tipo de agricultura, es la de altura, la cual se llevó a cabo en la colina cultivable ubicada al noreste de Chaquimarca, pues estas tierras se ubican sobre los $4000 \mathrm{msnm}$. El segundo tipo de agricultura se habría dado en las terrazas cultivables arqueológicas, ubicadas al oeste de Chaquimarca, en las cuales se produciría la agricultura típica de la zona quechua.

En Chaquimarca también se desarrolló la actividad ganadera, pues al noroeste del sitio se encuentran algunos basamentos de corrales, los cuales se encuentran muy deteriorados, pero aun es posible distinguirlos desde zonas altas. Además los pastores de Chaquimarca, habrían pastado su ganado en las punas ubicadas al norte de la quebrada Cocón, donde hay unas extensas pampas y abundantes recursos hídricos, como bofedales y el lago Cocón.

Chaquimarca habría interactuado con los asentamientos ubicados en la zona norte del valle de Palcamayo como Anashpata, Huagapo y Yaumanpata. También tuvo estrecha relación con Moralla- 
punta, pues se ubica a solo un par de kilómetros descendiendo por la quebrada de Cocón. Por ubicarse en la zona central del valle de Palcamayo, también se habría relacionado con los asentamientos ubicados en la zona sur del valle, como Yanamarca y Pichqamarca; así mismo pudieron haber llegado sus lazos de interacción hasta la región de Acobamba y en especial con los sitios de Huarimarca y Vilcabamba. Vilcabamba presenta una muralla perimetral similar al que observamos en Chaquimarca, pues también muestra los edificios de planta cuadrangular adosados a la muralla, y presenta evidencia de haber cumplido una función funeraria; esto nos indica que este tipo de muralla perimetral con edificio funerario adosado es una característica arquitectónica Tarama.

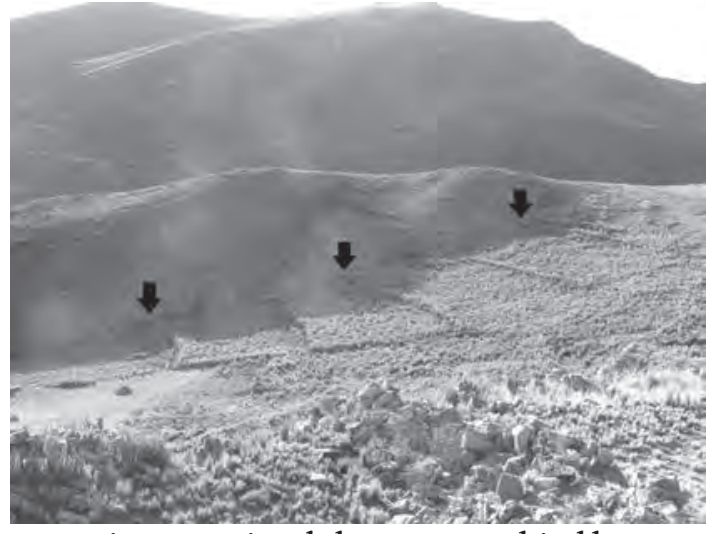

Figura 47. Vista de las terrazas cultivables arqueológicas de Chaquimarca.

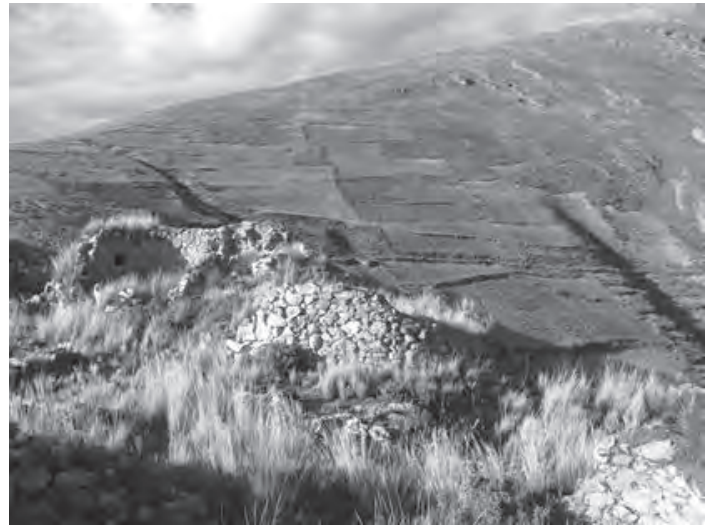

Figura 48. Vista de las tierras de cultivo de puna asociadas a Chaquimarca.

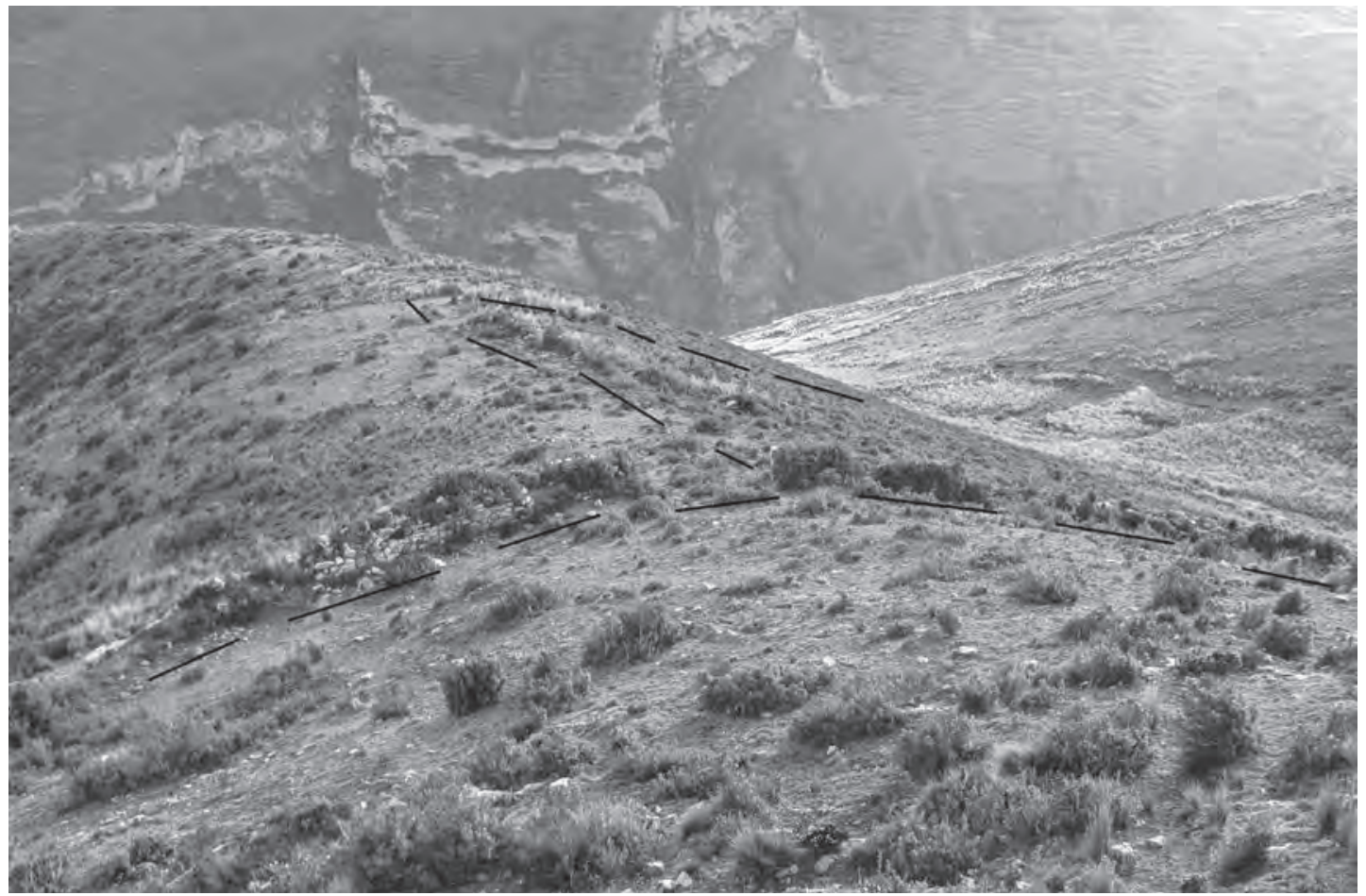

Figura 49. Vista de los basamentos de los corrales de Chaquimarca, en muy mal estado de conservación. 


\section{YURACMARCA}

Este asentamiento se ubica al noroeste del distrito de La Unión Leticia en la provincia de Tarma, en la cumbre del cerro Yuracmarca, a $4173 \mathrm{msnm}$. En Yuracmarca existe un sistema de terrazas que ayuda a nivelar el relieve irregular de la cumbre del cerro, siendo más notorio en la zona norte donde se encuentra una elevación.

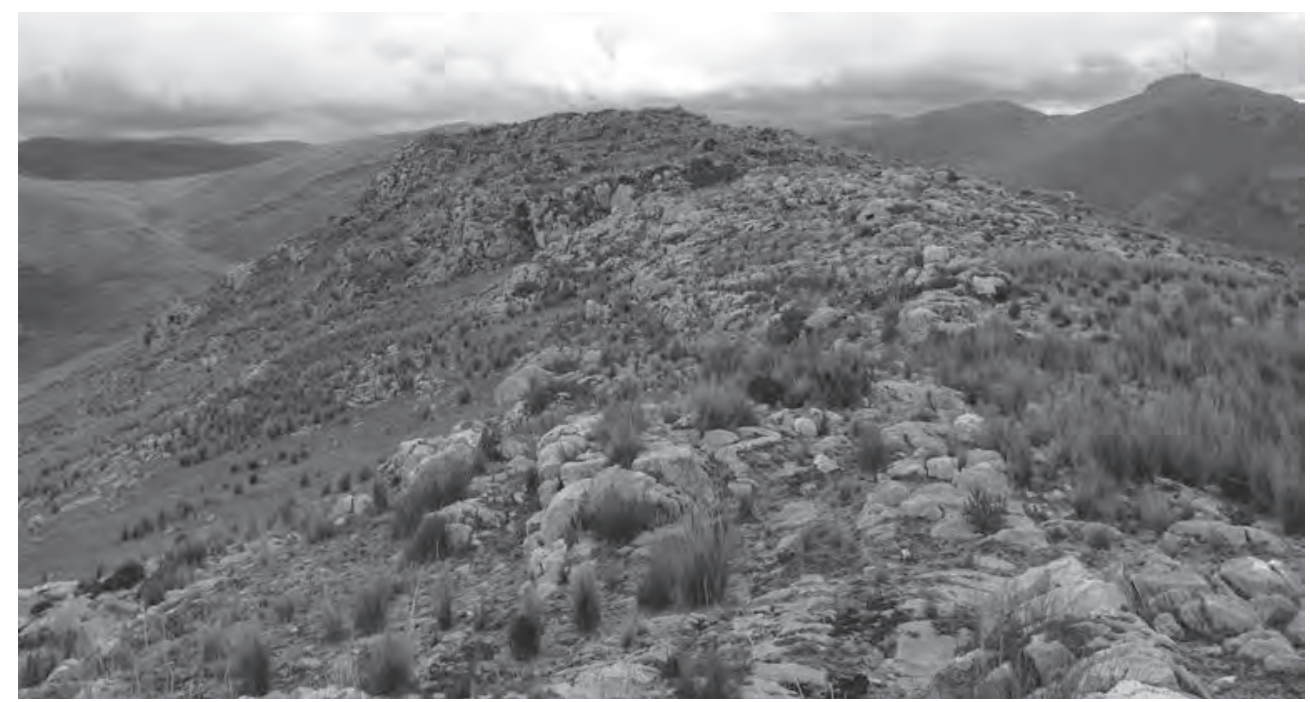

Figura 50. Vista panorámica de Yuracmarca.

Yuracmarca presenta edificios de planta circular, asociado a patios de forma rectangular, los cuales son muy estrechos, y muestran una disposición arquitectónica típica de los tarama. Los recintos circulares tienen un diámetro de 3 a $4 \mathrm{~m}$, con accesos de $0,70 \mathrm{~m}$ de ancho y aproximadamente $0,80 \mathrm{~m}$ de alto.

En Yuracmarca también encontramos pequeñas edificaciones de planta rectangular, las cuales tendrían una función funeraria, pues en su interior se encuentra material óseo humano. Debemos señalar que las edificaciones en Yuracmarca están hechas de roca caliza y mortero arcilloso.

Los pobladores de Yuracmarca también evidencian haber desarrollado actividad agropecuaria, pues hacia la zona sur del asentamiento se pueden evidenciar los cimientos de amplios corrales, los cuales tiene un diámetro de 20 y $30 \mathrm{~m}$. Además los pastores de este sitio habrían pastado su ganado por los alrededores de este cerro y en las pampas de Condorcocha ubicadas a cinco kilómetros de Yuracmarca.

La agricultura se habría llevado a cabo en la zona oeste de este asentamiento, donde existen amplias zonas agrícolas, las cuales se expanden por toda las ladera oeste del cerro Yuracmarca. Además al suroeste de Yuracmarca se expanden amplias zonas de cultivo de quebrada, las cuales se encuentran a solo dos kilómetros de distancia. En Yuracmarca también encontramos una wuanash (chancador de tierra), la cual está hecha de granito pero se encuentra en muy mal estado, pues solo encontramos la mitad de esta herramienta lítica, básica para la actividad agrícola.

Yuracmarca habría formado sus lazos de interacción con todos los asentamientos que se encuentran dentro de la región de La Unión Leticia. Pues los sitios como Quipamarca, Marca-Marca, Punchaumarca, Shanshamarca y Kutumarca se encuentran a muy pocos kilómetros de distancia entre sí, haciendo muy cómoda su interacción. Además pudieron haber tenido interacción con los asentamientos ubicados en el valle de Palcamayo y de Tarma, pues todos estos asentamientos guardan una clara filiación cultural Tarama. 


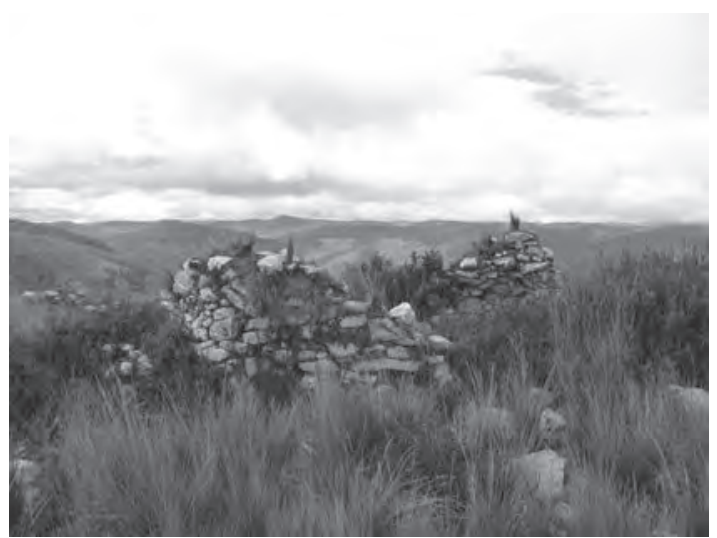

Figura 51. Edificio de planta circular de Yuracmarca.

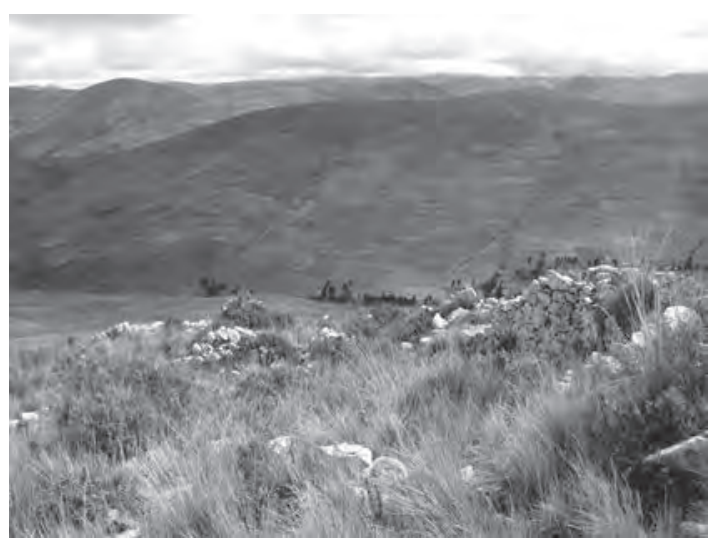

Figura 53. Vista de la zona agrícola de Yuracmarca.

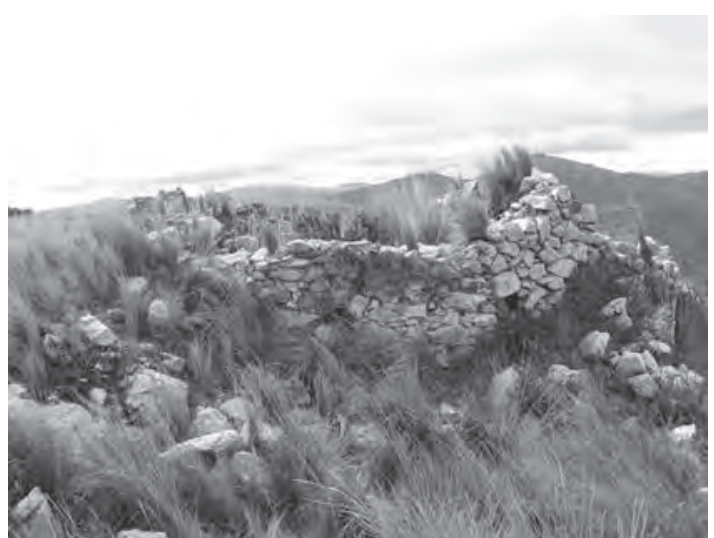

Figura 52. Edificio de planta circular de Yuracmarca.

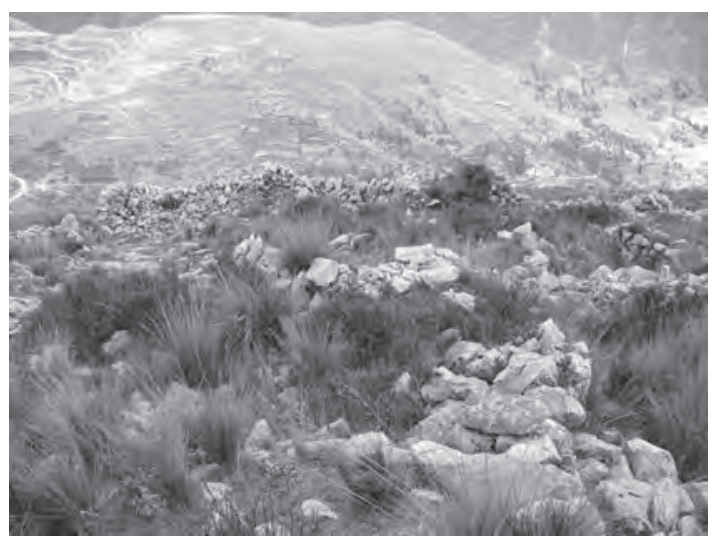

Figura 54. Basamentos de algunos corrales de Yuracmarca.

\section{QUIPAMARCA}

Quipamarca es un asentamiento tarama ubicado entre las localidades de Limapuquio y Cari al norte del poblado de Condorcocha, en el distrito de La Unión Leticia en Tarma. Este asentamiento se ubica sobre el cerro Quipamarca a $4320 \mathrm{msnm}$, entre afloramientos rocosos y un relieve irregular. Este asentamiento presenta muchas terrazas que ayudan a nivelar el terreno, además las terrazas que se ubican en las zonas bajas también funcionan como murallas perimetrales.

Quipamarca presenta edificaciones de planta circular, asociadas a un patio de forma cuadrangular y rectangular. Estos recintos tiene un diámetro de 3 y $4 \mathrm{~m}$, los muros son de dos caras y se encuentran unidos por argamasa arcillosa.

En la zona central de este asentamiento encontramos edificaciones funerarias, con techos de lajas entrecruzadas y sostenidas por ménsulas, estas edificaciones miden 0,90 m de alto y tiene techos planos; estas edificaciones de función funeraria son similares a las vistas en Anashpata. También vemos edificación de planta cuadrangular de dos pisos y techo abombado, con ventanales de forma trapezoidal en cada piso. Además, existen recintos funerarios adaptados en afloramientos rocosos, por lo general estos son muy pequeños con acceso de $0,50 \mathrm{~m}$ de alto.

En este asentamiento es muy evidente el desarrollo agropecuario, pues hacia el oeste del asentamiento podemos observar un sistema de amplios y numeroso corrales, los cuales presentan un diá- 


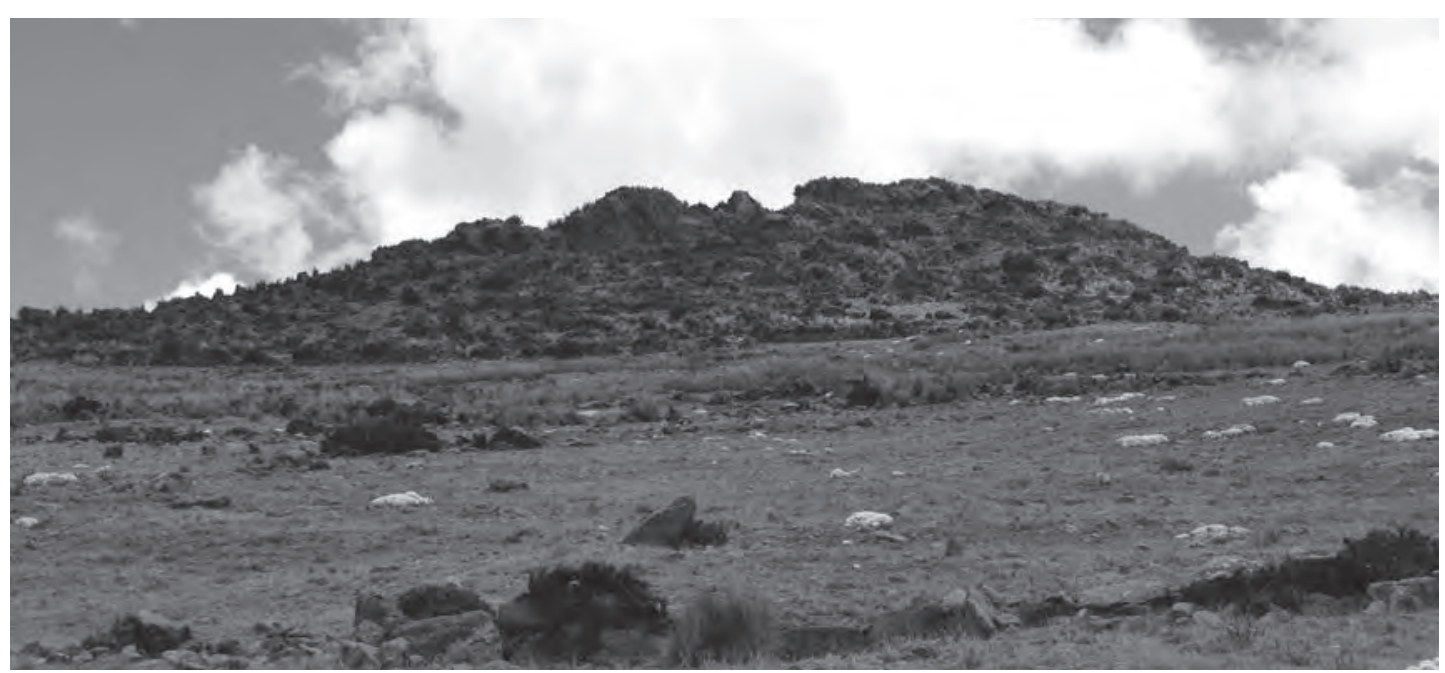

Figura 55. Vista panorámica de Quipamarca.

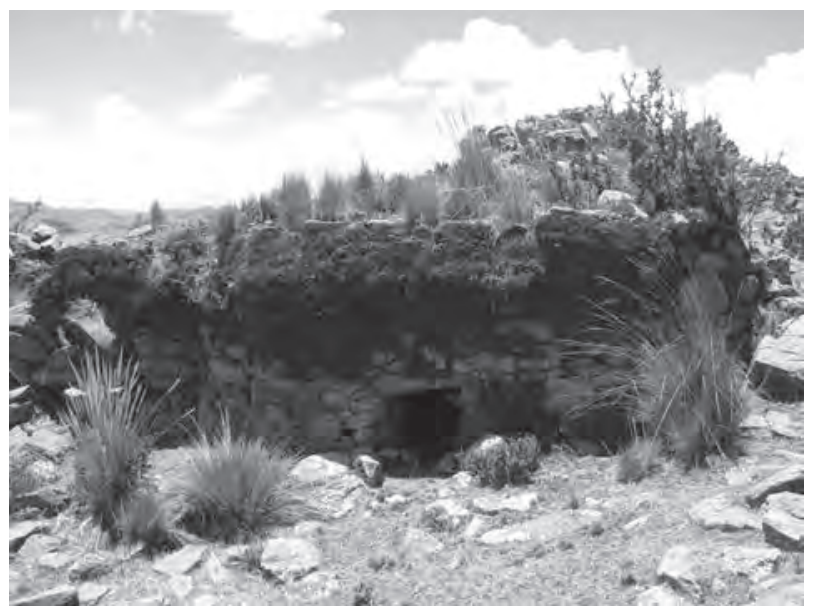

Figura 56. Edificio funerario de planta cuadrangular de Quipamarca.

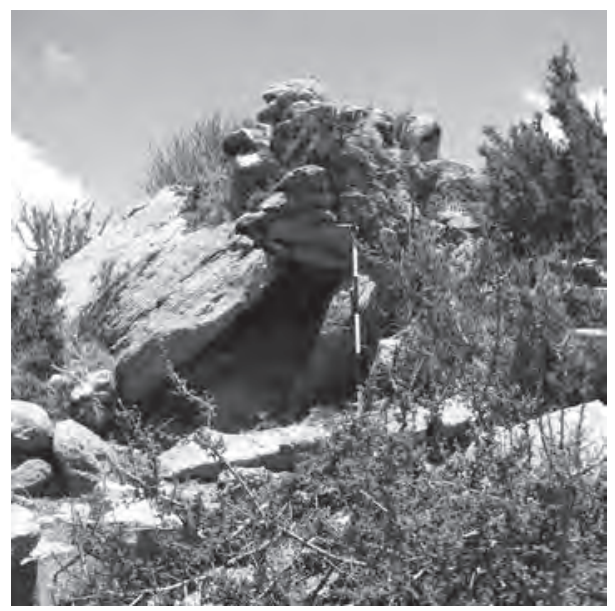

Figura 57. Recinto funerario adosado a una afloración rocosa de Quipamarca.

metro de 20 y 30 m; por la cantidad de corrales podemos determinar que tuvieron muchas cabezas de ganado a su disposición. En esta zona, como en Lomo Largo, habitan numerosas vicuñas, pues cuando visitamos este sitio, observamos una estampida de ellas, con el macho a la cabeza. Como esta región se encuentra cerca a las pampas de Junín, es muy lógico que estos animales recorran estas tierras. Además esta región es apta para el pastoreo, pues cuenta con mucho forraje y bofedales.

La agricultura también habría sido practicada por los pobladores de Quipamarca, pues en las zonas bajas del cerro Quipamarca en dirección de los poblados de Limapuquio y Cari, se extienden amplias zonas agrícolas, que hasta la actualidad siguen siendo explotadas. Esta evidencia nos indicaría que la población de Quipamarca tuvo una producción agrícola de puna.

Como Quipamarca se encuentra dentro de la región de La Unión Leticia, habría formado lazos de interacción con los asentamientos tarama más cercanos como Yuracmarca, Marca-Marca, Punchaumarca, Shanshamarca y Kutumarca. Además Quipamarca habría interactuado con los taramas del Valle de Palcamayo y con el sitio de Chuyac, este último ubicado en la región sur de San Pedro de Cajas. 


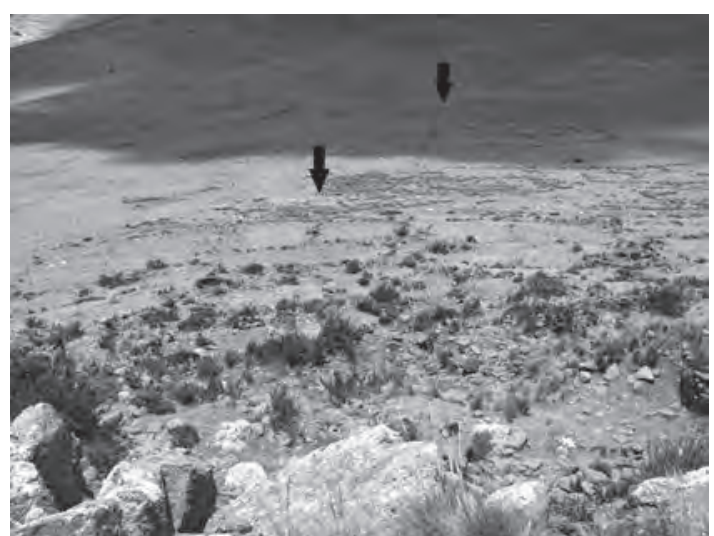

Figura 58. Vista de los corrales de Quipamarca.

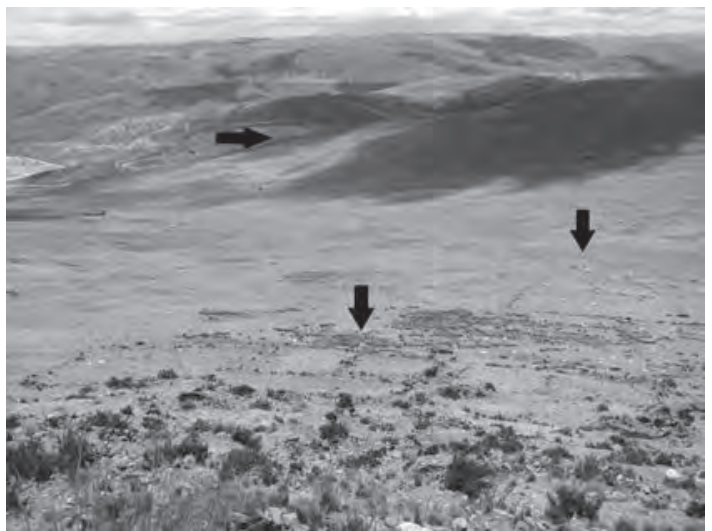

Figura 59. Vista de los corrales en la parte inferior y vista de las tierras agrícolas en la parte superior, todas directamente asociadas a Quipamarca.

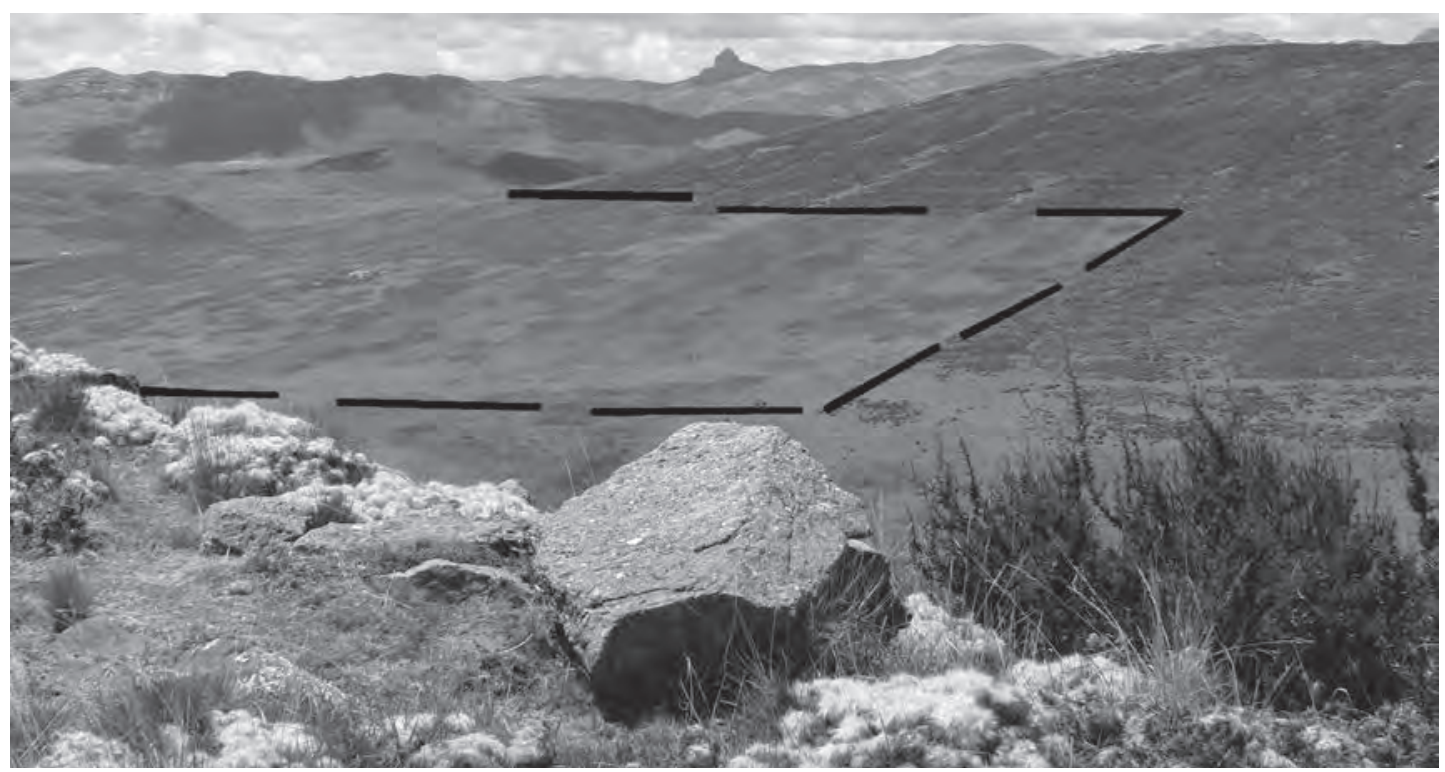

Figura 60. Zona agrícola de Quipamarca.

\section{ANÁLISIS DE LAS PROSPECCIONES ARQUEOLÓGICAS}

Durante las prospecciones arqueológicas registramos mucha evidencia empírica, con la cual pudimos identificar características propias y casi similares que desarrollaron los guancas y taramas; pero siempre diferenciándose como manifestaciones culturales autónomas pre-Tawantinsuyo.

Analizando los sitios arqueológicos guancas y taramas, hemos observado que estos presentan un patrón de asentamiento concentrado. Estos asentamientos se ubican sobre las cimas de los cerros y en las zonas altas de las quebradas. Pero también debemos mencionar que existen sitios guancas y taramas como Ocullacta, Chuctumarca, Cutu Cutu de Huanchar, Hualhuascoto, Muqui y Vilcabamba que se encuentran en las laderas medias y altas de las faldas de los cerros que rodean los valles. También observamos que todos estos asentamientos se encuentran asentados sobre terrenos rocosos, en donde la roca madre está casi expuesta. 
Los pobladores de estos asentamientos guancas y taramas habrían ocupado todas estas áreas, ya mencionadas, para evitar las inundaciones, las cuales se producen en las áreas bajas de los valles durante las épocas lluviosas. Además ocupando estas áreas, estos asentamientos dejaron libres las zonas terrosas y fértiles para la agricultura, pues estas tierras se ubican en las partes bajas de los valles, en las áreas medias y bajas de las quebradas y en las zonas llanas de las punas.

Al estudiar con detenimiento la arquitectura guanca y tarama, observamos que en estos edificios se utilizó la roca caliza y la arcilla calcárea como material constructivo. Además en los asentamientos guancas y taramas, notamos que los edificios habitacionales presentan plantas de forma circular con 4 o $5 \mathrm{~m}$ de diámetro, con muros de doble cara que miden entre 40 y $50 \mathrm{~cm}$ de espesor. Estos edificios habitacionales presentan accesos de forma trapezoidal casi rectangular, con 80 centímetros en la base y $70 \mathrm{~cm}$ en la parte superior. Estos edificios habitacionales guancas y taramas son muy parecidos en su forma y gracias a los datos que pudimos registrar en el sitio arqueológico guanca de Muqui en Muquillaullaos-Jauja, hemos podido evidenciar que estos edificios estuvieron enlucidos con material arcilloso calcáreo, este dato nos ayuda a inferir que estos recintos habitacionales, de planta circular, estuvieron enlucidos por una capa arcillosa durante su ocupación original (Navarro 2012).

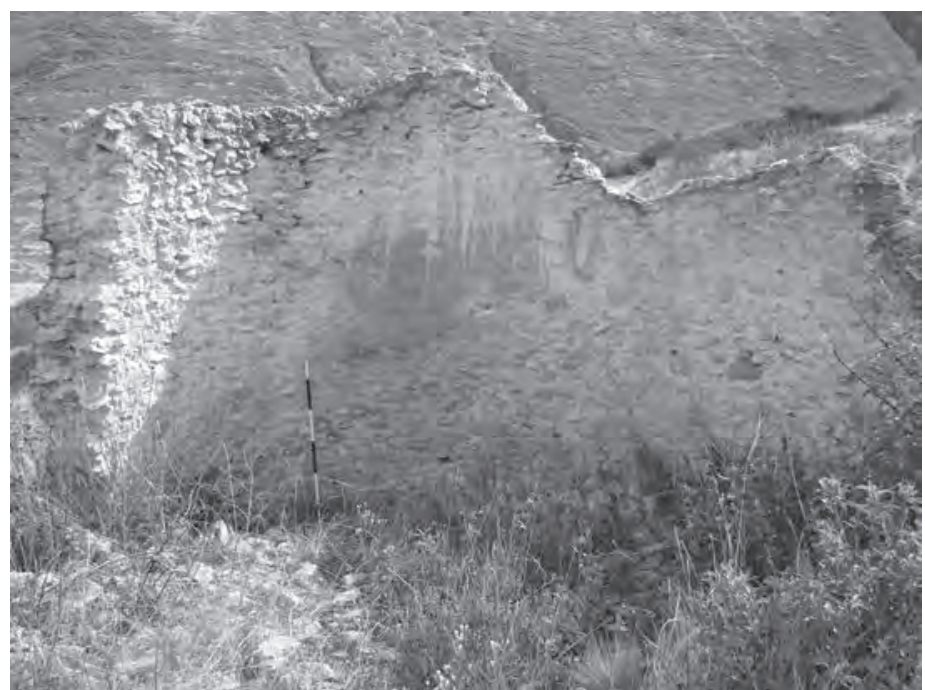

Figura 61. Vista de un edificio habitacional de Muqui, en donde se evidencia el enlucido hecho de arcilla calcárea.

La disposición de los edificios habitacionales de planta circular de los guancas y taramas presentan claras diferencias. Los edificios de planta circular de los guancas se encuentran agrupados entre cuatro, tres o dos edificios habitacionales asociados a un patio ovalado; esta disposición arquitectónica la llamamos «complejo arquitectónico Guanca» y es una característica propia de esta cultura. Mientras que los edificios de planta circular de los taramas se encuentran agrupados entre tres, dos o un edificio habitacional asociados a un patio de forma rectangular o cuadrangular, siendo esta disposición muy característica de los «complejos arquitectónicos Tarama» (Navarro 2012). Además hemos podido apreciar que dentro de algunos de estos «complejos arquitectónicos taramas» existen edificios funerarios, como lo podemos apreciar claramente en Quipamarca, Aujsaypan y Maysalpul.

Como muchos de los asentamientos guancas y taramas se encuentran asentados sobre relieves irregulares, en estos sitios podemos apreciar sistemas ordenados de terrazas, los cuales ayudan a formar relieves aptos para las construcciones y a generar pasajes de comunicación dentro de los sitios.

En muchos asentamientos guancas y taramas hemos podido registrar murallas perimetrales. En algunos casos las murallas rodean casi todo el sitio, como en Tunanmarca y Aujsaypan. Mientras que en otros solo se presentan en algunos sectores, como en Chaquimarca, Vilcabamba, Anashpata, Huacjlasmarca y Anjushmarca. Dentro de este punto debemos mencionar una característica importante que presentan las murallas perimetrales de los asentamientos taramas, en estas murallas hemos podido identificar edificios funerarios adosados a estas murallas. Estos edificios funerarios adosados a las murallas, presentan formas de pequeñas cámaras y de grandes torreones de hasta $4 \mathrm{~m}$ de alto, dichas edificaciones las podemos apreciar en Chaquimarca, Santa Ana, Vilcabamba y Luychumarca. 


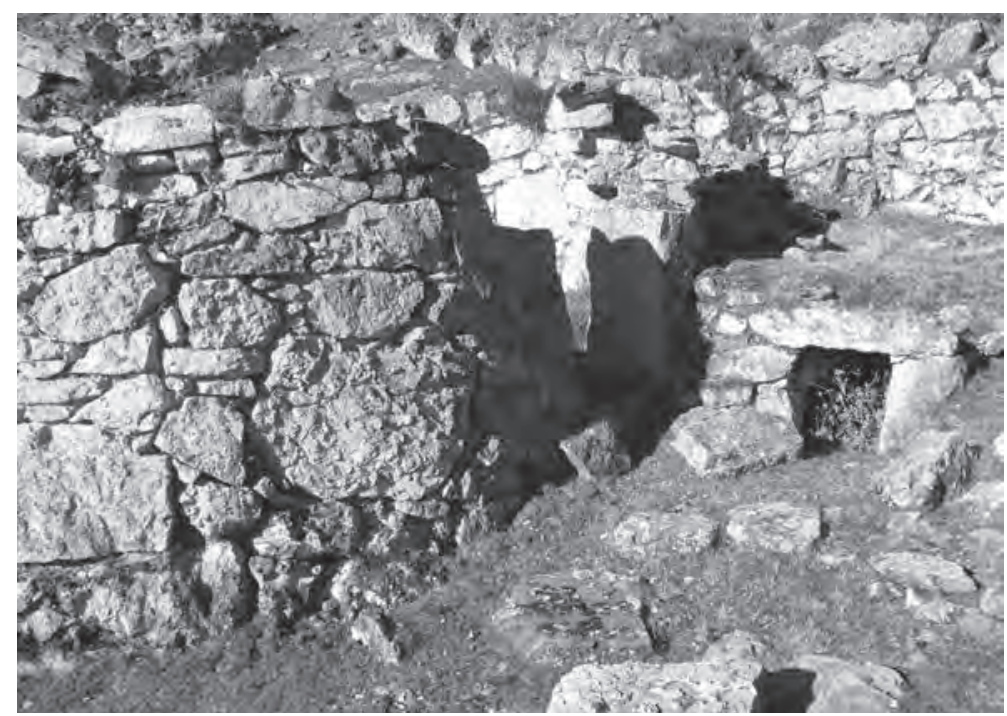

Figura 62. Vista de un edificio funerario dentro de un complejo arquitectónico Tarama. Sitio de Maysalpul.

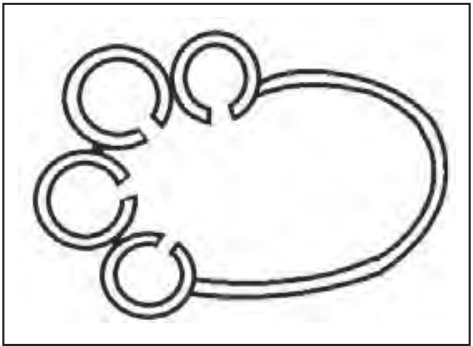

Figura 63. Gráfico del Complejo Arquitectónico Guanca.

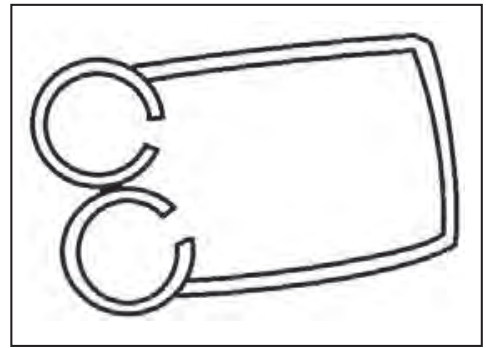

Figura 64. Gráfico del Complejo Arquitectónico Tarama.

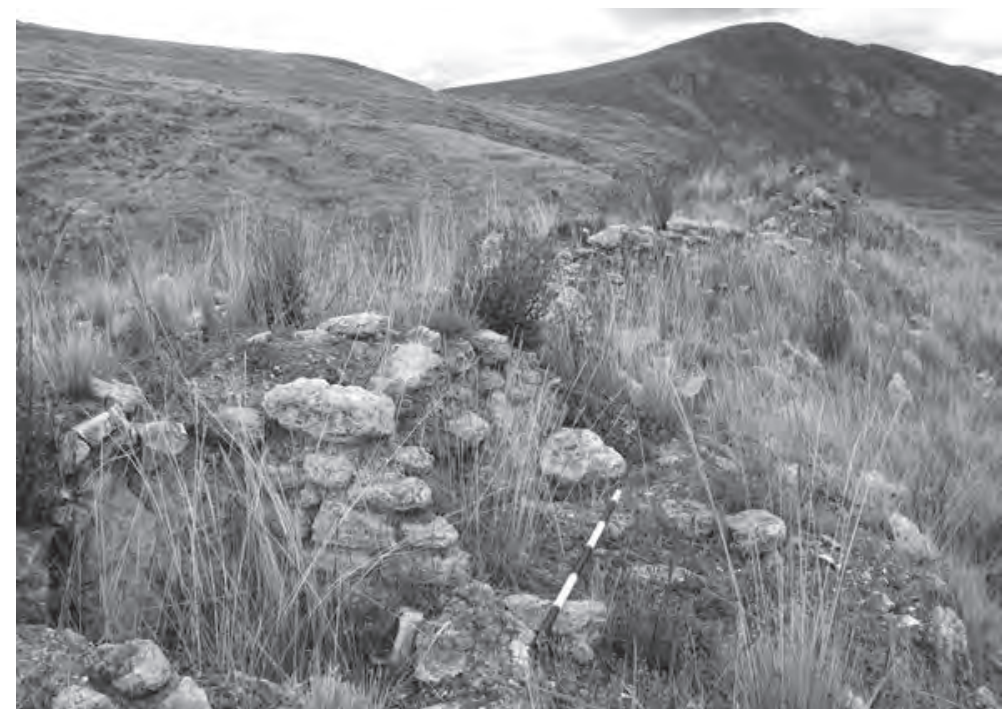

Figura 65. Vista de las cámaras funerarias en las murallas externas del sitio de Luchuymarca. 
En los sitios arqueológicos que hemos estudiado y expuesto en este trabajo, encontramos muchos corrales. Los corrales de los guancas y taramas presentan formas ovaladas y cuadrangulares. Estos corrales poseen un diámetro de 20 o $30 \mathrm{~m}$ y se encuentran muy agrupados. Debido a las investigaciones en Anjushmarca, hemos podido determinar que los corrales ovalados corresponderían a un primer momento constructivo, alrededor de la primera parte del periodo del Intermedio Tardío; mientras que los corrales de forma cuadrangular corresponderían a un segundo momento constructivo, el cual se daría a mediados de Intermedio Tardío. También hemos podido notar que los corrales nunca se encuentran aislados, siempre están en directa asociación con los edificios habitacionales. Entre los corrales ubicamos algunos edificios habitacionales, los cuales serían ocupados por los cuidadores del ganado. Es importante señalar que los corrales no sólo se encuentran en los asentamientos ubicados en la puna, sino también en los sitios ubicados en la región quechua, lo cual nos demuestra que los guancas y taramas asentados en la región puna y quechua practicaron la ganadería.

En cada asentamiento guanca y tarama que visitamos, durante nuestras prospecciones, pudimos hallar muestras de cerámica en superficie. En los asentamientos taramas observamos el tipo de cerámica San Blas. El cual está presente en toda esta región Tarama y Chichaycocha. Debido a las escasas investigaciones llevadas a cabo con minuciosidad sobre los taramas, aún no se ha podido definir si esta cultura elaboro algún tipo de cerámica propia, pues la cerámica San Blas sería originaria de la región Chinchaycocha. Mientras que en la superficie de los asentamientos guancas, pudimos evidenciar la cerámica «guanca», identificando los tipos de cerámica Guanca I, Guanca II y Guanca III/ Tawantinsuyo (Navarro 2012). Esta clasificación de la cerámica guanca la explicaremos en el punto de las excavaciones arqueológicas.

\section{Excavaciones arqueológicas en Anjushmarca: EXPOSICIÓN Y ANÁLISIS DE LOS DATOS}

Durante las prospecciones arqueológicas registramos datos importantes para nuestra investigación, pero para indagar mejor sobre el desarrollo económico y social de los guancas y taramas pre-Tawantinsuyo, decidimos realizar excavaciones arqueológicas en el sitio de Anjushmarca; si bien solo realizamos este tipo de trabajos en un sitio guanca, la evidencia que hallamos en este asentamiento también nos ayudó a comprender mejor y a relacionar datos empíricos de los taramas. En esta etapa de nuestra investigación pudimos registrar nueva evidencia empírica de contextos cerrados, los cuales nos ayudaron a expandir nuestro conocimiento sobre el desarrollo agropecuario y social de estas dos culturas Centro Andinas, en relación a los Andes centrales.

La metodología usada durante las excavaciones arqueológicas en Anjushmarca, tuvo como objetivo hallar la mayor cantidad de evidencia arqueológica posible, la cual nos indique aspectos importantes sobre la organización social y económica de los guancas; y así mismo, con estos datos, poder identificar aéreas de actividad en Anjushmarca, ya sean domesticas, productivas y funerarias. Para un mejor análisis de los hallazgos arqueológicos en relación al sitio, decidimos dividir a Anjushmarca en dos grades áreas, Colina I y II, y dentro de ellas definimos cuatro sectores de trabajo, de los cuales solo trabajamos tres y dejamos una para próximas investigaciones.

Durante las excavaciones arqueológicas en Anjushmarca, hallamos mucha evidencia de cerámica Guanca. La cual la clasificamos en cerámica Guanca I, Guanca II y Guanca III/Tawantinsuyo. La cerámica Guanca I presenta pasta blanca y engobe color blanco, con decoraciones pictóricas punteadas, lineales, curvas y rectas. Todas estas decoraciones fueron hechas en color negro y se habrían hecho con un tipo de hisopo. Esta cerámica también presenta la decoración cara gollete con ojos y boca en forma de granos de café. La cerámica Guanca II que hallamos en Anjushmarca presenta dos tipos. El primer tipo muestra engobe color rojo, con decoraciones lineales y punteadas en color negro y blanco. Esta cerámica presenta decoraciones en cara gollete similares a las que muestra la cerámica Guanca I, y a este tipo de cerámica la denominamos cerámica Guanca II con «Engobe Rojo». El segundo tipo pre- 


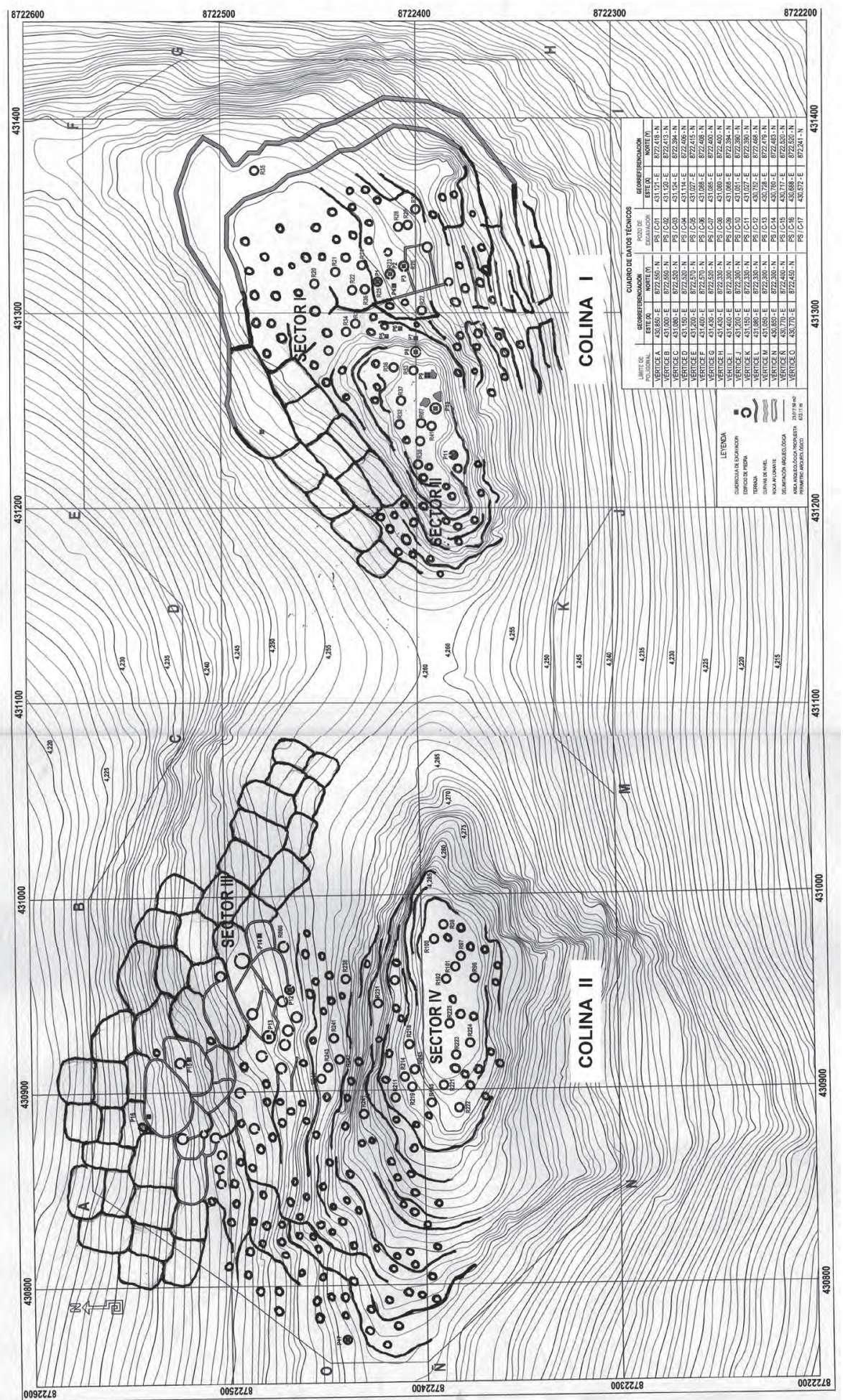

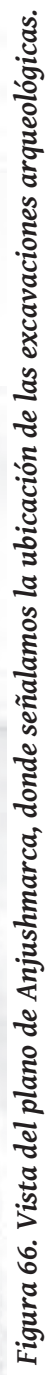


senta un engobe micáceo y también muestra decoraciones pintadas como las que se evidencia en la cerámica Guanca II con «Engobe Rojo», pero en este tipo no evidenciamos decoraciones cara gollete; a este segundo tipo de cerámica la llamamos Guanca II con «Engobe Micáceo» (Navarro 2012).

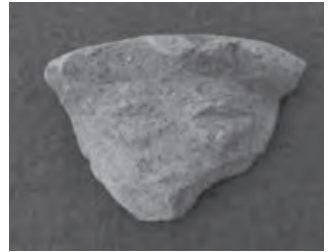

Figura 67. Vista de la Cerámica Guanca I. Decoracion cara gollete.

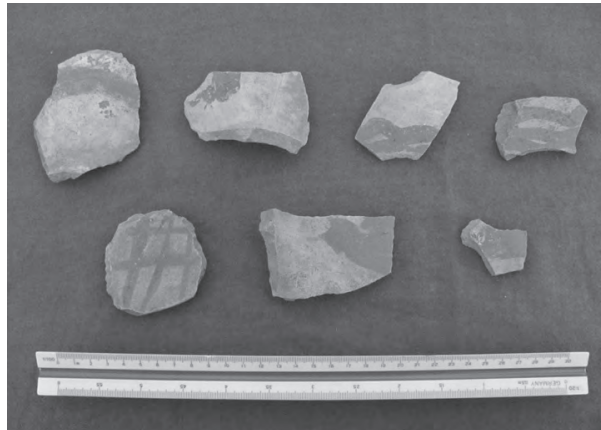

Figura 68. Vista de la Cerámica Guanca I. Decoraciones pictóricas.

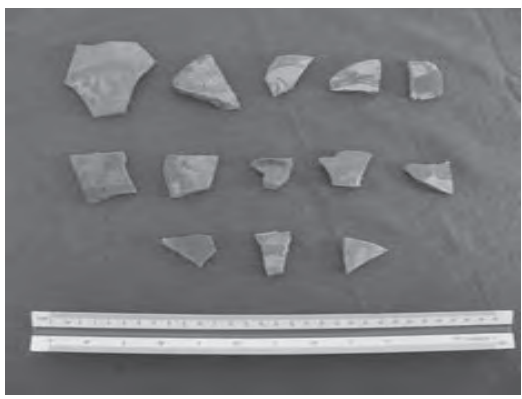

Figura 70. Vista de la cerámica Guanca II con Engobe Rojo. Decoraciones pintadas.

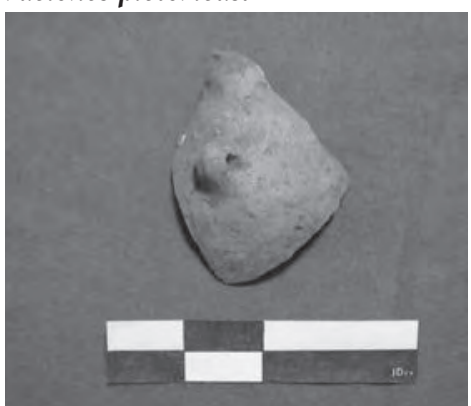

Figura 71. Vista de la Cerámica Guanca II con Engobe Rojo. Fragmento detallado de una vasija.

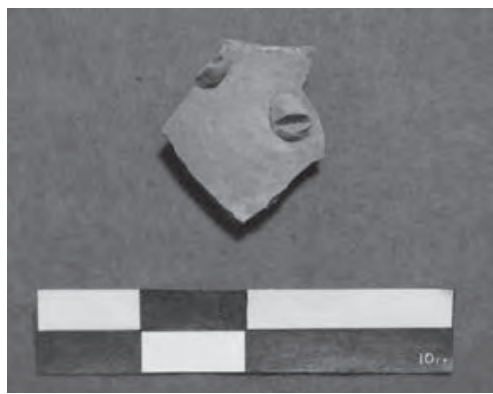

Figura 69. Vista de la Cerámica Guanca II con Engobe Rojo. Decoración cara gollete.

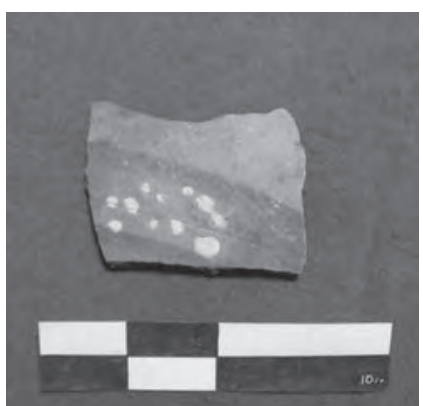

Figura 72. Vista de la Cerámica Guanca II con Engobe Micáceo. Decoración pintada.

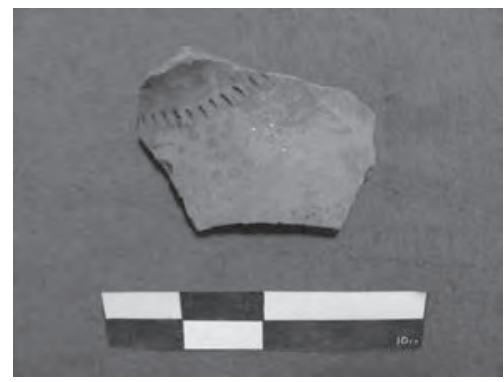

Figura 73.Vista de la Cerámica Guanca II con Engobe Micáceo. Decoración pintada y punteada.

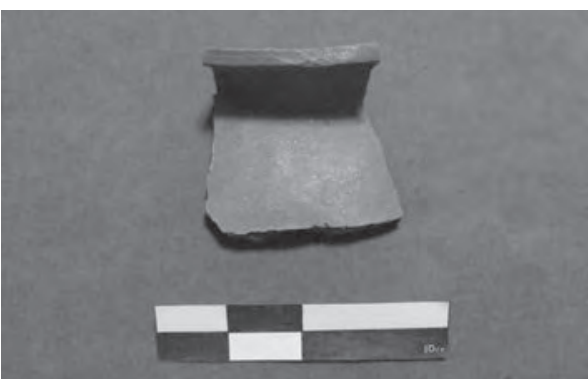

Figura 74.Vista de la Cerámica Guanca II con Engobe Micáceo. Detalle del pulido.

En las excavaciones arqueológicas también descubrimos cerámica Tawantinsuyo, la cual denominamos Guanca III/Tawantinsuyo. Esta cerámica fue elaborada en la región guanca, pero presenta características típicas de la cerámica Tawantinsuyo. Por último también hallamos en Anjusharca, pero en menor medida, cerámica San Blas; la cual no es propia de los guancas. Esta cerámica San Blas tendría su origen en la región del Chinchaycocha y su uso se habría expandido por toda la región tarama, es por eso que a esta cerámica se la relaciona con las culturas Tarama y Chinchaycocha (Navarro 2012). 


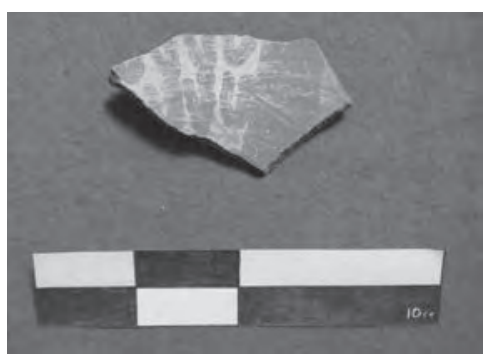

Figura 75. Vista de la cerámica San Blas.

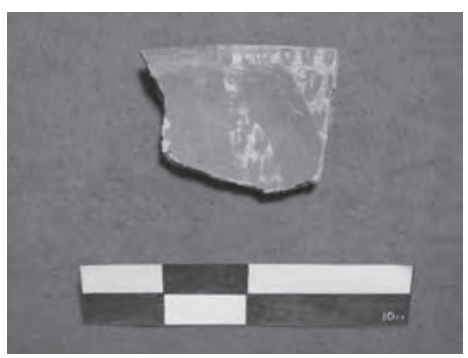

Figura 76. Vista de la cerámica San Blas.

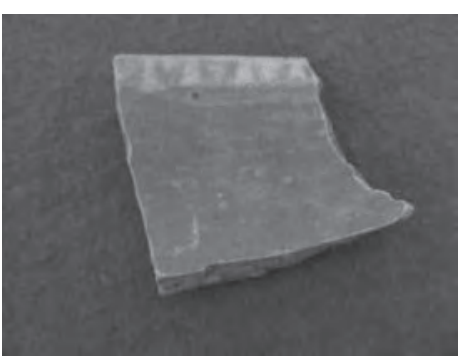

Figura 77. Vista de la cerámica San Blas.

Al finalizar el estudio de la cerámica guanca hallada en Anjushmarca, hemos podido determinar que la cerámica Guanca I habría aparecido a inicios del Intermedio Tardío, luego esta decaería en su uso a medidos de este mismo periodo. Ya a mediados del Intermedio Tardío, la cerámica Guanca II tendría más presencia en su uso, el cual duraría hasta el tiempo de la ocupación Tawantinsuyo. Durante la ocupación Tawantinsuyo, en todo el territorio Guanca, la cerámica Guanca III/Tawantinsuyo dominaría en su producción. Es importante señalar que en las excavaciones hallamos los tres tipos de cerámica guanca en directa asociación, lo cual nos demuestra que los tipos de cerámica Guanca I y II no desaparecieron durante la ocupación Tawantinsuyo, solo decayeron en su producción (Navarro 2012).

La cerámica San Blas descubierta en Anjushmarca, también fue hallada directamente asociadas a la cerámica Guanca. Pero la cantidad de cerámica San Blas encontrada fue muy poca, lo cual nos indica que este sitio no tuvo una ocupación tarama o chinchaycocha. La presencia de este tipo de cerámica en el sitio se debería a causa de la interacción que tuvieron los guancas y taramas.

Nuestras excavaciones arqueológicas en Anjushmarca (Navarro 2012), los estudios arqueológicos realizados en la región de Ricrán (Perales 2011) y las investigaciones llevadas a cabo en el sitio Tarama de Cashamarca (Calderón 2009), nos confirman que los taramas y guancas tuvieron una fluida interacción y que no se aislaron entre sí. Pues durante nuestras investigaciones en Anjushmarca hallamos muestras de cerámica San Blas, lo cual indicaría que los guancas de Anjushmarca interactuaron con los taramas asentados en el sitio de Capia y Huanri, en el valle de Tarma (Navarro 2012). Las investigaciones llevadas a cabo en Ricrán también demuestran que los guancas interactuaron con los taramas, probablemente de la región de Tapo. Además los estudios en Cashamarca, evidenciaron la presencia de contextos funerarios taramas directamente asociados a contextos funerarios guancas, lo cual indica una fuerte interacción entre estas dos culturas centroandinas.

En las excavaciones planteadas al pie y sobre el peñasco de la Colina I de Anjushmarca, pudimos hallar evidencia funeraria. Sobre este peñasco, en la Cuadrícula 9, hallamos los basamentos de un edificio funerario de base cuadrangular, que en su interior presentaba pequeñas cámaras internas; mientras que al pie del peñasco, en la Trinchera 7, hallamos una vasija ritual asociada a material óseo humano y de camélido. Además en la cima de la Colina II, sobre el peñasco, identificamos los basamentos de un edificio funerario similar al que hallamos en la Cuadrícula 9; y al oeste de esta última Colina también evidenciamos los basamentos de un edificio funerario de planta circular y las bases derruidas de un osario de base rectangular. Así mismo, como ya mencionamos líneas arriba en la parte de las prospecciones arqueológicas, también identificamos actividad funeraria en las cavernas de las Colinas I y II de Anjushmarca.

En las excavaciones arqueológicas también registramos mucho material óseo de camélido, el cual estaba calcinado y triturado. Esto nos indica que los pobladores de Anjushmarca tuvieron mucha ingesta de estos animales, los cuales habrían sido cocidos en brasas y triturados los huesos para extraerles el tuétano. Por la gran cantidad de corrales presentes en Anjushmarca podemos determinar 
que los pobladores de este sitio tuvieron este alimento en abundancia. Además en las excavaciones realizadas en el área de los corrales de Anjushmarca, pudimos hallar osamentas de camélidos de distintos tamaños. Lo cual nos indica que dentro de estos corrales hubo un especial cuidado con el ganado, separando a los machos de las hembras preñadas para evitar abortos, alejando a los animales enfermos de los sanos y separando a las pequeñas crías de los adultos; todo esto con el objetivo de optimizar la producción ganadera.

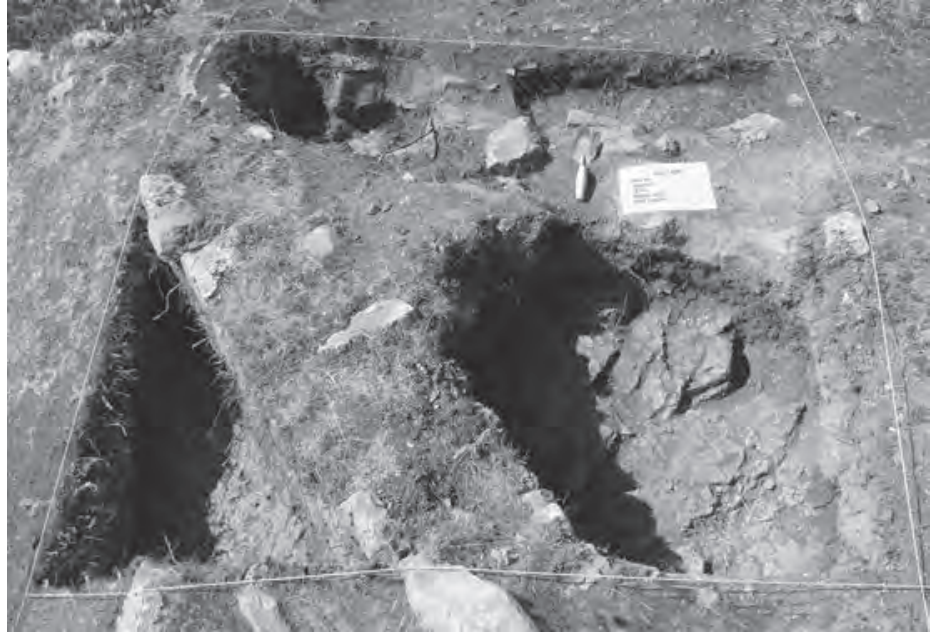

Figura 78. Vista de los basamentos del edificio funerario hallado en los trabajos de la Cuadrícula 9.

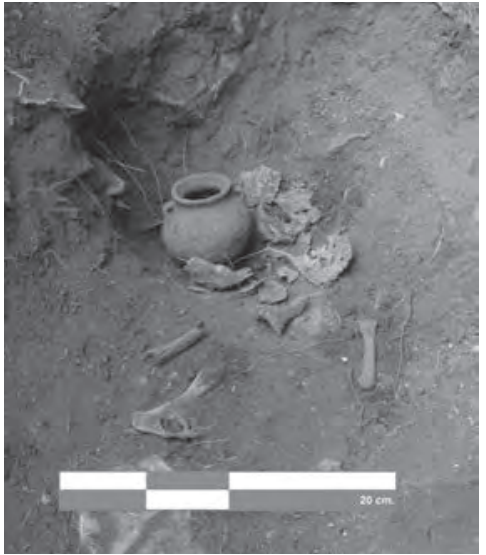

Figura 79. Vista de la vasija Guanca I hallada en directa asociación con restos óseos humano y de animal en la Trinchera 7 de nuestras excavaciones arqueológicas.

Por último, en la Cuadrícula 15 de nuestras excavaciones, pudimos hallar un instrumento lítico llamado Wuanash o chancador de tierra, el cual es usado en la actividad agrícola para remover la tierra (Navarro 2012). Este instrumento lítico nos demuestra que los pobladores de puna también se dedicaron a la agricultura de altura, pues el sitio además de ubicarse a $4280 \mathrm{msnm}$, está rodeado de óptimas tierras de cultivo, las cuales ya expusimos en el punto de las prospecciones arqueológicas.

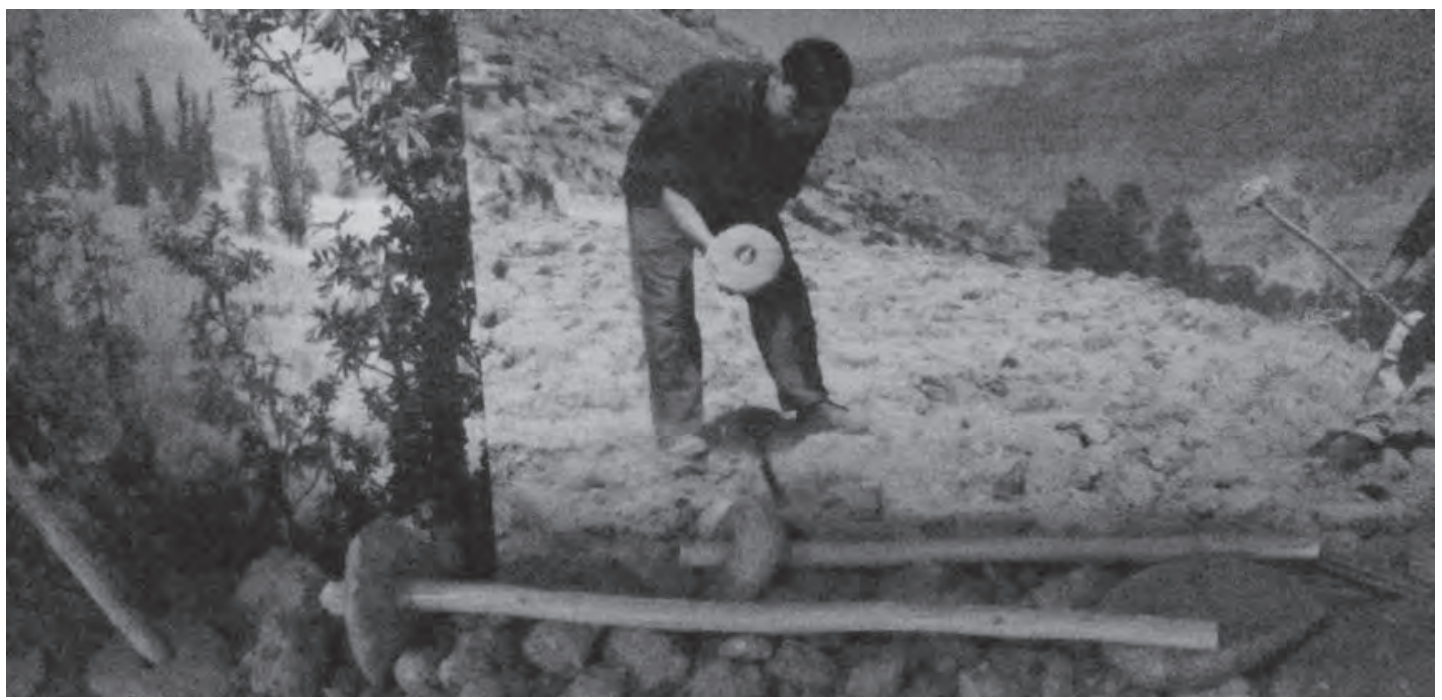

Figura 80. Vista de las Wuanash expuestas en el museo del distrito de Huaricolca, provincia de Tarma. 


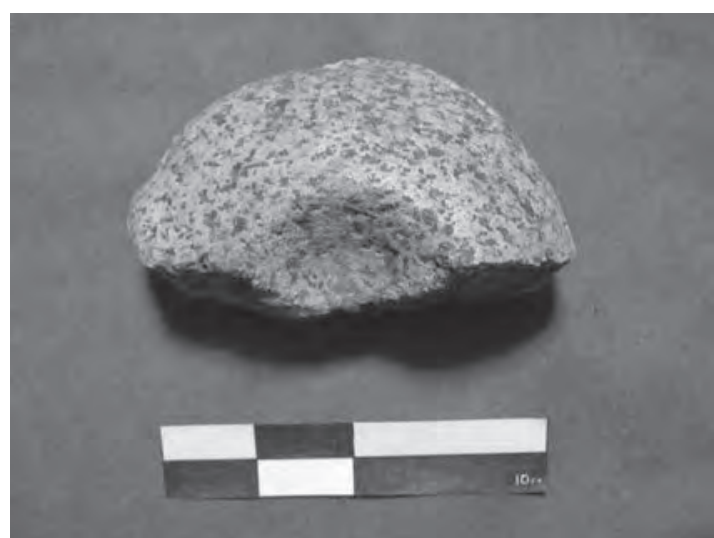

Figura 81. Vista de la Wuanash hallada por nosotros en la Cuadrícula 15 de nuestras excavaciones arqueológicas en Anjushmarca.

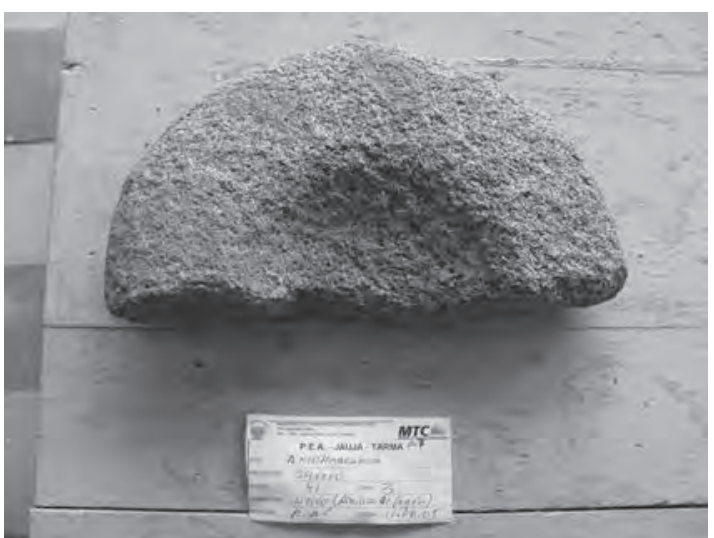

Figura 82. Vista de la Wuanash hallada durante el PEA realizado para la pavimentación de la carretera Jauja-Tarma.

\section{DiSCUSIÓN SOBRE LA ORGANIZACIÓN SOCIAL DE LOS GUANCAS Y TARAMAS, EN RELACIÓN AL DATO ARQUEOLÓGICO}

Sobre la organización social de los guancas y taramas se ha dicho poco hasta el momento. Siendo el grupo de investigaciones UMARP (Earle 1978, 1987, 2001), uno de los primeros en proponer un tipo de organización social guanca en base a datos arqueológicos. Este grupo realizó sus investigaciones en el sitio de Tunanmarca, Umpamalca y Hatunmarca, y además en las regiones de Yanamarca y la laguna de Paca. UMARP (Earle 1978, 1987, 2001) propuso que la organización social guanca estuvo regida por un sistema de Jefaturas, en el cual la élite dominante regía los aspectos económicos, religiosos y sociales.

UMARP (Earle 1978, 1987, 2001) propuso que en Tunanmarca habitó una élite guanca, ellos mencionan que esta supuesta élite habito en los recintos habitacionales que presentan aparejos armoniosos tipo mosaiqueria y que se encuentran en la zona central de Tunanmarca. Mientras que la población común ocupo los edificios habitacionales que presentan aparejos rústicos y que se ubican en las áreas periféricas de Tunanmarca. Además UMARP (Earle 1978, 1987, 2001) menciona que en las excavaciones arqueológicas en Tunanmarca, realizadas dentro de los edificios habitacionales de la supuesta élite, se halló material arqueológico que correspondería a este tipo de clase social. Mientras que en las excavaciones realizadas dentro de los edificios habitacionales de la población común, se encontró evidencia de ocupación domestica correspondiente a este tipo de clase social popular.

Analizando las publicaciones que realizo el grupo UMARP (Earle 1978, 1987, 2001) y sus miembros por separado a lo largo de estos años, observamos que los datos expuestos por ellos no apoyan el postulado de una sociedad guanca regida por una Jefatura. El dato arquitectónico, del cual se basan para hacer una diferencia social, no es muy claro. Pues ellos se enfocan en las diferencias arquitectónicas de los aparejos de los recintos habitacionales. Pero durante nuestra investigación hemos podido observar que en el sitio de Muqui en Muillaullos-Jauja, aún los recintos habitacionales conservan el enlucido es sus paramentos. Lo cual nos indica que estos edificios guancas estuvieron enlucidos con arcilla calcárea, el mismo que es usado como mortero. Por lo tanto, se infiere que los aparejos de los edificios habitacionales, en su momento de ocupación original se encontraban totalmente enlucidos. Este dato nos lleva definir que las diferencias entre los aparejos no serían necesariamente por motivos de distinción de clases sociales, sino una clara diferencia arquitectónica producida por distintos momentos constructivos que tuvieron los guancas.

En Anjushmarca también hemos podido identificar edificios habitacionales que muestran aparejos similares a los que se observan en Tunanmarca. En Anjushmarca identificamos dos tipos de apare- 
jos en los edificios habitacionales, el primero muestra un aparejo con acabado aglutinado y un poco desordenado. Este aparejo es similar a los que se observan en las áreas que rodean la zona central de Tunanmarca. Pero en Anjushmarca, los edificios con este tipo de aparejos los encontramos en las zonas centrales de la Colina I y II. El segundo tipo de aparejo que hallamos en Anjushmarca muestra un mejor acabado, con un estilo de mosaiquería muy armonioso, estos edificios que muestran estas características se encuentran en la zona oeste de la Colina II.

Nosotros analizando este punto hemos podido reafirmar que el motivo de la existencia de estos dos tipos de aparejos, en los edificios habitacionales guancas, se debería a un motivo de momentos constructivos. Pues en Anjushmarca hemos identificado dos fases constructivas, las cuales también se habría dado en Tunanmarca. En Anjushmarca hemos determinado que el primer momento constructivo se caracteriza por presentar edificios con los aparejos un poco toscos y con la disposición de las piedras aglutinadas, estos edificios los ubicamos en las zonas centrales de las Colina I y II de Anjushmarca, pues en un primer momento constructivo la población de este sitio ocupó estas áreas. Mientras que el segundo momento constructivo de caracteriza por presentar edificios con los aparejos muy elaborados en estilo de mosaiqueria, estos edificios se concentran en la zona oeste de Anjushmarca, pues para ese tiempo las áreas centrales de Anjushmarca ya estarían ocupadas, dejando libre la zona oeste de la Colina II del sitio, concentrándose en esta zona las nuevas edificaciones del segundo momento constructivo (Navarro 2012).

Este análisis arquitectónico y espacial, nos determina que las diferencias constructivas entre los edificios guancas, no se dieron para distinguir a un tipo de clase social. Estas diferencias constructivas se produjeron a causa de dos momentos constructivos. En los cuales, cada momento o fase constructiva se caracterizó por presentar un tipo de aparejo en los edificios. Es evidente que a medida que pasó el tiempo, las técnicas constructivas de una sociedad evolucionan generándose edificios más estables y tecnificados que muestran detalles propios.

Analizando los hallazgos que realizó UMARP (Earle 1978, 1987, 2001) durante sus excavaciones arqueológicas en Tunanmarca, hemos podido observar que no existe una clara diferencia entre el material hallado dentro de los edificios habitacionales de la supuesta élite y de la población común. Pues los cuadros estadísticos y los datos que han publicado UMARP y sus miembros (Earle 1978, 1987, 2001), no ayudan a sustentar la existencia de una élite, pues no se identifican claros datos arqueológicos que comprueben la existencia de una élite Guanca, la cual se distingan de la población común. En las últimas publicaciones que realizaron los miembros de UMARP (Earle 2001), han aceptado, en cierta medida, que sus datos no ayudan a sustentar la teoría de una organización social Guanca regida por una Jefatura dominante. Ahora ellos postulan que no hubo una Jefatura rígida sino más blanda, la cual gobernó a la sociedad Guanca. Los miembros de UMARP (Earle 2001) aun intentan mantener de uno u otra forma su postura, aun que ya sabemos que los datos arqueológicos no apoyan sus teorías.

Toda la evidencia arqueológica Guanca que hemos estudiado, nos permite afirmar que la propuesta de Jefatura, adoptada por UMARP para explicar el desarrollo social guanca, está equivocada, pues el dato arqueológico no ayuda a sustentar esta propuesta. La evidencia que nosotros hallamos en Anjushmarca y el material descubierto por UMARP (Earle 1978, 1987, 2001) en Tunanmraca, fortalece nuestra crítica hacia la teoría de Jefatura Guanca, pues no se hallaron evidencias arqueológicas que sean propias de la élite o claros contextos funerarios de esta clase social; pues para poder sustentar acertadamente que los guancas se organizaron en un modelo de Jefatura, es muy importante hallar la clara evidencia de la existencia de clase social dominante. Contrario a todo este supuesto, los datos arqueológicos registrados en Anjushmarca y Tunanmarca nos indican que la sociedad Guanca fue homogénea, sin la presencia de algún tipo de élite.

La investigación de UMARP (Earle 1978, 1987, 2001) nos demuestra que ellos iniciaron sus trabajos con el objetivo de implantar el modelo de jefaturas en los guancas, tratando de que el material arqueológico encaje en su teoría ya predeterminada, y no dejando expresar la información que transmitían sus 
hallazgos y reconocimientos arquitectónicos. Esto último es algo que no se debe realizar durante una investigación arqueológica, pues se debe respetar la evidencia arqueológica y no trasformar información según la conveniencia del investigador. Además, por último, el modelo de jefatura fue una propuesta planteada por Service (1984) para comprender el desarrollo evolutivo de las sociedades; el modelo de bandas, tribus, jefaturas y estado fue elaborado en base a datos antropológicos. Por lo cual siempre ha existido una crítica hacia este modelo por parte de los arqueólogos y en especial en el punto de las jefaturas, pues el dato arqueológico no siempre concuerda con el concepto de jefaturas. Por este motivo algunos arqueólogos en su intento de encajar a una sociedad en el modelo evolutivo de Service (1984) han trasformado el dato empírico. Hasta el momento no se han podido establecer normas globales y fijas para determinar cuáles son los datos arqueológicos que deben existir para establecer la existencia de una jefatura. Y en nuestro caso, durante nuestras investigaciones, no hallamos evidencia arqueológica que nos confirme la existencia de una jefatura guanca. Pues si UMARP habría encontrado la presencia de una élite en Tunanmarca, esta también debería haber existido en Anjushmarca, lo cual no pasó.

Nosotros, al concluir con toda esta investigación, proponemos que los guancas se organizaron en un sistema colectivo, en el cual se reunían los sinchis de cada ayllu y los personajes más representativos de los asentamientos, como valerosos guerreros y ancianos. En esta reunión colectiva se discutirían temas de disputas internas o externas que tuvieran los ayllus dentro del asentamiento o fuera de este, también verían el tema de la repartición de tierras para el cultivo y pastoreo (Navarro 2012). Y además, en esta reunión podrían formar pactos de trabajos entre ayllus para aumentar su producción y decidir acciones conjuntas sobre el futuro del asentamiento.

Como ya sabemos los guancas nunca lograron ser una sociedad totalmente unificada. Los guancas eran un conjunto de ayllus que compartían los mismos aspectos culturales, como la alfarería, textilería, orfebrería, religión y las mismas técnicas agrícolas y ganaderas. Nosotros proponemos que cada asentamiento guanca habría sido autónomo y organizado en un sistema colectivo, como ya lo explicamos líneas arriba. Una de las causas del porque los guancas nunca lograron ser unificados, sería por las disputas que habrían tenido por las tierras de cultivo y pastoreo, los cuales son muy importantes para desarrollar las actividades agropecuarias.

La organización social tarama, como ya mencionamos, es un punto que aún debemos estudiar más a fondo. Pero teniendo conocimiento de la situación guanca, podemos inferir algunas ideas preliminares. Como hemos visto hasta el momento, existen algunas similitudes entre el dato arqueológico guanca y tarama, ya sea en la producción agropecuaria y en la disposición de sus asentamientos. En base a esta evidencia, proponemos como hipótesis, que la sociedad tarama también habría estado organizada en un sistema colectivo, similar al guanca. Los taramas como productores agropecuarios también habrían tenido problemas para delimitar las tierras de cultivo y pastoreo entre sus ayllus, estos conflictos se habrían resuelto dentro del sistema colectivo; dentro de esta reunión colectiva también se resolverían los conflictos que se producirían entre los ayllus. Este sistema colectivo tarama también estaría integrado por los sinchis de los ayllus y por los personajes influyentes de los asentamientos.

Dentro de este sistema de organización social guanca y tarama, los ayllus se destacarían entre los demás por el nivel de producción que podrían desarrollar. Pues si un ayllu poseía mas fuerza de trabajo, abarcaría más actividades económicas y así destacarse entre los demás ayllus con menor producción o fuerza de trabajo. Esta variante de fuerza de trabajo que produciría cada ayllu, sería el aspecto distintivo entre los ayllus de un asentamiento. Pues el dato arqueológico que hemos analizado, nos ha demostrado que los ayllus guancas y taramas tuvieron como función principal el desarrollo de actividades productivas como la ganadería, agricultura, alfarería, textilería y orfebrería. 


\section{DisCUSIÓN SOBRE EL DESARROLLO AGRÍCOLA Y GANADERO DE LOS GUANCAS Y TARAMAS: NUEVAS PERSPECTIVAS}

Las prospecciones arqueológicas, el análisis de los recursos naturales que se asocian a los sitios guancas y taramas, y los hallazgos realizados durante las excavaciones arqueológicas en Anjushmarca, nos han revelado importantes datos sobre el desarrollo agrícola y ganadero de estas culturas centroandinas.

Como ya hemos expuesto en el punto de las prospecciones arqueológicas, los asentamientos guancas y taramas se encuentran directamente asociadas a tierras de cultivo, ya sea en las zonas de puna o quechua. Lo cual nos demuestra que los guancas y taramas tuvieron un total manejo de la producción agrícola, aprovechando los distintos pisos ecológicos, lo cual les ayudó a obtener una variada producción agrícola. Llegando a producir en la región quechua productos como el maíz, la papa, la quinua, el ají y frutos como el tumbo y la guinda. Mientras que en las tierras de cultivo de la región puna cultivaron la maca, la papa, la oca, la mashua, el olluco y frutos como el wahuro (Navarro 2012).

Durante la investigación arqueológica en Anjushmarca hemos podido registrar muestras de chancadores de tierra o Wuanash, el cual es un instrumento lítico esencial para el arado de la tierra. Como Anjushmarca es un asentamiento ubicado en la puna, estos hallazgos nos confirman que los pobladores guancas de puna contaron con óptimas herramientas para practicar la agricultura. Esta evidencia nos permite inferir que este tipo de instrumento lítico, usado en el arado de la tierra, no sólo habría sido utilizado por los guancas ubicados en la puna, sino también por los guancas ubicados en las zonas quechua de valles y quebradas. Además los taramas también utilizaron esta herramienta lítica para el arado de la tierra, pues en Yuracmarca también hallamos una Wuanash en superficie, lo cual nos indica que los pobladores taramas si contaron con este instrumento (Navarro 2012).

El óptimo manejo de los pisos ecológicos por parte de los agricultores guancas y taramas, fue gracias a la geografía que presenta esta región de los Andes centrales, la cual se caracteriza por presentar valles, quebradas y punas. El desarrollo agrícola en estas zonas ayudo a generar muchos productos agrícolas. En conclusión los guancas y taramas desarrollaron actividades agrícolas en las regiones quechua y puna sin dificultad alguna.

Analizando los asentamientos guancas y taramas, que se encuentran asociados a tierras de cultivo de regiones quechua y puna, observamos que estos también presentan amplios corrales. La presencia de estos corrales indica que los pobladores de estos asentamientos también tuvieron un dominio provechoso sobre la ganadería de camélidos. Los asentamientos que hemos expuesto en este trabajo, cuentan con numerosos corrales, esto nos indican que la población guanca y tarama supo desarrollar la ganadería en las regiones quechua y puna.

Estas culturas aprovecharon los corrales para generar una optima producción ganadera, pues contar con muchos y espaciosos corrales ayudan a separar a los animales enfermos de los sanos, a tener un mejor control sobre los cruces, a poder cuidar a las hembras preñadas de los machos para evitar abortos, también ayudan a separar a los camélidos jóvenes de los adultos y a tener un mejor control productivo sobre el ganado.

Toda la evidencia arqueológica expuesta, nos indica que en los asentamientos guancas y taramas se desarrollaron óptimas actividades agropecuarias. Los datos nos confirman que en estos asentamientos se produjo la agricultura y la ganadería al mismo tiempo, lo cual afirma que los pobladores guancas y taramas se beneficiaron de las tierras de cultivo ubicadas en las regiones de puna y quechua, además aprovecharon los pastizales y bofedales de las punas para desarrollar la ganadería. Si bien los pastores de los sitios ubicados en la región puna tenían más ventaja en practicar la ganadería, por tener fácil acceso a los pastizales y bofedales, los pastores de las regiones quechua también desarrollaron la ganadería. Pues hemos registrado sitios como Chaquimarca, Tunanmarca y Coto Coto que presentan corrales y que se ubican en plena región quechua. Estos datos nos indican que los pastores 
de las regiones quechua se trasladaron arreando su ganado hasta las áreas de puna más cercanas para aprovechar los pastizales y bofedales, para luego regresar a sus asentamientos. Además estos pastores también habrían construido estancias temporales para aprovechar los recursos de la puna por más tiempo.

La evidencia arqueológica que registramos, nos lleva a realizar una crítica hacia la teoría que ha desarrollado Parsons $(1978,2000,2004)$ para explicar el desarrollo productivo de la región Tarama en los Andes centrales. Parsons $(1978,2000,2004)$ propone que en la región de la puna solo se habría desarrollado la ganadería, mientras que en la región quechua la agricultura, y que entre estos dos tipos de asentamientos hubo una interacción para poder obtener los recursos que les hicieran falta entre sí, agrupándolos en dos o tres asentamientos para inferir lazos de interacción según su cercanía geográfica y teniendo las ideas de dualidad y tripartición andina.

Nosotros analizamos esta propuesta en relación a nuestros datos arqueológicos, podemos decir que la propuesta de Parsons limita el potencial productivo de los pobladores de los Andes centrales. Pues la evidencia que presentamos en este trabajo nos demuestra que los taramas y guancas desarrollaron actividades agropecuarias sin importar su ubicación geográfica, ya sea en la zona de puna o quechua. Los sitios arqueológicos que hemos presentado se caracterizan por ubicarse entre los $3600 \mathrm{y}$ 4300 msnm y por presentar evidencias claras de haber desarrollado actividades agrícolas y ganaderas sin presentar limitación por su ubicación geográfica.

En este trabajo estamos demostrando que la teoría propuesta por Parsons $(1978,2000,2004)$ está equivocada. Pues Parsons no realizó un buen estudio en el marco de la teoría de la Ecología Cultural que él adoptó, ya que no analizó bien el entorno inmediato y no reconoció el total de los recursos naturales que se relacionaban con los asentamientos. Además no estudió la tecnología que tuvieron estas culturas pre-Tawantinsuyo, lo cual es un paso fundamental en la teoría de la Ecología Cultural. Nosotros si analizamos el aspecto tecnológico que los pobladores guancas y taramas, y realizamos un mejor análisis de los recursos naturales que tuvieron estos pobladores. Lo cual nos llevo a realizar un estudio más completo sobre el desarrollo productivo en los Andes centrales. Demostrando que los asentamientos ubicados en la puna no solo desarrollaron la ganadería sino también la agricultura y que en los asentamientos ubicados en la región quechua no solo se dedicaron al agro sino también a la ganadería.

En este punto también debemos mencionar una crítica hacia la teoría económica que propuso el grupo de investigaciones UMARP (Earle 1978, 1987, 2001), para comprender el desarrollo económico Guanca. Ellos en el marco de su teoría de Jefaturas exponen que la economía de esta cultura fue especializada. UMARP (Earle 1978, 1987, 2001) menciona que hubo trabajos especializados individuales, grupales y de asentamientos; además ellos indican que estos trabajos especializados estuvieron dirigidos por una supuesta élite gobernante. En sus publicaciones ellos afirman que Tunanmarca fue un sitio especializado en la producción agrícola y que en Umpamalca se desarrolló la alfarería, en un claro ejemplo de su propuesta de trabajos especializados. Y también mencionan que cada ayllu se dedicaría a una actividad económica especializada.

Los datos que pudimos registrar durante las prospecciones arqueológicas y en especial en las excavaciones arqueológicas en Anjushmarca, nos indican que los ayllus guancas y taramas tuvieron una economía multiproductiva. Pues en la Cuadricula 1, 2, 3 y 4 de nuestras excavaciones en Anjushmarca hallamos material domestico asociado a instrumentos textiles como una wichuña y un piruro, además esta zona se encuentra directamente asociado a la zona de los corrales. Con estos datos podemos inferir que los ayllus que habitaron esta área se dedicaron a múltiples actividades productivas. En la Colina II de Anjushmarca, en la cuadricula 12, 13 y 15, hallamos material domestico, instrumentos agrícolas y restos óseos de camélidos calcinados. Lo cual nos determina que los ayllus de esta zona se dedicaron a la ganadería y agricultura, como también a desarrollar actividades domesticas, lo cual requiere de un esfuerzo por parte de los miembros del ayllu (Navarro 2012). 
Los datos arqueológicos de las prospecciones y de los contextos cerrados de Anjushmarca, nos indican que estos ayllus guancas y taramas realizaron diversas actividades productivas, nosotros inferimos que la fuerza de trabajo que poseía cada ayllu habría sido la variante para poder realizar más o menos actividades económicas, demostrando que la fuerza de trabajo de los ayllus fue muy determinante para el crecimientos de estas organizaciones familiares.

\section{ANÁLISIS SOBRE LA ACTIVIDAD FUNERARIA DE LOS GUANCAS Y TARAMAS}

La evidencia arqueológica analizada, nos demuestra que los guancas y taramas tuvieron tres tipos de manifestaciones funerarias. La primera se produjo edificando edificios funerarios de planta circular, cuadrangular y rectangular, los cuales presentan hasta tres niveles y pueden llegar a medir tres metros de alto. Además estos edificios presentan ventanales cuadrangulares y semitrapezoidales en cada nivel. En este grupo también integramos a los osarios, los cuales son edificios de planta rectangular de una cavidad sellada. La segunda expresión funeraria se produjo en las cercanías de pronunciadas afloraciones rocosas, peñascos y cavernas. Al pie de estas formaciones geológicas hemos identificado cámaras funerarias, las cuales fueron elaboradas tallando la roca madre y aprovechando la propia formación rocosa, en estas cámaras se depositaban a los muertos, estas cámaras eran selladas con muros roca y arcilla calcárea. La tercera acción funeraria se produjo en las murallas perimetrales de los asentamientos, en este caso los edificios y pequeñas cámaras funerarias se encuentran adosadas a las murallas perimetrales, siempre ubicándose en la zona interna del asentamiento y sus ventanas se orientan hacia el interior de los sitios. Hasta el momento solo hemos podido observar esta manifestación funeraria en los asentamientos Tarama.

Una de las preguntas que nos realizamos al analizar la actividad funeraria de estas dos culturas es ¿Cuál de estas tres expresiones funerarias tuvo mayor relevancia entre la sociedad guanca y tarama? ○ ¿Cuál es el orden cronológico de estas manifestaciones funerarias?.

Para responder estas dos preguntas es necesario conocer cuáles fueron las pacarinas sagradas de los guancas y taramas. Para ello indagamos datos etnohistóricos, los cuales relacionamos con el dato arqueológico que registramos durante nuestra investigación.

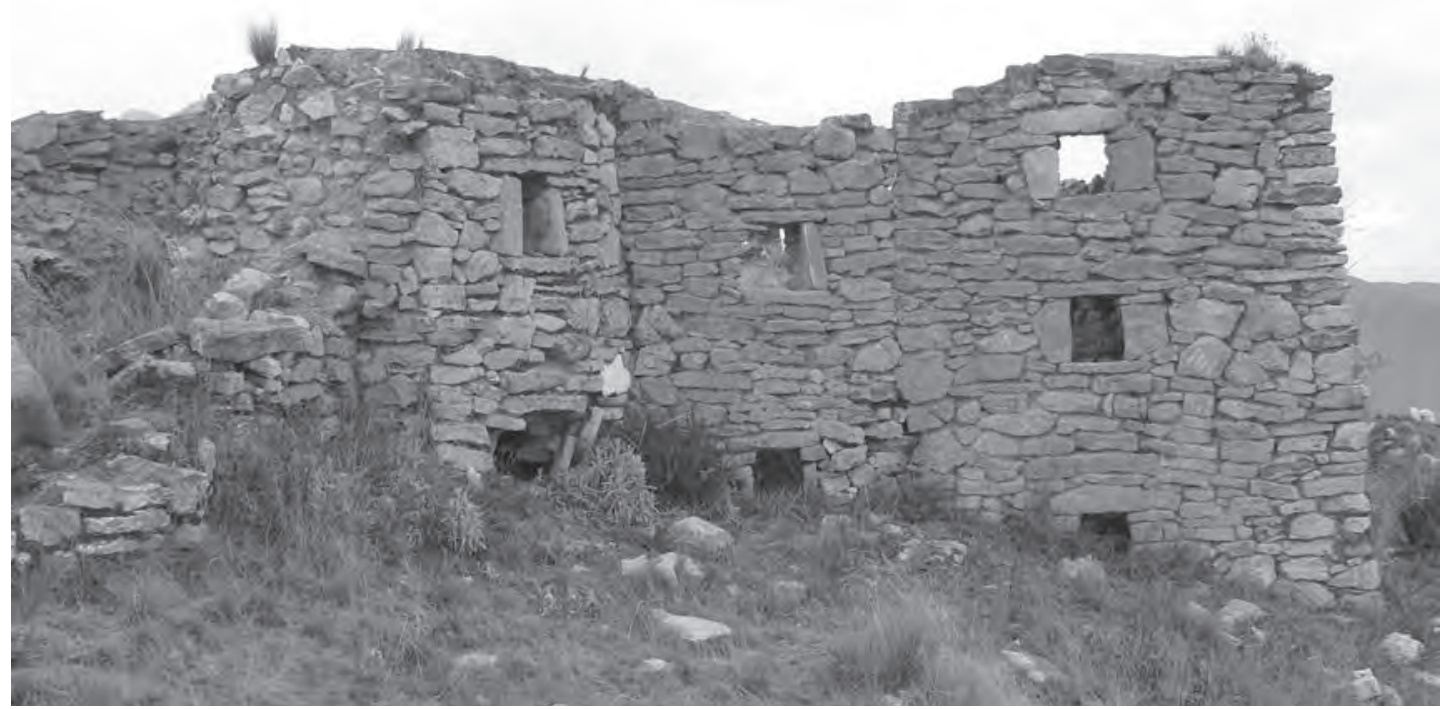

Figura 83. Vista de los 3 edificios funerarios asociados a un patio en el sitio de Yanamarca. Ubicado en el Distrito de Acobamba en la Provincia de Tarma. 
Analizando las leyendas registradas sobre el origen de los guancas, contadas por Cieza de León (1973) y Navarro del Águila (1983), hemos observado que los ellos tuvieron como pacarinas a los afluentes de agua y lagunas. Cieza de León (1973) relata que los guancas surgieron del puquial del templo de Warivilca; mientras que en el relato registrado por Navarro del Águila (1983) se indica que el hombre que dio origen a los guancas surgió del lago Choklococha, en la actual región de Huancavelica.

Los datos arqueológicos expuestos en este trabajo nos demuestran que las formaciones rocosas, como farallones, peñascos y cavernas, fueron consideradas como pacarinas por los guancas y taramas, pues existe mucha evidencia funeraria asociada a estas formaciones geológicas. Esto nos permite interpretar que los guancas y taramas al morir desearon regresar a su pacarina, con la idea de regresar a su lugar de origen sobrenatural. Por este motivo los edificios funerarios y los depósitos de muertos se encuentran directamente asociados a estas caprichosas formaciones rocosas.

En referencia a la primera pregunta hecha sobre el aspecto funerario guanca y tarama. Nosotros interpretamos que las manifestaciones funerarias directamente asociadas a las formaciones rocosas, habrían sido zonas privilegiadas solo para los personajes más destacados de los sentamientos, como para los valerosos guerreros, sabios importantes o notables sinchis de los ayllus. Mientras que en los edificios funerarios de planta circular, semicuadrangular u osarios, habrían sido usados como mausoleos destinados para depositar a los restos funerarios de un ayllu en particular. En el sitio tarama de Yanamarca, ubicado en Acobamba, hemos registrado notables agrupaciones de dos o tres edificios funerario de planta semicuadrangular de dos y tres pisos de alto asociados a un patio. Estos datos nos ayudan afirmar que estos edificios funerarios fueron mausoleos destinados para cobijar a los miembros de un ayllu.

Sobre la segunda pregunta realizada, nosotros proponemos en base a un análisis arquitectónico realizado en Anjushmaca y en otros sitios guancas y taramas, que las edificaciones funerarias de base cuadrangular o semirectangular y pequeñas cámaras asociadas a formaciones geológicas, habrían sido edificadas con mas continuidad en la primera mitad del Intermedio Tardío; mientras que en la segunda mitad del Intermedio Tardío se iniciaría la construcción de los osarios y edificios funerarios de base circular. Aún nos falta registrar y estudiar mucha evidencia arqueológica sobre este punto, la cual nos ayude a realizar mejores interpretaciones sustentadas con datos empíricos.

El caso de las cámaras y edificios funerarios adosados a las murallas perimetrales en los asentamientos tarama, proponemos que estas edificaciones habrían sido construidas a inicios del Intermedio Tardío, pues nuestro análisis arquitectónico nos confirma esta cronología. En el tema de la ocupación de estos edificios, aun no podemos determinar bien qué tipo de personajes fueron depositados en estos edificios.

\section{Agradecimientos}

A la Universidad Nacional Mayor de San Marcos y a la Municipalidad Distrital de Huaricolca por ayudarnos a concretar el convenio de cooperación, con el cual pudimos realizar nuestras excavaciones arqueológicas en el sitio Anjushmarca. A mis padres por todo el apoyo que me han brindado para continuar con la investigación arqueológica. Agradezco a mis compañeros Jorge Alonso Rodríguez, José Antonio Guerrero, Jhustye Domínguez y Nelly Flores por su apoyo incondicional durante nuestro trabajo de campo.

\section{BiBLIOGRAFÍA}

ALTAMIRANO, Alfredo

1987 «Desarrollo dentario de los camélidos sudamericanos». Boletín de Lima 46: 9-16. Lima.

1989 La planimetría del centro administrativo Inca de Hatun Xauxa, Informe preliminar. Consejo Nacional de Ciencia y Tecnología (CONCYTEC). Lima.

ALTAMIRANO, Alfredo; Víctor PACHECO y Enma GUERRA

1986 The Osteology of South American Camelids. Archaeological Research Tools Vol. 3. Los Ángeles: Institute of Archaeology, University of California. 
CALDERÓN, Manuel

2009 Cashamarca: Su ubicación dentro del proceso histórico del Antiguo Perú. Cemento Andino. Perú.

CIEZA DE LEÓN, Pedro

1967 El Señorío de los Incas. (2º parte de la Crónica del Perú). Lima: Instituto de Estudios Peruanos (IEP).

1973 La Crónica del Perú, Lima: Peisa.

EARLE ,Timothy

2001 «Exchange and Social Stratification in the Andes: The Xauxa Case». En: T.D'Altroy y C. Hastorf (eds.) Empire and Domestic Economy, pp. 116-152. New York: Kluwer Academic / Plenum Publishers.

EARLE, Timothy, Terence D’ALTROY y Catherine LeBLANC

1978 «Arqueología regional de los periodos prehispánicos Tardíos en el valle del Mantaro». En: R. Matos (ed.) III Congreso Peruano: El Hombre y la Cultura Andina Tomo II: 641-672.

EARLE ,T., T. D'ALTROY, C. HASTORF, C. SCOTT, C. COSTIN, G. RUSELL y E. SANDEFUR

1987 Archaeological field research in the Upper Mantaro Valley, Peru: 1982-1983. Investigations of Inka Expansion and Exchange. Monograph 28. Los Ángeles: Institute of Archaeology, University of California at Los Angeles.

MALLMA, Arturo

2004 Introducción a la Arqueología e Historia de los Xauxas Wankas. Lima: Biblioteca Nacional del Perú.

MATOS, Ramiro

1959 Los Wankas: datos históricos y arqueológicos. En: Actas y Trabajos del II Congreso Nacional de Historia del Perú: Época Prehispánica Vol. 2: 187-210. Lima: Centro de Estudios Históricos-Militares del Perú.

MORALES, Daniel

1977 Investigaciones arqueológicas en las salinas de San Blas (Junín) y sus implicaciones en el periodo formativo en la sierra central del Perú. Tesis para optar el grado de Bachiller, UNMSM. Lima.

NAVARRO DEL ÁGUILA, Víctor

1983 Las tribus de Ansku Wallock. Lima: Ediciones Atusparia.

NAVARRO, Irvin

2012 Desarrollo Económico y Social de los guancas: Caso Anjushmarca. Tesis de Licenciatura. Universidad Nacional Mayor de San Marcos. Lima.

ORELLANA, Simeón

1973 «Huacjlasmarca, un pequeño poblado Huanca». En: Anales Científicos de la Universidad Nacional del Centro del Perú 2: 69-132. Huancayo.

PARSONS, Jeffrey y Ramiro MATOS

1978 «Asentamientos prehispánicos en el Mantaro, Perú. Informe preliminar». En: R. matos (ed.) III Congreso Peruano: El Hombre y la Cultura andina Tomo II: 540-556. Lima.

PARSONS, Jeffrey; Charles HASTINGS y Ramiro MATOS

2000 Prehispanic Settlement Patters in the Upper Mantaro and Tarma Drainages, Junín, Peru. Volume I. The Tarama-Chinchaycocha Region, Part 2. Memoirs of the Museum of Anthorpology № 34. University of Michigan. Michigan.

2004 «Reconstruyendo el Estado en la sierra central del Perú. La interpretación entre pastores y agricultores durante el período intermedio tardío en la región de Tarama-Chinchaycocha». En: Investigaciones Sociales VIII(2): 55-98. Lima: Universidad Nacional Mayor de San Marcos.

PERALES, Manuel

2011 «Una aproximación al estudio de las sociedades prehispánicas tardías de Ricrán, Jauja. Períodos Intermedio Tardio (ca. 900-1470) y Horizonte Tardio (1470-1533)». En: Pueblos del Hatun Mayu. Historia, Arqueología y Antropología en el valle del Mantaro: pp. 9-52. Lima: Consejo Nacional de Ciencia y Tecnología.

1984 Los orígenes del Estado y de la civilización. Alianza Editorial. Madrid. 